\title{
Participatory Democracy in Porto Alegre and Belo Horizonte
}

Terence Wood 


\section{Participatory Democracy in Porto Alegre and Belo Horizonte}

Terence Wood

Victoria University of Wellington

Wellington, New Zealand

Contact: woodterence@yahoo.co.nz

Submitted in partial fulfilment of the

Master of Development Studies Degree

August, 2004 


\begin{abstract}
Participatory budgeting is a form of Participatory Democracy that is being increasingly used in Brazilian cities. This dissertation describes research conducted on the participatory budgets of two Brazilian cities, Porto Alegre and Belo Horizonte. The research was undertaken with the overall aim of examining and comparing the participatory budgeting experiences in these two cities and then using this examination to identify the key local variables that can influence the outcomes of participatory budgets. The research made use of both primary and secondary data sources. The primary data used the result of 22 semistructured interviews that took place in April and May 2004, and the secondary data was the already existing body of literature on participatory budgeting in Porto Alegre and Belo Horizonte. The key findings of this research are that participatory budgeting has had some significant successes in both Porto Alegre and Belo Horizonte. At the same time though the participatory budgets in Porto Alegre and Belo Horizonte have encountered problems that have limited their abilities to produce results. There are also several areas where the outcomes of participatory budgeting are, at present, unclear. Some of the outcomes of the participatory budgets in Porto Alegre and Belo Horizonte are very similar yet there were differences in the processes' results. Two key variables are identified in the analysis: the ability of the participatory budget to produce tangible results and the degree of need that a city's populace has for municipal services. Associated with these key variables are a range of secondary variables that also influence the outcomes of participatory budgets.
\end{abstract}




\section{Acknowledgements}

In New Zealand,

I would like to thank Vijay Naidu, my course co-ordinator, and Warwick Murray, my research supervisor, for their assistance with this project. I would also like to thank my parents for supporting me - again. And finally, I would like to thank Joanna Spratt for her helpful suggestions, meticulous proofreading and constant support.

In Brazil,

I would like to thank all my research participants for their time and assistance. In particular, I am grateful to Sergio Baierle and Alexandre Stolte for going out of their way to help me. I would also like to thank Ricardo Holtz, Magaly Pazello, and Nara Hirschland for their help and friendship. And I am most grateful to Rodrigo Valente Noronha and his family for taking me in and showing me true Minero hospitality.

And above all,

I want to thank Flávio Carvalho Brito, Yamil Dutra and Liseth Bacellar, without whose assistance this project would definitely not have been possible.

Although I am indebted to all of the people listed above, I want to stress that any errors or omissions in this dissertation are mine alone. 


\section{Contents}

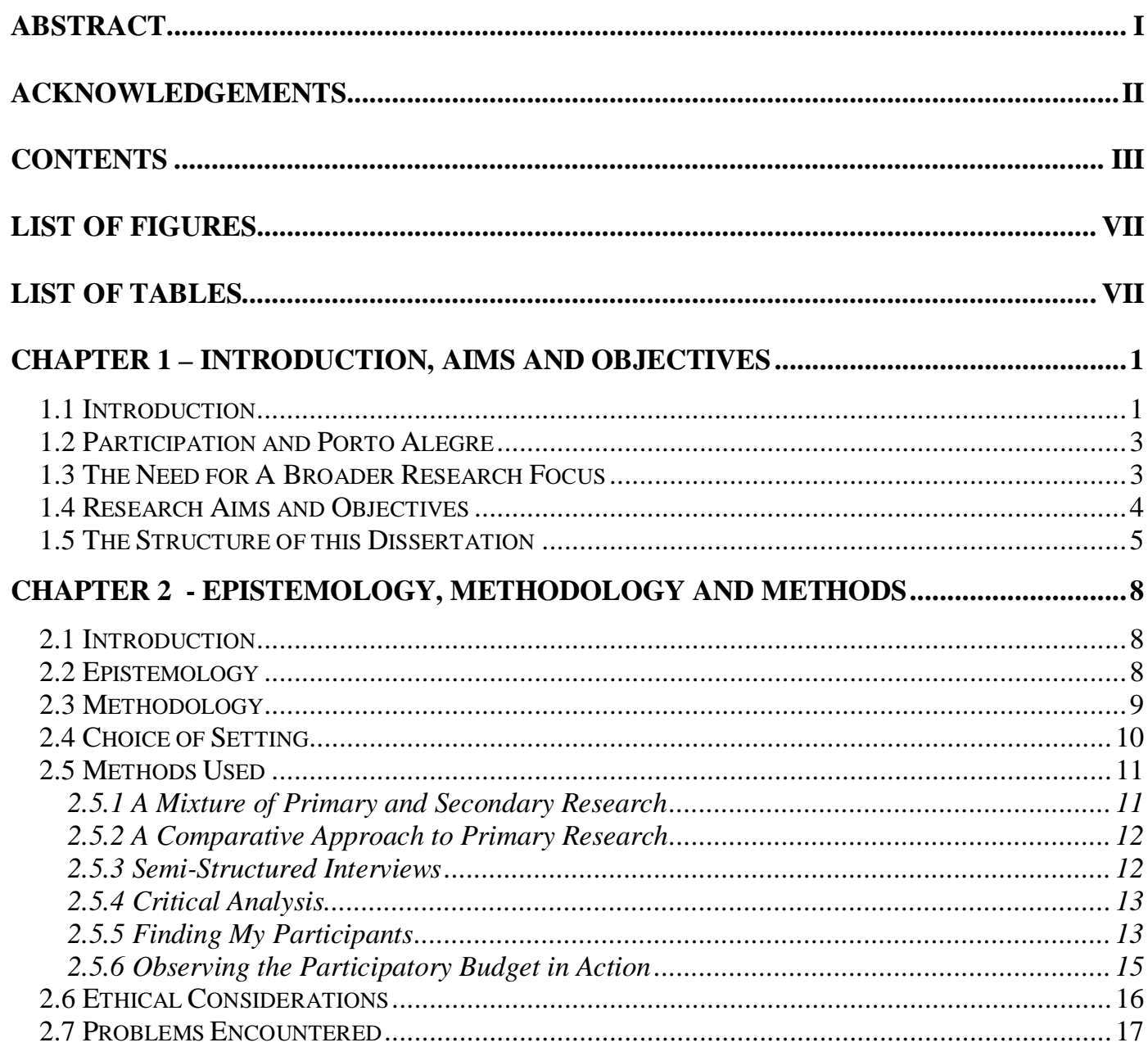

CHAPTER 3 - DEMOCRATIC THEORY AND PARTICIPATION .....................................20

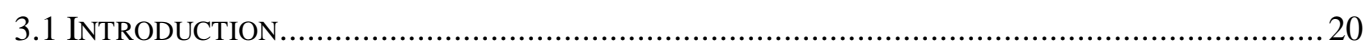

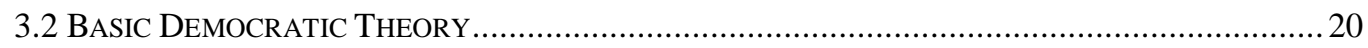

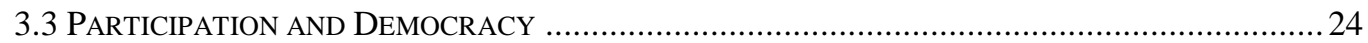

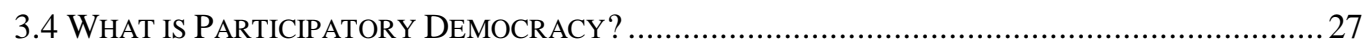

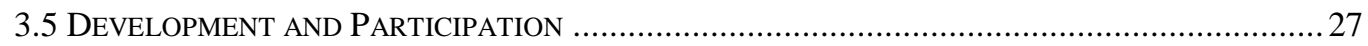

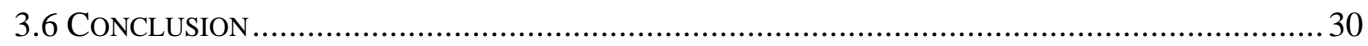

CHAPTER 4 - BRAZILIAN POLITICAL HISTORY ............................................................31

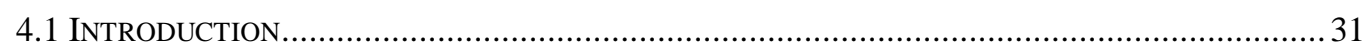

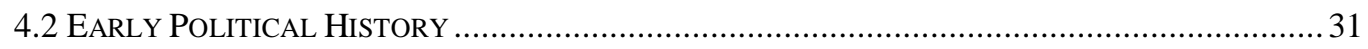

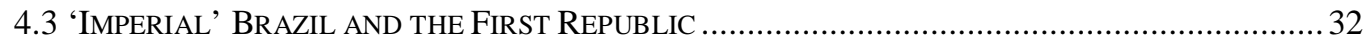

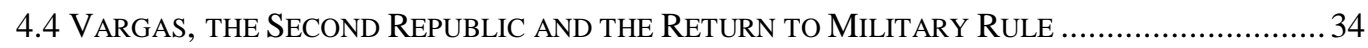

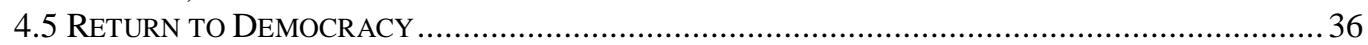

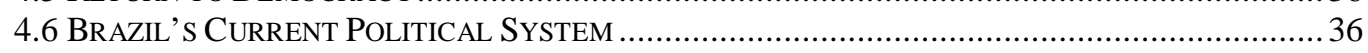

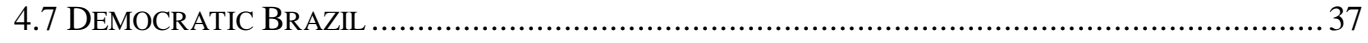

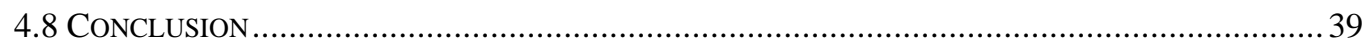

CHAPTER 5 - THE PT IN OPPOSITION AND IN POWER...............................................40

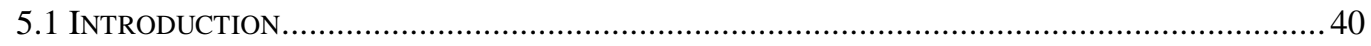

5.2 THE RISE AND RISE OF THE PARTIDO DOS TRABALHADORES ……..................................... 40

5.3 THE PT AND THE PROBLEMS OF MUNICIPAL GOVERNANCE ...................................................4 46

5.3.1 The PT's Inexperience in Municipal Government ...................................................... 47 
5.3.2 Divisions between Different Party Factions .... 47

5.3.3 The Gulf Existing between Expectations of Social Reform and what is Actually Possible 48

5.3.4 The Hostility of Local Elites to the PT .................................................................. 48

5.3.5 The Need to Form Political Coalitions........................................................................ 49

5.3.6 Hostility from State Governments ...................................................................... 49

5.3.7 Tensions with Municipal Workers ....................................................................... 49

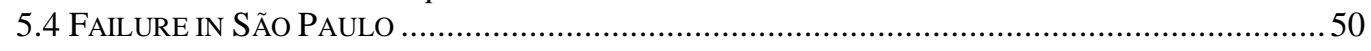

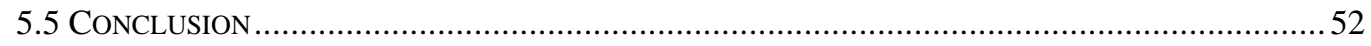

CHAPTER 6 - THE PARTICIPATORY BUDGET AND PORTO ALEGRE........................53

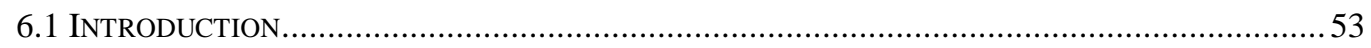

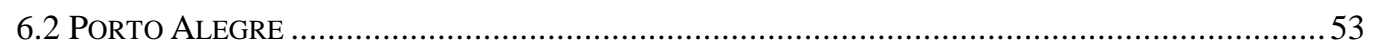

6.3 THE History OF PORTO ALEGRE ........................................................................... 56

6.4 The PT IN Porto Alegre....................................................................................... 57

6.5 THE PARTICIPATORY BUdGET - How IT FUnCTIONS........................................................59

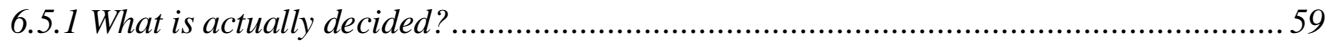

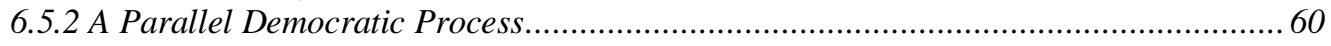

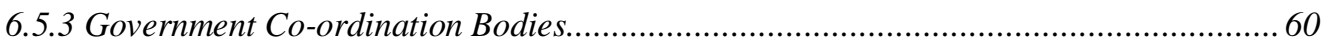

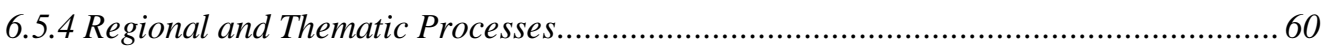

6.5.5 The Regional Assemblies and Budget Delegates................................................... 61

6.5.6 The Thematic Assemblies and Budget Delegates ..................................................... 62

6.5.7 Bringing it all together at the Budget Council ............................................................ 63

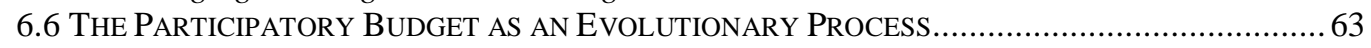

6.7 A Note on the Outcomes of the Participatory Budget in Porto Alegre................. 65

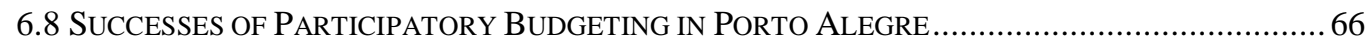

6.8.1 Provision of Municipal Services to the Previously Excluded....................................... 66

6.8.2 Opening a Space for the Political Participation of the Previously Excluded................. 68

6.8.3 Reduced Clientelism................................................................................................. 71

6.8.4 Reduced Corruption ............................................................................................... 72

6.8.5 Public Satisfaction ............................................................................................... 73

6.8.6 Keeping the PT in Power ....................................................................................... 73

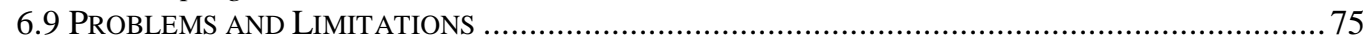

6.9.1 External Problem - Lack of Money ....................................................................... 75

6.9.2 External Problem - Resistance from Elites............................................................... 77

6.9.3 Internal and External Problem - Completing Works on Time ..................................... 78

6.9.4 Internal Problem - Lack of Technical Input and Centralised Planning ....................... 78

6.9.5 Internal Problem - Low Participation in Some Middle Class Neighbourhoods ............ 79

6.9.6 Problem/Limitation - Land Tenure ....................................................................... 79

6.9.7 Limitation - "Porto Alegre is Still a Third World City" .............................................. 80

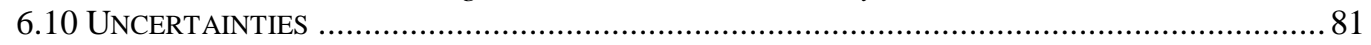

6.10.1 New Civic Activists and their Limitations......................................................... 81

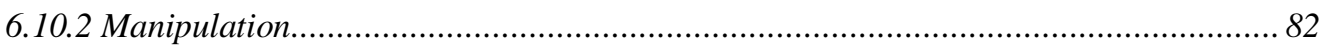

6.10.3 Civil Society: Weakened and Dependent? ........................................................ 84

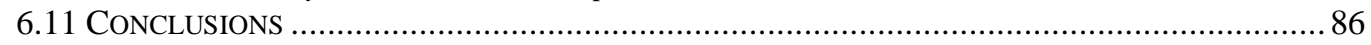

CHAPTER 7 - THE PARTICIPATORY BUDGET AND BELO HORIZONTE...................88

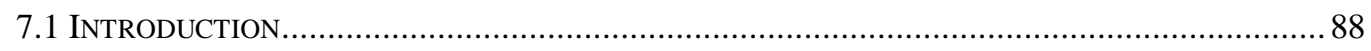

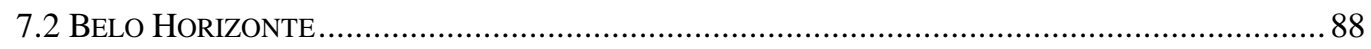

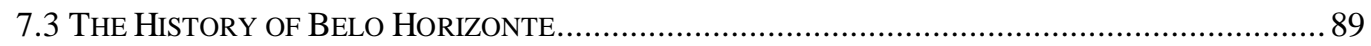

7.4 THE PT IN BELO HORIZONTE ................................................................................ 91

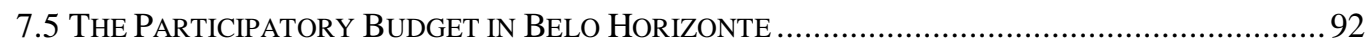

7.5.1 What is actually decided? .................................................................................... 92

7.5.2 A Parallel Democratic Process Held Every Two Years.......................................... 92

7.5.3 Government Co-ordination Body ........................................................................ 93

7.5.4 Regions, Sub-regions and two Rounds of Participation ............................................. 93

7.5.5 Incorporating the Middle class and the Marginalized............................................... 95

7.5.6 Parallel Participatory Processes ............................................................................. 96

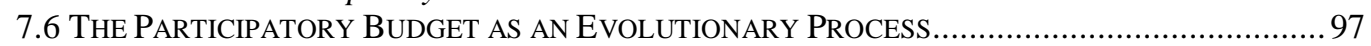

7.7 A Note on the Outcomes of the Participatory Budget in Belo Horizonte .............98 
7.8 SuCCESSES OF PARTICIPATORY Budgeting In Belo HorizonTE ...................................98

7.8.1 Provision of Municipal Services to the Previously Excluded....................................... 98

7.8.2 Opening a Space for the Political Participation of the Previously Excluded............... 100

7.8.3 Reduced Clientelism .................................................................................... 102

7.8.4 Reduced Corruption ............................................................................................... 103

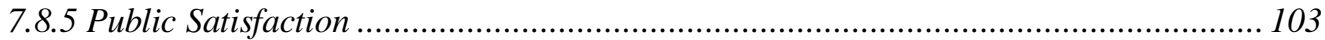

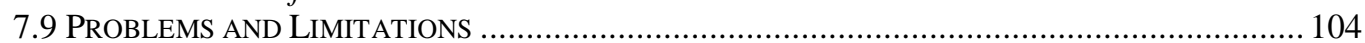

7.9.1 External Problem - Resistance from Government Departments............................. 104

7.9.2 External Problem - Resistance from Elites.............................................................. 104

7.9.3 Internal Problem - Inadequate Staffing Levels...................................................... 104

7.9.4 Internal and External Problem - Completing Works On Time ................................ 105

7.9.5 Internal Problem - Reaching the Sub-Poor and the Middle Classes......................... 106

7.9.6 Problem/Limitation - Land Tenure .................................................................... 108

7.9.7 Limitation - Belo Horizonte is Still a Third World City ........................................ 108

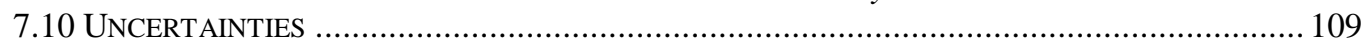

7.10.1 How Much Power is Really Divulged?................................................................ 109

7.10.2 Does the Caravan of Priorities Really Promote Altruism? ...................................... 110

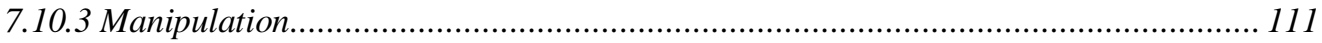

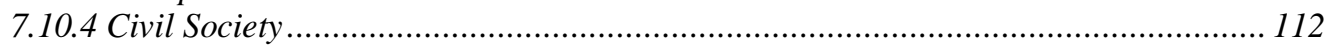

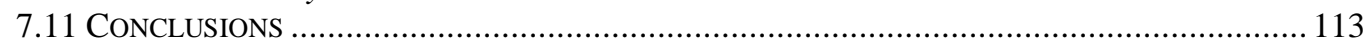

CHAPTER 8 - ANALYSIS, COMPARISON AND DISCUSSION.................................. 114

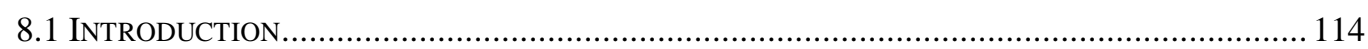

8.2 COMPARING THE CONTEXT .................................................................................. 114

8.3 COMPARING THE PROCESSES................................................................................. 116

8.4 COMPARING THE RESULTS .................................................................................. 117

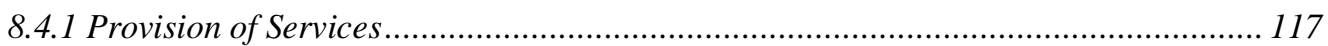

8.4.2 Participation ...................................................................................................... 117

8.4.3 Corruption and Clientelism ......................................................................... 118

8.4.4 Popularity ....................................................................................................... 118

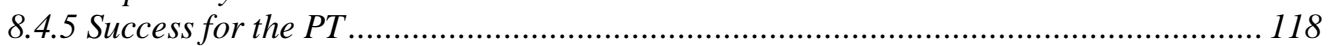

8.5 COMPARING THE PROBLEMS AND LiMITATIONS ........................................................ 119

8.5.1 Completing Works on Time ............................................................................... 119

8.5.2 Land-Ownership............................................................................................ 119

8.5.3 Resistance from Municipal Bureaucracy.............................................................. 119

8.5.4 Lack of Money for New Investments.................................................................... 120

8.5.5 Lack of Staff ........................................................................................................ 120

8.5.6 Lack of Technical Input and Centralised Planning ................................................ 120

8.5.7 Elite Resistance .................................................................................................... 121

8.5.8 Low Participation from Some Sectors of Society ................................................... 121

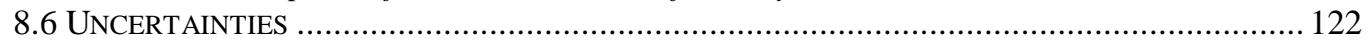

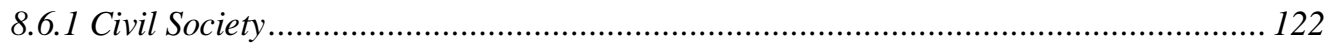

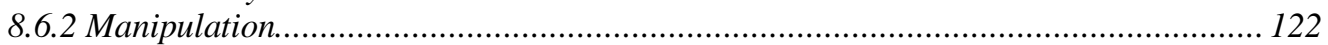

8.6.3 How Much Power is Really Divulged in Belo Horizonte? ..................................... 123

8.7 What has AfFECTED OutCOMES? ..................................................................... 123

8.7.1 People Having Needs ..................................................................................... 124

8.7.2 Factors that Influence the Level of People's Needs................................................... 124

8.7.3 Tangible Results......................................................................................... 125

8.7.4 Factors which Influence the Participatory Budget's Ability to Produce Tangible Results 126

8.8 Bringing IT ALl Together, How the VARiables Interact ...................................... 129

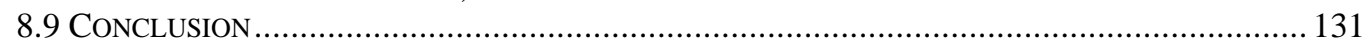

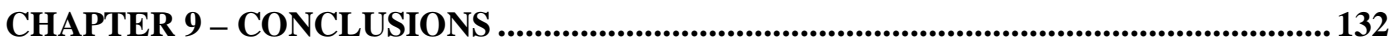

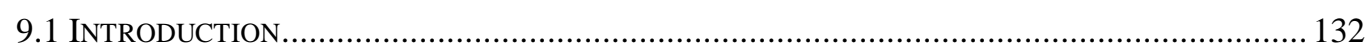

9.2 Successes, Problems and Limitations: Participatory Budgeting in Porto Alegre

AND BELO HORIZONTE ........................................................................................ 132

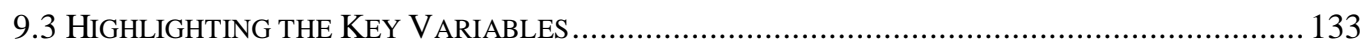

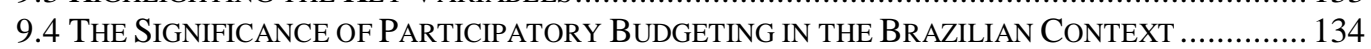


9.5 The SignificAnce of PARTICIPATORy Budgeting For DEMOCRATIC THEORY AND

DEVELOPMENT THEORY

9.6 THE LiMITATIONS OF THIS RESEARCH AND SUGGESTIONS FOR FUTURE RESEARCH

9.7 FINAL REMARKS.

APPENDIX 1 - ETHICS FORMS..

PARTICIPANT INFORMATION SHEET

PARTICIPANT CONSENT FORM

PARTICIPANT INFORMATION SHEET - IN PORTUGUESE .................................................... 147

PARTICIPANT CONSENT FORM - IN PORTUGUESE ..................................................... 148

CONFIDENTIALITY ClAUSE FOR ANY INTERPRETERS OR PEOPLE USED TO TRANSCRIBE TAPES OF THE INTERVIEW PROCESS 


\section{List of Figures}

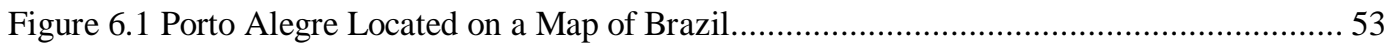

Figure 6.2 Conceptual Overview of the Participatory Budget in Porto Alegre ............................. 61

Figure 6.3 Participation in Regional and Thematic Assemblies, Porto Alegre ............................. 69

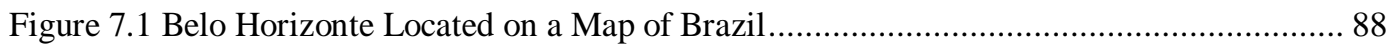

Figure 7.2 The Participatory Budget in Belo Horizonte ............................................................ 96

Figure 7.3 Number of Participatory Budget Participants in Belo Horizonte .............................. 101

Figure 8.1 Interaction of Key Variables in Participatory Budgeting Process ............................. 130

\section{List of Tables}

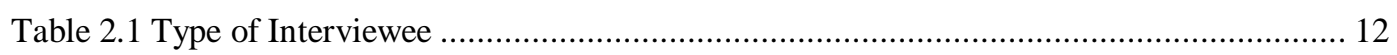

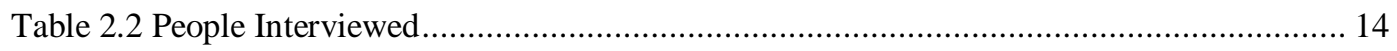

Table 4.1 Brazil's Income Distribution Amongst the Economically Active Population................. 39

Table 4.2 PT Results in Brazilian Municipal Elections ............................................................. 43

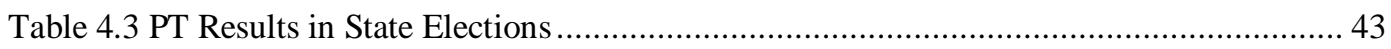

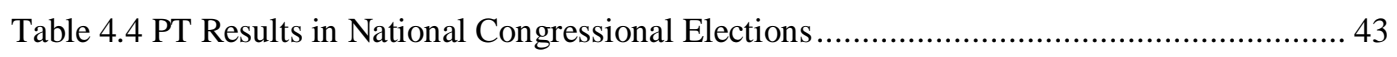

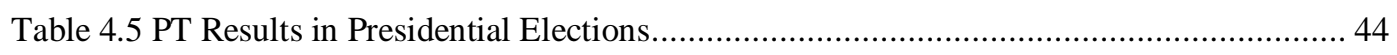

Table 6.1 Human Development Indices for Brazilian Cities with Populations Greater

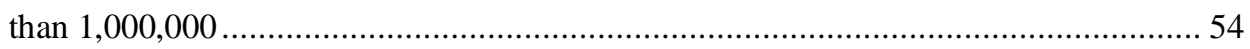

Table 6.2 Per-capita Income of Brazilian Cities with Populations of more than

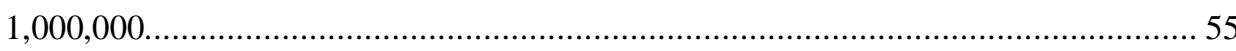

Table 6.3 Gini Coefficient of Brazilian Cities with Populations of more than

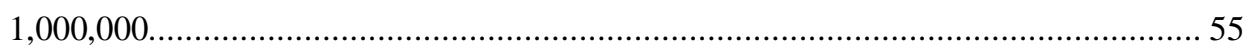

Table 6.4 Economic Status of Participants in Porto Alegre's Participatory Budget ....................... 70

Table 7.1 Breakdown of Participatory Budget Participants by Family Income.......................... 102

Table 8.1 Comparative Social and Economic Statistics for Porto Alegre and Belo Horizonte. 


\section{Chapter 1 - Introduction, Aims and Objectives}

\subsection{Introduction}

At a cursory glance, the term 'Participatory Democracy' appears to be a pleonasm. Participation, one would think, ought to be inherent to the concept of democracy. Indeed, according to conventional wisdom, it is popular participation that provides democracy with the checks and balances that distinguish it from totalitarian political systems. Yet a more detailed look at the functioning of modern democracies reveals that often the scope for genuine participation is much more limited than the prevailing rhetoric might suggest.

In many countries in the western world the proportion of the population that participates in the electoral process has been steadily declining. At the same time, studies show that the public often trusts its elected representatives less than it does other professionals or public figures (Hall 2004; Nylen 1999; Wainwright 2003). In the west at least, apathy and cynicism seem to be as much a part of the democratic process as does participation. Meanwhile, in the developing world, democratic governments are increasingly replacing totalitarian regimes, yet democracy - while often bringing real benefits in terms of human rights - has not, in many cases, brought with it significant economic benefits for the poor. This is an important shortcoming especially when one considers the fact that lower socioeconomic groups make up the majority of most developing world countries' populations.

Furthermore, with the rise to pre-eminence of neo-liberalism and the increasing power of international finance, voters in both the western and the developing worlds are finding that, when it comes to economic policy, the choices offered to them by major political parties are becoming increasingly limited. Central banking laws have removed from the public sphere any choices involving the trade-off between inflation and unemployment; governments are forced to take into account the potential actions of international investors when formulating policy; and developing countries often have policy choices imposed upon them by unaccountable multilateral organisations (Friedman 2000; Monbiot 2004; Stiglitz 2002; Wade 2003).

It seems ironic then, that as the number of people able to participate in democratic elections has been increasing, the choices which they have available to them, along with the enthusiasm with which they participate, has apparently decreased. One consequence of this decline in voter enthusiasm has been an increased interest in the use of alternative 
participatory processes in politics. In particular, encouraging participation through community consultation has become popular as governments seek ways to overcome voter apathy or obtain legitimacy (Wainwright 2003).

Outside the realm of politics, the concept of participation has also become increasingly discussed in the field of development. Writers such as Robert Chambers (1998) have argued that development projects should be facilitated by the active participation - in both the design and implementation phases - of those at its 'receiving end'. Proponents of increased participation in development claim that it is only fair that the recipients of development should have a larger say in what is actually undertaken; after all they are the ones who will have to live with the changes that occur. In addition to this, it is argued that increased participation in development will lead to more effective change as people living in an area will often have a better knowledge of what is required (and of any potential pitfalls) than will outside 'experts' who have only been exposed to the region's complex realities for a short period of time (Brohman 1996; Chambers 1998). Propelled by the strength of such arguments, participation has become an integral aspect of many development projects.

Yet, too often, in both development projects and in politics, the rhetoric of participation is considerably stronger than the reality of what is being offered. While organisations such as the World Bank are keen to project a participatory image, their projects - reflecting their own internal structure - still tend to be top-down (Abers 2000). Furthermore, there is a peculiar irony to talk about participation when it is accompanied by the imposition of neo-liberal economic policies. And, in the political sphere, public consultation is often limited to consultation and nothing more; if the public ever proposes anything that differs from the opinions of the state's appointed experts or the requests of more powerful interests, its submissions are deemed impractical and ignored (Abers 2000; Fung \& Olin Wright 2003; Wainwright 2003).

Not all attempts at encouraging increased participation are purely cosmetic though, and the study that follows examines a participatory political process - with development implications - that appears to offer opportunities for real decision making to its participants as well as tangible improvements to their quality of life. 


\subsection{Participation and Porto Alegre}

In 1988 the Partido dos Trabalhadores (in English - Workers' Party; hereafter referred to as PT) won the mayoralty in the Brazilian city of Porto Alegre and, in its first term in office, introduced a system of participatory budgeting which devolved to the city's citizens the power to decide how the investments component of the municipal budget was spent. This public decision-making power was facilitated by a political process that mixed direct assembly-style democracy with more conventional representative democracy (the way the system works is described in detail in Sub-chapter 6.5).

Initially the participatory budget was unsuccessful in Porto Alegre; the city government had no money available to spend on citizen's proposals and, as a consequence, participation fell between 1989 and 1990 (Abers 2000; Goldfrank 2003). However, in subsequent years as municipal finances improved, the participatory budget started to function effectively and participation began to rise. What is more, evidence began emerging which indicated that the participatory budget was a considerable success not only in terms of participation but also as an efficient system of municipal government which facilitated the improved distribution of municipal services to lower socio-economic groups, and effectively eliminated clientelistic ${ }^{1}$ and corrupt political practices in Porto Alegre (Abers 2000; De Sousa Santos 1998; Novak 2002; Souza 2001). In 1996 the participatory budget was selected as an example of best practice at the United Nations' Habitat Conference (Goldfrank 2003) and even the World Bank has published favourable reports on it (Shah \& Wagle 2003).

\subsection{The Need for A Broader Research Focus}

It is not surprising then that an increasing number of researchers are starting to investigate the participatory budgeting process in Porto Alegre. Nor is it surprising that the PT - who have been re-elected three times in Porto Alegre, thanks at least in part to the participatory budget - have been eagerly introducing the process in other cities where they occupy the mayor's office. This keenness to export the participatory budget, along with the PT's increasing municipal electoral success, has meant that participatory budgeting process is

\footnotetext{
${ }^{1}$ The Oxford English Dictionary Online (2004, p. 1) defines clientelism as “A social or administrative system which depends upon relationships of patronage, favouritism, and self-interested exchange; a political culture which emphasizes or exploits such relationships; the practice of such relations." In the context of Latin American Politics clientelism more specifically refers to an exchange in which a politician provides public goods or some other service to a section of the public in exchange for votes.
} 
now in use, in some form or other, in over 140 Brazilian cities (Bhatnagar et. al. 2003, p. $1)$.

At this stage however, there is a disparity between the number of Brazilian cities that have the participatory budget and the number of cities where the participatory budgeting process has been researched; indeed the majority of the research this far has focused on one city alone - Porto Alegre (Nylen 2003). While the case of Porto Alegre has certainly deserved much attention, the spread of the participatory budget to other Brazilian cities means that is now important that the research focus be broadened to include other examples of the process. In particular, this is necessary because Porto Alegre is, in many ways, an atypical Brazilian city; it is relatively wealthy, has Brazil's highest Human Development Index (HDI) and has a history of political activism (UNDP Brazil 2000; Wainwright 2003). When these facts are taken into account, it does not seem impossible that the participatory budget might be something that can only function in Porto Alegre or, at least, only function in a few more affluent Brazilian cities. So a broadening of the research focus is necessary to ascertain just how transferable the participatory budget really is. In addition to this, studying the participatory budget in other cities, where it will have encountered different social, political and economic conditions, will enable a more detailed picture to be built up of just how these conditions affect the outcomes of the process. This, in turn, may help the PT and other agents interested in implementing the participatory budget modify the process so that it can operate in the greatest variety of locations.

It is with the hope of assisting in this 'broadening of the research focus' that I have based my dissertation on the participatory budget in Porto Alegre and also Belo Horizonte; comparing the well known Porto Alegre with Belo Horizonte, a less well researched and different city.

\subsection{Research Aims and Objectives}

\section{Research Aim:}

To examine and compare the participatory budgeting experiences of Porto Alegre and Belo Horizonte with the intention of outlining key local variables that are important in influencing the outcomes of the participatory budgeting process. 


\section{Research Objectives:}

1. To place the participatory budget within the broader context of Brazilian political economy and political culture.

2. To assess the reported successes of Porto Alegre's participatory budget model.

3. To identify any problems encountered by, and/or limitations associated with, the participatory budgeting model in Porto Alegre.

4. To assess the participatory budgeting process in Belo Horizonte to see if/where it has been successful.

5. To identify any problems encountered by, and/or limitations associated with, the participatory budgeting model in Belo Horizonte.

6. To compare the outcomes of the participatory budgeting process in the two cities.

7. To use the above analysis (along with any other relevant material on Participatory Budgeting experiences in Brazil) to identify key variables which may influence the outcomes of the participatory budgeting process when it is applied in different locations.

\subsection{The Structure of this Dissertation}

The remainder of this dissertation is structured as follows:

\section{Chapter 2}

In Chapter 2 I provide the reader with an outline of my position amongst the various constellations of epistemology. I also link my epistemological approach to the methodology I use; showing how the methodology used has been shaped by epistemological choices, along with other factors. Having explained my choice of methodology I then move on to explaining the choice of setting: why I chose to undertake research in Porto Alegre and Belo Horizonte. After that, I give a detailed description of the research methods that I used, following this with a discussion of the ethical considerations relevant to my research. In the final part of the chapter I outline some of the problems that I encountered while undertaking the research.

\section{Chapter 3}

In Chapter 3 I provide background information on democratic theory along with theories of participation in democracy and participation in development. This is undertaken with the intent of enabling the reader to place the participatory budgets of Porto Alegre and 
Belo Horizonte within a theoretical context. I also explain concepts such as Direct Democracy, Representative Democracy and Participatory Democracy.

\section{Chapter 4}

Chapter 4 is the first of two chapters in which I describe the broader practical context that the participatory budgets of Porto Alegre and Belo Horizonte take place amongst. In Chapter 4 I examine the political history of Brazil from its founding as a Portuguese colony through periods of dictatorship and democracy until the present day. In particular, I pay close attention to the space available to popular participation in Brazilian politics as well as the degree to which elite groups have dominated politics in the country.

\section{Chapter 5}

In Chapter 5 I continue the explanation of the contextual background to participatory budgeting. In particular, I examine the history and functioning of the PT, the Brazilian political party that introduced the participatory budgets to both Porto Alegre and Belo Horizonte, and which has offered the first significant challenge to the elite domination of Brazilian politics. As well as examining the PT I examine their history of municipal governance in Brazil. In doing this I pay close attention to the multitude of problems that have befallen the PT in the cities that they have governed. This is important because, in both Porto Alegre and Belo Horizonte, the participatory budget is integrally linked to the PT meaning that any problem that befalls the PT will be likely to affect the participatory budget as well.

\section{Chapter 6}

In Chapter 6 I narrow the research focus, concentrating on the participatory budgeting experience in Porto Alegre. I start by giving some important background information on Porto Alegre before explaining in detail how the participatory budgeting process works in the city. Following this explanation, I discuss the successes of the participatory budget in Porto Alegre along with the problems it has encountered there. I also outline the apparent limitations of the participatory budget in Porto Alegre and, finally, I highlight areas where the outcomes of the participatory budget appear to be unclear.

\section{Chapter 7}

In Chapter 7 I repeat the undertakings of Chapter 6, this time focusing on the participatory budget in Belo Horizonte. I provide background information on Belo Horizonte and 
examine how the participatory budget works in the city. I then move on to outline the successes of, problems encountered by, and limitations of the participatory budget in Belo Horizonte. Finally I examine the areas where the outcomes of the participatory budget in Belo Horizonte have, so far, been unclear.

\section{Chapter 8}

I start Chapter 8 with a comparison of participatory budgeting in Porto Alegre and Belo Horizonte. In this I compare some socio-economic characteristics of the cities themselves as well as comparing how the results of the participatory budget have varied between Porto Alegre and Belo Horizonte. Following the comparison, I then move on to discuss the key variables, identified through my research, that affect the outcomes of the participatory budget.

\section{Chapter 9}

In the final Chapter of this dissertation I make my conclusions. I summarise the findings of my research and discuss their significance. I also address the limitations of my study and identify areas where further research is needed. 


\section{Chapter 2 - Epistemology, Methodology and Methods}

\subsection{Introduction}

The truth, it would seem, is no longer out there. Or, at least in the case of social science research, there are now so many different species of truth in existence that it is expected that any serious researcher will declare up front exactly which type of truth they themselves are hunting; only once this declaration has been made can they then get on with explaining how they intend to capture it. It is hoped that, by explaining their epistemological approach (the type of truth they plan to hunt), the researcher will be forced to make clear the assumptions that inevitably underlie any research; this, in turn, will enable the reader to interpret the results they are reading in a more holistic manner; one which places the 'facts' amongst the world views. In this spirit, the following chapter explains briefly the epistemology that I have used for my research. I then detail my methodology and research methods. Finally, I chronicle some of the limitations of this research method along with some of the practical problems encountered during the research process.

\subsection{Epistemology}

Like all other areas of philosophy, epistemologies are contentious and it is beyond the scope of this dissertation to delve into the debates about epistemology or provide a theoretical justification for my epistemology here. Instead, I simply describe what the epistemology I have used is, its historical pedigree, and how it has influenced the methodologies chosen in my research.

The epistemology I have used in this research can broadly be described as Critical Realism: a blend of Realism and Critical Theory. My approach is Realist in the sense that it accepts that there is 'real world' out there, one that exists independently of our senses and perceptions. It is also Realist in that it asks 'how and why questions' about changes that take place in the interactions between people and society (Johnston et. al. 2000; Kitchin \& Tate 2000). The Critical Theory that accompanies this Realism is associated with the reformulations of orthodox and Western Marxism undertaken by the 'Frankfurt School' of social scientists ${ }^{2}$ and, more recently, by Jürgen Habermas (Johnston et. al. 2000; Thompson 1981). Critical theorists agree with Marx that social sciences should

\footnotetext{
${ }^{2}$ The Frankfurt School refers to a group of scholars working at the Institute of Social Research of the University of Frankfurt during the 1920s and 1930s.
} 
study the world with the purpose of promoting emancipatory change (Groves \& Robinson 1998; Johnston et. al. 2000). Critical Theorists also agree with Marx that changing means of production and their effects on individuals and society are important, however, they argue that focusing on means of production alone - as classical Marxists did - is insufficient for a social theory. Critical theorists argue that the social sphere should not merely be viewed as something peripheral to the political economy but also as an important source of influence that needs to be studied. To Critical Theorists the interactions between an individual and society (the interactions flow both ways) are much more broad in scope than just the exchange of labour for a wage (Johnston et. al. 2000; Thompson 1981).

Therefore my topic of research reflects a Realist and Critical Theorist approach: in both Porto Alegre and Belo Horizonte I have studied how and why a socio-political change has affected individuals, and how the affected individuals have, in turn, acted to change the society they live within.

My research also reflects Realist and Critical Theorist approaches to methodology. It is Realist in that I am asking how and why questions about social change, and Critical Theorist in that it reflects Habermas' belief that empirical analysis alone is insufficient: 'facts' do not just speak for themselves but rather require interpretation (Thompson 1981; Johnston et. al. 2000).

One final epistemological point that is important relates to positioning; while my approach is, to a degree Realist and accepts a real world that can be studied, I am also aware that all research contains some subjective components. Humans see the real world through the filter of their own beliefs and experiences. I am aware of this and have tried to minimise imposing my own beliefs on top of the 'facts' that I have collected.

\subsection{Methodology}

Methodologically, I have used a mixture of quantitative and qualitative research in my dissertation. This methodological choice is a reflection of the epistemology that I have chosen to work under. It also reflects the belief - expressed by Murray and Overton (2003), Brockington and Sullivan (2003) and others - that quantitative and qualitative research techniques are not mutually exclusive but can be used to complement each other. I have used quantitative research to identify large-scale changes within the cities I studied (such as the percentage of population with basic sanitary facilities or the number of 
people participating in budget meetings). And, at the same time, I have used qualitative research to complement the quantitative approach by capturing information that cannot be represented numerically (e.g. what are the differences in ideology between the PT in Porto Alegre and the PT in Belo Horizonte) as well as trying to explain trends identified by the quantitative data (if participation has gone up then why has it gone up?). While qualitative research has at times been criticised as arbitrary or a poor substitute for quantitative research, this is not the case; equal analytical rigour can be applied to qualitative research as to quantitative (Brockington \& Sullivan 2003). And, in the complex world which we study, there are simply some things that cannot be measured numerically (Johnston et. al. 2000).

\subsection{Choice of Setting}

As I have described in my introductory chapter, most of the existing research on participatory budgeting has focused on the process in Porto Alegre despite the fact that there are now over 100 Brazilian cities using the some type of participatory budgeting system. While it made sense for Porto Alegre to be the initial focus of research into participatory budgeting - it was the first large Brazilian city to implement the process with any real degree of success and the process has been running there the longest - it also seems sensible that researchers should now start looking into participatory budgeting in the other cities where it is being used. The rationale for this broadening of focus is twofold. For a start it is necessary to ascertain whether participatory budgeting can work in other cities or whether its successes are merely something unique to Porto Alegre. Secondly, as the participatory budget is applied to new settings it will invariably encounter new challenges, which will determine if the process will be successful or not in these new locations. Studying how the participatory budget performs in different conditions will enable a more complete picture of participatory budgeting to be created, one that outlines how different local conditions can cause the participatory budget to succeed or fail.

In the spirit of this 'broadening of the research focus' I chose to study the participatory budget in both Porto Alegre and Belo Horizonte. Porto Alegre was chosen for two reasons, the first was practical: given the limited time I had available and my limited financial resources, studying Porto Alegre meant that I could take advantage of the large amount of existing research available on the city. The second reason was that I planned to use Porto Alegre as a control - the participatory budget there was a relatively well-known entity, one which I could compare to the less well researched Belo Horizonte. 
Belo Horizonte was chosen as the second research site for a variety of reasons. Firstly the participatory budgeting process has been in operation there for a significant length of time (11 years). (The only cities, other than Porto Alegre, that have had participatory budgets for longer than Belo Horizonte are much smaller cities such as Ipitinga.) The assumption that the participatory budget would need to have operated for several years at least before its efficacy could be assessed seemed a sensible one. Belo Horizonte was also chosen because it differed from Porto Alegre in several important ways: it was significantly larger than Porto Alegre having a population of 2,238,526 to Porto Alegre's 1,320,739 (UNDP Brazil 2000); it had a lower Human Development Index Rating than Porto Alegre (0.839 compared to Porto Alegre's HDI of 0.865) (UNDP Brazil 2000) and it had a different political culture to Porto Alegre (Abers 2000; Hagopian 1996). I hoped that these differences would help me ascertain some of the factors, which can vary from location to location, that might be significant in influencing the outcomes of the participatory budget.

Finally I also chose Belo Horizonte for some of the same practical reasons that I chose Porto Alegre. While Belo Horizonte has not been as comprehensively researched as Porto Alegre, there has been some research done on the participatory budget there. This meant that, with the limited time and money available to me, I could still take advantage of some existing material in my investigations. It also meant that I was able to interview Brazilian academics who had undertaken research on the participatory budget in Belo Horizonte.

\subsection{Methods Used}

\subsubsection{A Mixture of Primary and Secondary Research}

In researching this dissertation I used a mixture of primary and secondary research. The secondary research had two components. The first was a literature review - undertaken before my field research - in which I reviewed contextual literature (books on Brazilian Political History and Democratic Theory) as well as any material on the participatory budget in Porto Alegre that I could obtain (either via library databases or off the Internet). From the original literature review I was able to write the dissertation's background chapters as well as formulate my research objectives and aims. The literature review also enabled me to compose some of the questions that I would ask in my interviews as well as identify some potential interviewees. The second component of my secondary research involved the use of more recent academic articles that I was able to obtain in Brazil as well as information (in book and pamphlet form) that was provided to me by the municipal government employees and academics that I interviewed. All of the empirical 
data was obtained from secondary sources since the time and monetary limitations associated with undertaking a 60-point dissertation made it impossible to obtain this sort of data by any other means. I also drew on some of the qualitative research of other authors in an effort to obtain a broader and more textured understanding of the participatory budgeting process.

\subsubsection{A Comparative Approach to Primary Research}

Clearly, the nature of my research aim and objectives meant that I required some form of comparative approach to interpret the information I obtained in the two cities. To facilitate this approach I attempted to interview a similar spectrum of people in both cities.

Table 2.1 shows my planned interview structure.

Table 2.1 - Type of Interviewee

\begin{tabular}{|l|}
\hline Interviewee Type \\
\hline PT Councillor \\
\hline Opposition Councillor (right wing critic of process) \\
\hline Left Wing critic of process \\
\hline Bureaucrat Involved in administering the participatory budget process \\
\hline Academic who had researched the participatory budget \\
\hline $\begin{array}{l}\text { Non-Governmental Organisation (NGO) observer of the participatory } \\
\text { budget }\end{array}$ \\
\hline Commentator on the political climate/history of the cities \\
\hline
\end{tabular}

\subsubsection{Semi-Structured Interviews}

The subjects were interviewed using semi-structured interviews, which were recorded using a Dictaphone (I also took brief notes while the interview was taking place). The semi-structured interview process allowed me to do two things. Firstly it enabled me to ask a similar core group of questions to all the interviewees. I did this with the intent of being able to compare the answers from different participants to see where agreement existed on issues as well as to contrast the answers given in Porto Alegre with those given in Belo Horizonte in the hope of identifying differences between the two cities. While I attempted to ask the same core group of questions to all participants, the semi-structured interview process also allowed flexibility to further explore (via additional questions) any particularly pertinent or interesting responses participants gave. It also gave the respondents a chance to articulate any additional issues that they thought were important something that is not possible when a rigid 'questionnaire' approach to interviewing is 
followed (Brockington \& Sullivan 2003). In addition to asking the same group of core questions to participants and soliciting any other opinions that they had, I also asked some of the participants individualised questions on topics particular to their experiences of the participatory budgeting process. For example, I asked some of the academics questions about their own research to clarify points they had raised in published research.

\subsubsection{Critical Analysis}

Obviously consensus (or even a majority of opinions) did not occur in the responses to all of the questions I asked. Where there was disagreement, I attempted to use analytical rigour as well as engagement with secondary research to try to clarify the issues raised. In some cases clear answers simply were not available. When this occurred, I simply highlighted both sides of the contested issue and identified the need for subsequent research.

\subsubsection{Finding My Participants}

Starting with the broad conceptualisation of potential participants outlined in Table 2.1, I then used Internet searching, interviewee referrals to other interviewees, and a degree of serendipity to actually contact participants and arrange interviews.

From the background literature review I was able to identify some of the people I wished to interview (primarily academics who had published some of the research that I had encountered). I was then able to search the Internet for their email addresses using their names and the names of the organisations that they worked for. With this information I was able to contact them via email (or occasionally telephone) and arrange interview times.

The initial contacts I made were also used as 'gatekeepers': people who were able to recommend other people for me to interview (Murray \& Overton 2003). In this sense many of the interviewees were obtained using what is often referred to as the 'snowballing' approach - once the ball (my research) got rolling additional interviewees were picked up 'along the way' (Kitchin \& Tate 2000; Murray \& Overton 2003).

It may well be the case in all research, and it certainly seemed to be the case in Brazil, but I discovered that a significant proportion of the people I interviewed were much more receptive to being interviewed when told that $\mathrm{I}$ had been referred to them by someone else that they knew. For this reason my initial 'gatekeepers' were very important in enabling 
me to contact additional interviewees. This is also where a degree of 'luck' came into the process in so much as that I was able, through friends of friends, to make several important contacts in both Porto Alegre and Belo Horizonte. Contacts which I would not have been able to make otherwise. (For example, I was only able to interview a very prominent Porto Alegrean conservative politician, who had been a strong critic of the participatory budget, because he was married to the cousin of a friend). Table 2.2 shows the 22 people that I was able to interview and how they (broadly) fit into the original conceptual framework that I outlined in Table 2.1

Table 2.2 - People Interviewed

\begin{tabular}{|c|c|c|}
\hline Type of Interviewee & Porto Alegre & Belo Horizonte \\
\hline PT Councillor & Sofia Cavedon & $\begin{array}{l}\text { Rose Mary Lisa Salvo } \\
\text { (worked for PT councillor) }\end{array}$ \\
\hline $\begin{array}{l}\text { Right Wing Opposition } \\
\text { Councillor }\end{array}$ & Requested Anonymity & Requested Anonymity \\
\hline Left Wing Political Critique & & Marcos Santana \\
\hline $\begin{array}{l}\text { Person Involved in } \\
\text { Administering the } \\
\text { Participatory Budget }\end{array}$ & $\begin{array}{l}\text { Mariela Moraes \& } \\
\text { Márcia da Silva } \\
\text { Quadrado }\end{array}$ & $\begin{array}{l}\text { Paula Romanelli Simões } \\
\text { \& Gilma Carmélia Alves } \\
\text { dos Santos }\end{array}$ \\
\hline $\begin{array}{l}\text { Person Involved in } \\
\text { Administering the } \\
\text { Participatory Budget }\end{array}$ & Luis Alberto Giradi & $\begin{array}{l}\text { Rodrigo Barroso } \\
\text { Fernandes \& Maria } \\
\text { Auxiliadora Gomes }\end{array}$ \\
\hline $\begin{array}{l}\text { Person Involved in } \\
\text { Administering the } \\
\text { Participatory Budget }\end{array}$ & Alexandre Stolte & \\
\hline Academic & Marcelo Kunrath Silva & $\begin{array}{l}\text { Clarice Barreto Linhaus \& } \\
\text { Roberto Rocha Coelho } \\
\text { Pires }\end{array}$ \\
\hline NGO Observer & Sergio Baierle & Maria da Paixão Dias \\
\hline $\begin{array}{l}\text { Commentary on Political } \\
\text { Climate }\end{array}$ & & Neusa Cardoso de Melo \\
\hline \multicolumn{3}{|c|}{ People Interviewed Elsewhere in Brazil } \\
\hline $\begin{array}{l}\text { Academic Interviewed in } \\
\text { Brasilia }\end{array}$ & Rebecca Naera Abers & \\
\hline From IBASE (Rio) & João Antonio Sucupira & \\
\hline From IBASE (Rio) & $\begin{array}{l}\text { João Roberto Lopes } \\
\text { Pinto }\end{array}$ & \\
\hline
\end{tabular}


Clearly there are several differences between the interview structure that I hoped for and the interview structure that I achieved. Firstly, time constraints meant that I was not able to interview anyone who could provide a left wing critique of the participatory budgeting process in Porto Alegre. (I did, however, obtain a book while I was there which offered some of this critique.) Secondly, I conducted three interviews with people involved in the operation of the participatory budget in Porto Alegre and two interviews with people involved in the operation of the participatory budget in Belo Horizonte. This reflected the fact that both municipal governments had two separate departments involved in administering the process. The 'extra interview' with a government worker in Porto Alegre took place because, after I had observed the participatory budget in action, I had some additional questions - so I arranged the interview to try to get these questions answered. Thirdly, I interviewed some additional people not included in my original framework. Neusa Cardoso de Melo, a political activist, was interviewed to obtain more information about the political history of Belo Horizonte. Rebecca Naera Abers was interviewed in Brasilia, where she now works at the Federal University, because she has published some of the most comprehensive research on participation in Porto Alegre and Brazil in general. João Antonio Sucupira and João Roberto Lopes Pinto both worked for the Brazilian Institute for Social-Economic Analysis (IBASE), a long standing Brazilian non-governmental research agency that has undertaken considerable research into numerous different political, social and economic aspects of Brazil (Wainwright 2003). Included in IBASE's research has been a significant amount of work in participatory budgeting processes in Brazil. I initially planned to interview only the institute's director, João Antonio Sucupira. However, he also arranged for me to interview João Roberto Lopes Pinto, a researcher who had studied Porto Alegre and who had also been involved with the PT government of Rio de Janeiro State, and so had some hands-on experience of operating a participatory budgeting process (the PT has attempted to operate statewide participatory budgets in the states that it has had power in).

\subsubsection{Observing the Participatory Budget in Action}

In addition to the semi-structured interviews, I attended four meetings of the participatory budget (two in Porto Alegre and two in Belo Horizonte). While the number of meetings was too small to draw any meaningful conclusions about the participatory budgeting process (two meetings out of the multitude of participatory budget meetings that take place would not constitute a significant sample size), attendance at the meetings did help me generate reasonably pertinent questions about the process. Questions that I was then able to ask interviewees. 


\subsection{Ethical Considerations}

In accordance with Victoria University of Wellington's code on ethics for research with human subjects, I provided everyone I interviewed with an information sheet that explained, in detail, the purpose of my research as well as the expected end product of the research (what I intended to publish and who might be able to access this information). Interviewees were also required to sign an 'informed consent form' which explained clearly their rights within the research process. These rights included the right to withdraw themselves and any comments they had made from the research process at any stage up to the publication of the dissertation. Both the information sheet and informed consent form were approved by Victoria University's ethics committee, and both were translated into Portuguese (see Appendix 1).

All but two of the interviews were recorded with a Dictaphone. When interviews were recorded, the interviewees were asked for their consent to this and also advised that they could ask for the Dictaphone to be turned off at any time during the interview. Interviewees were provided with a clearly explained choice between making comments that could be attributed to them directly and making comments that would only be used in a manner that protected their anonymity. Interviewees were also able to request that a summary of my research results be sent to them upon completion of the research. The cassettes upon which the interviews were recorded, along with any transcripts of the interviews or notes taken during the interviews, will be destroyed within a year of my research being completed. In the meantime they are being stored in a secure location. The person who assisted me in the transcription and translation of the interview tapes signed a confidentiality agreement, which prevents her from disclosing any of the information from the interviews to third parties (see Appendix 1).

By undertaking the above I have acted in accordance with the University's ethics policies. It is worth noting, however, as Scheyvens et. al. (2003) do, that ethical considerations in development field work should run deeper than merely obtaining ethics consent from an academic institution and that researchers should always consider the potential effects of their research on research participants. In some ways this task was made easier for me because I was not interviewing particularly marginalized or vulnerable people. Instead I was interviewing NGO staff, academics, politicians and bureaucrats, all of whom were reasonably well educated and were from middle class, upper middle class or elite sectors 
of Brazilian society. Likewise most, if not all, of the participants had previous experience with being interviewed (or interviewing people) either with the media or in an academic setting.

\subsection{Problems Encountered}

Conducting research in a country other than your own can be difficult. Leslie \& Storey (2003, p. 119) advise that the novice researcher, in particular, "may be paralysed with...[a] kind of fear, self-doubt and uncertainty". They then go on to say (2003, p. 119) that "[f]eelings of going mad, panic in the field and constant high anxiety...are all normal predicaments faced by most researchers". Fortunately, during my time in Brazil, which was my first research experience in the developing world, I did not experience the extremes of psychological discomfort that Leslie and Storey describe. I did, however, struggle at times.

With respect to the alienation and loneliness that can plague researchers located in another country a long way from family and friends (Leslie \& Storey 2003) I was relatively lucky. I already had several personal contacts in both Porto Alegre and Belo Horizonte; these people, through their friendliness and openness, went a long way to ensuring that I was never overly lonely in either city. Being able to speak some Portuguese helped as well, enabling me to have contact and conversations throughout my day-to-day activities. I was also fortunate when it came to avoiding culture shock because I had already travelled a great deal through Latin America, often on my own. So, to a degree, I was spared the sensation of 'overwhelming newness' which can confront researchers in other countries.

With regards to my actual research process, once again, some previous experience with travelling in Latin America assisted to a degree, particularly when it came to expecting transport delays and other hurdles as well as being able to cope with the odd instance when interviewees cancelled interviews without bothering to advise me of the fact. I would argue that independent travelling anywhere (not just the developing world) is typically a good teacher when it comes to learning to expect the unexpected and cultivating patience in dealing with people.

Some things I was not prepared for though. In particular, I had never expected to discover that Dictaphones were such treacherous, untrustworthy devices. Despite the fact that I often took two Dictaphones into interviews I still lost significant proportions of some 
interviews to road noise, tapes which ran out, batteries that went flat and, in one case, a tape that snapped in two.

Another problem that I suffered from was my level of proficiency in the Portuguese language. While I did speak Portuguese well enough to manage my day-to-day affairs in Brazil, my ability with the language was not quite adequate for the interview process. I was able to ask pre-prepared questions easily enough, however, I sometimes struggled to articulate additional questions. This meant that interviews were not as flexible as I had hoped them to be. In addition to this I did not always understand the responses to the questions I asked (this was particularly a problem when the respondents became excited and started speaking fast). By recording the interviews I was able to overcome this issue the aforementioned problems with Dictaphones notwithstanding. Upon my return to New Zealand my Portuguese teacher and I then went through the tapes translating what had been said on them.

Obviously there are some potential pitfalls to having an additional person involved in the interview process, either as an interpreter who translates the interviews while they are taking place or as a translator who translates the interviews at a later date. If a researcher chooses to have the interviews translated at a later date, Leslie and Storey (2003) argue that a real risk exists that the person translating the interviews may either misunderstand the meaning conveyed by the interviewee or impose their own interpretation of events upon what the interviewee said. I accept that by using this 'translation at a later date method' I ran the risk of distortion occurring, however, I feel there are several reasons why this risk was minimal. For a start, my translator was a well-educated Brazilian woman who has been living in New Zealand for a long time. Her educational background meant that she had little trouble understanding the political concepts that were discussed in the interview and, while she was interested in the participatory budgeting process, she did not have any strong pre-existing views about it. Furthermore, I had my own notes from the interviews and we listened to the tapes together while translating them, which provided a double check on meaning. If she said anything that conflicted greatly with my own notes or my own understanding of what the speaker was saying on the tape, I was in a position to ask for clarification (in practice, I never needed to do so).

A final methodological issue is that, because I am not a Brazilian and because my time in Brazil was relatively short, I may have failed to spot or correctly understand cultural subtleties and political realities in the cities that I studied. I hope that by interviewing 
Brazilian academics, politicians and bureaucrats, and obtaining their opinions of the processes at work, I have overcome this shortfall. However, it remains a potential limitation. 


\section{Chapter 3 - Democratic Theory and Participation}

\subsection{Introduction}

While participatory budgeting is a practical experiment, it also has theoretical underpinnings. The following chapter provides an outline of democratic theory. It also looks into the arguments about the role of participation in democratic governance. Finally, because the participatory budget has development ramifications and because many large development organisations such as the World Bank are following the participatory budgeting experiments with keen interest, this chapter outlines the case for increased participation in the development process.

\subsection{Basic Democratic Theory}

Despite the fact that democracy is often thought of as a twentieth century phenomenon, neither the word 'democracy' nor the concept that it represents are in anyway new. 'Democracy' comes from the Greek word demokratia, which means, literally, 'rule by the people'. Demokratia itself was first used to describe the system of government that existed in some of the city-states of ancient Greece at about 500 BC. The most famous of these democratic city-states was Athens. Demokratia in ancient Athens described the process with which the city was governed through large municipal assemblies where all male adult citizens had the right to participation in the creation of the city's laws. With its public meetings and randomised selection of city officials by ballot, Athenian democracy was significantly different from what we call democracy today. However, there is an underlying principle that connects the ancient Athenian system and modern democratic states: the concept of popular political participation. Theoretically, at least, both in ancient Athens and in modern democracies, a significant proportion of the population has an institutionalised role at some point in the process of choosing the laws they live under (Dahl 1998; Encyclopædia Britannica 2004d).

Athenian democracy was, technically, a form of direct democracy (i.e. citizens made direct decisions about the rules they live under). When the term democracy is used today, however, it is typically used to describe political systems where, rather than governing directly, people's political participation is focused on election of (and, more controversially, the influence of) those who will rule on their behalf. The correct term for this type of democratic system is representative democracy. With regards to representative democracy, Mayo (1960, p. 60) argues that "a political system is democratic to the extent that the decision-makers are under effective popular control". 
Expanding upon Mayo, Dahl (1998) highlights five components that he considers integral to modern representative democracy. These standards are:

1. Equal opportunity - all members of a democratic society will have equal and effective opportunities for making their views known to other members;

2. Voting equality - no one member's vote will be given more weight than any other's in the election of representatives;

3. Understanding - opportunity is provided to all participants to obtain an enlightened understanding of the decision being made;

4. Control of agenda - all participants should have a chance to put forward that which is going to be discussed;

5. Inclusion - participation should be available to all adults.

From Plato (who lived in Athens at approximately the time of its democratic rule) onwards there have been numerous critics of democracy and its basic precept - popular participation in the legislative process.

Plato argued that democracy would degenerate into demagoguery and mob rule, with the masses unlikely to act on any impulse other than short term self interest. Furthermore, he argued the average citizen was too ignorant to be able to make informed choices around the intricacies of statesmanship. Much better in the view of Plato, that the people be governed by an elite, enlightened ruling class (Plato's term for the ruling elite was 'guardians') (Mayo 1960).

More recently, those advocating totalitarian regimes have continued Plato's criticisms of the principles of democratic rule. Fascists and their supporters have argued that democratic governments are inefficient. While others such as the former prime minister of Singapore, Lee Kuan Yew, have argued that democracy is only applicable in certain cultural and economic circumstances, and that at other times totalitarian regimes will be more effective (Jacques 2004; Pateman 1970; Sen 1999).

While democracy's totalitarian critics have a long historical pedigree, so do its defenders; arguments in defence of democracy run back at least as far as the ancient Greeks. Aristotle, while critical of democracy, claimed in democracy's favour that a majority of citizens were more likely to be right than any one individual (Mayo 1960). 
The arguments used by modern defenders of democracy against proponents of more totalitarian systems tend to fit into three broad categories: philosophical, instrumental and developmental.

The philosophical case for democracy is based around rights. All human beings should, the proponents argue, have the basic right to have some say in the development of laws and policies that affect them. Furthermore, there is no inherent ethical or moral reason why any part of society should be excluded from its decision making process in favour of the increased powers of any other sector of society. Moreover, they argue, there are limitations to the abilities of technocrats (or Platoesque guardians) to plan a country's future. Often decision-making involves trade-offs where there either is no correct answer or no certain way - short of travelling forward in time - to determine what choice to make. And in other instances, reason alone cannot determine what course of action to take - moral choices must be made. If such unsolvable dilemmas will affect the majority of a country's population, democrats argue, then ethically the majority of the population should have some role in the decision making process (Dahl 1989; Dahl 1998; Mayo 1960; Pateman 1970; Parry 1972).

From an instrumentalist perspective, democracy is seen as the best possible defence against tyranny and abuse of power by ruling elites. Instrumentalist supporters of democracy also argue that democratic systems will be more likely than totalitarian regimes to lead to better overall outcomes for a majority of a country's population because political leaders will operate under the incentive of following the majority's interest (rather than following their own self interest) in order to stay in power (Dahl 1989; Dahl 1998).

The developmentalist defence of democracy argues that inclusion in the decision making process facilitates the development of more complete citizens. Democratic participation provides some moral ownership to citizens of the laws they live under, and so should encourage more reflection and thought on their behalf about their participation within society. It should also leave them more inclined to follow laws voluntarily without the need of coercion, leading to a society that is, by in large, more free (Dahl 1998; Dahl 1989).

Defenders of democracy can point to some fairly solid empirical evidence to back up their claims that democracy provides for better outcomes than totalitarian regimes. Amartya Sen $(1981,1999)$ has shown that no significant famine has ever occurred in a democratic 
country with a relatively free press. Likewise, democratic countries tend to be more prosperous than non-democratic ones (Prezworski et. al. 2000) and much less likely to go to war with each other (between 1945 and 1989 no wars occurred between democratic countries $^{3}$ ) (Dahl 1989; Dahl 1998).

All of which - along with the fact that there are no significant movements in any democratic country arguing for a return to totalitarian government - suggests that some form of democratic rule is preferable to non-democratic leadership. Yet, even a cursory comparison of either the theoretical defences made for democracy, or Dahl's characteristics of a democratic system with any real world democracy, highlights the limitations of most of the currently used forms of representative democracy.

For a start - beyond the act of voting - equal opportunity of participation is not given to all citizens in modern democracy (Dahl 1989). Instead, higher level participation such as running for office is largely limited to those who can afford or fundraise the money necessary to undertake such a venture. In some democracies even voting rights are not extended to all adult citizens (some states in the United States, for example, exclude convicted felons from voting, even after they have been released from prison) (Palast 1999). In addition to this, the ability of citizens living in representative democracies to influence their elected representatives is rarely distributed equally amongst populations. Often the wealthy and the well-connected (along with the well-organised), have far more ability to influence the decisions made by elected representatives than to their fellow citizens (Wainwright 2003).

Nor do all members of society have equal and effective opportunities to make their views known to other members. The ownership of traditional mainstream media outlets is highly centralised with the majority of media organisations being owned by relatively few companies. Numerous studies (see for example Chomsky \& Herman 1988) have shown how media outlet proprietors have used publication ownership to - either subtly or not so subtly - influence public opinion and control the content of 'acceptable debate'.

Moreover, information sources in many modern democracies are not structured in a way that makes it particularly easy for a typical citizen to obtain an informed understanding of

\footnotetext{
${ }^{3}$ During this period of time democratic nations did, however, wage covert wars against other democratic nations. Perhaps the most egregious example of this was the United States' support of the Contra rebels in their fight against the democratically elected Sandinista government of Nicaragua. It is worth noting, however, that this war was waged largely without the knowledge of the American public suggesting, more than anything else, that the democratic process in the USA is highly flawed.
} 
decisions being made. Political parties tend to campaign using sound bites and rhetoric while mainstream media outlets (along with the aforementioned bias) tend to opt for sensationalism and 'human interest stories' rather than in-depth analysis. For those who do seek a deeper understanding of issues, information is available via websites, academic journals and in some magazines. However, obtaining such information usually requires some effort and existing knowledge on peoples' behalf: qualities not necessarily abundant in a society trained to be passive recipients of media (Chomsky \& Herman 1988; Wainwright 2003).

At a practical level - as I have already outlined in the Chapter 1 - representative democracy has encountered other problems. In recent years, in the developed world, participation in the democratic process has declined significantly with voting numbers falling below half the eligible voters in some countries. At the same time, voters' trust of and respect for politicians has also, in many cases, fallen to particularly low levels (Baiocchi 2003; Hall 2004; Wainwright 2003). In the developing world democratically elected governments have often proven to be no more able than their dictatorial predecessors to eliminate corruption or ameliorate poverty (Branford \& Kucinski 2003).

All of the problems I have listed above have caused some activists and academics to examine the limits of representative democracy and ask whether it cannot be improved on. One common area of questioning has been the area of participation; in particular, are there other, better ways which people might participate in the democratic process rather than just vote periodically (Dahl 1998; Pateman 1970; Wainwright 2003)?

\subsection{Participation and Democracy}

Early democratic theorists such as Jean Jacques Rousseau and John Stewart Mill were, by and large, in favour of maximising the degree to which the population in general participated in the democratic process (Dahl 1998; Pateman 1970). To these classical theorists popular participation was the best defence against tyranny as well as the best way of developing fully conscious public citizens. These are the same arguments that modern theorists made for representative democracy, yet Rousseau in particular, was very critical of representative democracy, arguing that it was a sham and not true participation. Speaking on the representative system that existed in England at the time he said:

The English people, thinks it is free. It greatly deceives itself. It is only free during the election of the members of parliament. 
As soon as they are elected, it is a slave, it is nothing. (cited in

Dahl 1989, p. 226).

In his treatise 'The Social Contract' Rousseau argues for, as an alternative to representative democracy, an Athenian style system where decisions are made through city or community assemblies rather than the election of representatives. To Rousseau, maximum participation equated to maximum freedom and was also the best way to achieve the maximum public good (Dahl 1989; Dahl 1998).

However, there are some very serious limitations to Rousseau's proposed assembly-style democracy that would make it unsuitable as a means of governing a modern society. Dahl $(1989,1998)$ points out that, due to the sheer amount of time required, meetings where everyone had the right to participate in discussions on policy would be a completely impractical way of running any political entity larger than a small city. (Athens' population was approximately 300,000 during its democratic phase, the number of people eligible to participate in its rule was much less.) Moreover, Dahl argues that even when meetings are small enough for complete participation to be possible, not everyone participates anyhow. Some people lack the confidence or social status necessary to participate, while others may feel intimidated by the complexity of issues involved. On the other hand, other members of society will be much more adept at participating, being either naturally confident or having a societal mandate to do so. These people will then tend to dominate meetings - in some cases they may do so in a relatively 'representative' manner expressing the concerns of a majority of the meeting's 'silent participants' but at other times they may well lobby largely in their own self-interest. Either way, some form of representation has, by default, occurred and through a manner that is potentially more opaque than that which occurs in representative democracy (voting) (Dahl 1989; Dahl 1998).

Despite these issues, Dahl (1998) does concede that it might be theoretically possible for some form of public meeting style democracy to function in a society where political power was decentralised enough to enable decision making to take place at the level of a small city state. However, he also points out that in a modern globalised world such decentralisation would be impractical because of the multitude of issues and inter-linkages (such as trade and pollution) which take place on a much larger scale than that of a city state. Rousseau himself seemed to become aware of the limitations of assembly type democracy and in his later writings admitted that, even for a small nation state such as Poland, some type of representative democracy would be needed (Dahl 1998). 
While Dahl did not dispute on principle Rousseau and Mill's belief that maximum participation would bring maximum public benefit (he was only disputing the practicalities of Rousseau's proposals), other democratic theorists such as Joseph Schumpeter have disputed even the desirability of maximum political participation. To Schumpeter, too much participation ran the risk of undermining organisational efficiency (Pateman 1970). "The electoral mass", Schumpeter argues, "is incapable of any action other than a stampede" (cited in Pateman 1970, p. 5). Schumpeter also argued that, while democracy was preferable to totalitarian rule, this was not because of any attributes inherent to participation, but rather because of the competition (for votes) that it caused between different parties of ruling elites (much in the same way that competition in markets is supposed to lead to optimal outcomes in economics) (Pateman 1970). To Schumpeter, the public's role in representative democracy was, quite rightly, limited to choosing between different ruling groups.

While Schumpeter's analysis of representative democracy as essentially being a contest between different groups of ruling elites would appear to be an accurate description of many modern democracies, there is still much debate as to the desirability of this. The argument for fostering increased democratic participation - or for creating systems that foster increased democratic participation - has received particular attention especially from left wing academics and activists attempting to find alternatives to both the limitations of representative democracy, and the limitations of totalitarian regimes associated with communism (Wainwright 2003). Some authors such as Carole Pateman (1970) and Michael Albert (2003) have proposed that problems of participation might best be solved by not only opening the political process but also by making other areas of society (such as industrial relations) more participatory as well. (Pateman suggests worker owned firms, while Albert advocates participatory economics.) Other authors such as Benjamin Barber (1984) and Hilary Wainwright (2003) have explored options for increased participation in the political sphere. (Their definitions of what constitutes 'the political sphere', it should be noted, are both fairly broad including community organisations.) German political philosopher, Jürgen Habermas, has proposed what he calls 'deliberative democracy' as an alternative democratic system (Avritzer 2002; Kapoor 2002).

The alternatives that both Barber and Wainwright explore involve increasing participation and changing the way that people participate in democracies by integrating the traditional political party representative systems with smaller scale community based schemes 
(Barber 1984; Wainwright 2003). Both authors see this 'deepening of democracy' as a way of empowering ordinary citizens and making them more aware of social issues. Wainwright's main focus, however, is on re-invigorating the state as an alternative to the free-market approach of neo-liberalism. While Barber, on the other hand, places significant emphasis on the role of increased democratic participation in creating a sense of community and elevating people above conventional 'us verses them' ways of thinking (Barber 1984; Wainwright 2003).

Habermas' proposal involves creating a 'public sphere' outside of both the economy and the state. Habermas envisages this public sphere as a space within which members of society can discuss, deliberate and decide upon issues in a manner that neutralises hierarchies of power. To Habermas, this type of deliberative process offers the best and most democratic manner of encouraging reasoned decision-making (Avritzer 2002; Kapoor 2002).

\subsection{What is Participatory Democracy?}

Historically, the term Participatory Democracy has been linked to Rousseau's proposals for direct assembly-style democracy. However, in recent years, Participatory Democracy has started to be used in a more broadly inclusive sense; one which covers many different proposals all linked by the common goal of creating a political system that allows greater citizen participation than current systems of representative democracy (Cabannes 2004; Dahl 1989; Dahl 1998). I have used the term Participatory Democracy in this dissertation because it is the term most commonly used by researchers to describe the participatory budgeting processes in Porto Alegre and Belo Horizonte. (For examples of this refer to the English and Portuguese research libraries at the Federal University of Minas Gerais' Democracia Participativa website - www.democraciaparticipativa.org).

\subsection{Development and Participation}

Like the field of democratic theory, the area of development studies has also seen a rise in activist and academic interest in the potential of increased participation in decisionmaking processes. Calls for increased participation in development started in the 1970s primarily as a response to the 'top-down nature' of conventional development (Brohman 1996). Advocates of participatory development called for an increased role for the people affected by development projects in the design, decision-making and implementation of these projects. As with the case put forward for participation in the democratic process, 
arguments in favour of participation in development can broadly be grouped into three categories - rights based, instrumental and developmental.

In its 1984 paper the United Nations Centre for Human Settlements (UNCHS) states succinctly the rights based argument for participation in development: "[p]eople have the right and duty to participate in the execution (i.e., planning, implementation, and management) of projects which profoundly effect their lives" (UNCHS 1984, p. 6). The logic is very similar to the philosophical argument in favour of democratic participation: if a series of events has a significant effect on a person or group then they should have the right to some say in the decision making process about these events.

There are two different instrumentalist arguments for participation in development. The first is that development projects take place amongst the complexities of developingworld life and these complexities are rarely completely understood by development practitioners who typically come from developed world countries (or more affluent sectors of developing countries' societies) and who may only spend a limited amount of time in the area that a project is proposed to take place. On the other hand, advocates of participatory approaches to development argue, people living in the area affected by a project will often have an intricate, intimate understanding of the area's realities and, as such can have an important input in designing a successful project (Brohman 1996; Chambers 1998). In addition to this, given that they are probably acutely aware of the problems they face on a day-to-day basis, the recipients of development projects are probably also fairly knowledgeable about what type of assistance they actually need (UNCHS 1984).

The second instrumentalist argument for participatory development is that it provides a balance to any potential abuse of power by government bureaucrats, politicians or international organisations in the design and implementation of development projects. The history of mainstream development has been punctuated by numerous examples of governments and developmental organisations implementing aid projects with anything but altruistic motives and the consequences of this have, too often, been disastrous for the recipients of this aid (for examples see Hancock 1989). Proponents of participatory development argue that by opening up the development process to the scrutiny of its recipients the potential for corruption and misuse of funds will be lowered.

The developmental case for participation in development is, in part, an instrumentalist one as well. From a developmental perspective, participation in aid projects is considered 
beneficial because it is hoped that, by having a greater say in the development of a project people are more likely to take an active interest in the success of the project. In addition to this, it is claimed that the increased knowledge participants obtain through the process of the design of the project, along with the experience they gain in articulating their concerns to outside agents, will assist in empowerment and personal development (Brohman 1996).

While there would seem to be considerable sense in the arguments made for participatory development, it has not always been successful in practice and this, along with the inherently contentious nature of development, has meant that the concept has been strongly criticised in recent years.

The main criticisms that have been levelled at participatory development are as follows:

- Co-optation - Critics charge that the concept of participation is easily co-opted and that often the term is applied to projects where participation is largely only cosmetic (i.e. the process is still 'top-down' and participant input is only trivial). In other cases, critics argue, participation is limited only to the implementation phase of the project and is not extended to the decision-making. It is possible in this case that participation is just being used as a means of making a local population more agreeable to a project that they might otherwise object to (Cook \& Kothari 2001).

- Ignores Macro Processes - Another criticism of participatory development is that it focuses too exclusively on project level development issues and, as such, may lead to development practitioners ignoring important macro issues that may significantly offset any benefits the project has to offer. Critics also charge that a focus on participatory projects diverts attention from larger macro-economic injustices that have significant effects on the lives of people in the developing world (Kapoor 2002).

- Ignores Local Power Dynamics - A further, strong criticism of participatory development is that the process is often blind to power hierarchies that exist within participating communities. In some cases community structures may only really allow for the effective participation of people of certain social status or gender meaning that there still exists a risk of projects' benefits being captured by a relatively small sector of a community (Cook \& Kothari 2001).

- Need for Outside Expertise - A final criticism of participatory development is that it can potentially idealise local knowledge at the expense of undervaluing just what outside expertise can add to a project (Baierle 2003). 
While all of these criticisms are valid to an extent, defenders of participatory development have made the point that none of them completely invalidates participatory development. The charge of co-optability, they argue, does not actually highlight anything that is inherently wrong with participatory development, but rather makes a more general point that, like any development tool, the concept can be used in a disingenuous manner. And, they argue, the other three criticisms highlight pitfalls that participatory practitioners need to be wary of, rather than inherent flaws of the concept (Brohman 1996; Chambers 1998).

\subsection{Conclusion}

Politics and Development are inextricably linked so it is unsurprising that there are similarities between the arguments for participation in politics and the arguments for participation in development. Along with an overall outline of democratic theory, this chapter has examined the case for increased participation in the democratic process as well as the case for increased participation in development. The arguments presented so far have been general ones and not country-specific. The following two chapters move away from theory and attempt to provide background of a different nature. The first details the political history and culture of Brazil, and the second discusses the nature of the PT (the party responsible for implementing the participatory budget). The issues of democracy, development and participation raised in this chapter will be re-addressed in the results, discussion and conclusion of this dissertation where it will be explained how the participatory budgets of Porto Alegre and Belo Horizonte inform and are informed by these theoretical ideas. 


\section{Chapter 4 - Brazilian Political History}

\subsection{Introduction}

"I will do everything for the people and nothing by the people." Brazilian emperor Dom Pedro resisting constitutional reforms, cited in Smith 2002, p. 47.

There are two aspects of Brazilian politics that are particularly relevant to this study of Participatory Democracy. The first is the extremely inegalitarian distribution of political and economic power that has become synonymous with Brazil, and the second is the relatively high degree of autonomy that is granted to states and municipalities in Brazil. The roots of both these political characteristics can be traced all the way back to Brazil's founding and, as this chapter will show, the characteristics have remained salient features of the country's political landscape throughout the intervening years.

\subsection{Early Political History}

The first Portuguese colonists - who arrived in Brazil in the 1530s - were confronted by a vast resource rich land. Positions of power in the new colony were by royal appointment and initial settlement took place predominantly in the Northeast, where the sheer amount of land available to the new colonists, combined with the relatively small initial number of colonials and Portugal's mercantilist designs, meant that the new colony's arable land was partitioned into large extractive estates (Fausto 1999). Elizabeth Bradford Burns (1980, p. 31) notes in her history of Brazil that:

\footnotetext{
Because Brazil was vast and the colonists few he [Martim Afonso one of Brazil's 'founding fathers'] distributed the land with lavish generosity... the latifunda [large farm estate] which originated at the birth of the colony remained as a dominant characteristic of Brazil.
}

Such large estates required labourers. However, the colonials themselves were a reluctant workforce (Bradford Burns 1980) and, furthermore, were often rendered incapable of strenuous physical work by the Brazilian Northeast's tropical disease environment (Crosby 1986; Sokoloff \& Engerman 2000). As a consequence of this, the Portuguese initially looked to Brazil's indigenous populations to provide forced (enslaved) labour on the estates. Yet indigenous Brazilians often proved to be uncooperative slaves and their numbers were greatly reduced by epidemics of disease in the later half of the $16^{\text {th }}$ Century. 
In addition to this, the indigenous population received some protection from the Portuguese crown as well as from the church (the Jesuits were particularly vociferous in their support of indigenous emancipation for which they were rewarded by expulsion from Brazil in 1759). For these reasons, plantation owners increasingly looked to slaves from Africa as a source of their labour and by the 1630s Africans greatly outnumbered indigenous Brazilians on the plantations (Skidmore 1999; Smith 2002). As well as being few in number, the early Portuguese colonies were also isolated from each other. As a result of this, many of the early settlements had better communications links with Portugal than they did with the other settler communities (Fausto 1999).

From the colony's founding until the $19^{\text {th }}$ Century, economic and demographic growth continued relatively slowly. Economic growth was based primarily around plantation agriculture with the only major exception to this being the gold rush in Minas Gerais State. Throughout this period of time Brazilian society remained highly stratified: slaves at the bottom, and free Africans and indigenous people above them. Slightly better off were a 'middle class' of mixed race people. Presiding at the top of the social pyramid were Portuguese and Brazilians with 'pure' Portuguese ancestry (Bradford Burns 1980; Skidmore 1999). The distribution of political power reflected this social stratification with power residing entirely in the hands of Portuguese administrators and white landowners. Society was non-democratic and only the elites had any opportunity to participate in the political process. The other dominant feature of colonial Brazil's political structure was the relative degree of political autonomy experienced by the country's different regions. This political autonomy was, in part, the result of Brazil's size, which effectively limited central control (Smith 2002).

\section{3 'Imperial’ Brazil and the First Republic}

In 1807, acting on the orders of emperor Napoleon, French forces invaded Portugal. To evade capture by the French, the prince regent Dom Juão fled to Brazil, landing in Bahia on January 22, 1808, and then moving to Rio de Janeiro, which became the capital of the Portuguese empire (Fausto 1999).

In practice, Dom Juão's stay in Brazil did little to change the hierarchical distribution of power there. The only real change resulting from his presence was the transfer of some power from Brazilian elites to newly arrived Portuguese courtiers (Smith 2002). 
When he departed, Dom Juão left his son Pedro in Brazil. Pedro's presence in Brazil did not, however, cement the colony's ties to Portugal. Instead, Pedro soon became a focal point of the country's growing independence movement and it was Pedro who declared Brazil's independence on 7 September 1822 (Skidmore 1999). Under Pedro, Brazil remained a monarchy (nominally an empire with Pedro crowned Pedro I Emperor of Brazil). The reign of Pedro I was followed by a period of regency and then by the rule of his son Dom Pedro II. During the reign of Pedro II, Brazil's political system resembled the parliamentary constitutional monarchy that existed in Britain at the time and the beginnings of a party political system began to arise with debate taking place between those who called for some constitutional reform and those who supported the monarchy. Brazil's nascent politics remained elitist though; political influence was limited to the landed oligarchy and wealthy merchants, and no attempt was made to represent lower socio-economic groups (Bradford Burns 1980). Slavery was abolished in 1888 yet its legacy remained in the form of the political and economic disenfranchisement of the slaves' descendants (Fausto 1999). While political exclusion remained constant in Imperial Brazil, the degree to which political power was centralised fluctuated, with there being persistent tension between conservative forces who favoured a more centralised government and liberals who called for more regional autonomy. Decentralising tendencies culminated in a series of wars as various states declared independence and had to be forcibly 'reintegrated' back into Brazil. In a response to the state rebellions, Pedro II made concerted efforts to centralise power (Skidmore 1999).

In 1889 the Brazilian military engaged in its first major foray into politics when it toppled the waning monarchy in a coup and declared Brazil a republic. While the coup was ostensibly based around overthrowing the monarchy in favour of democracy and liberal ideals, and while the country's first civilian president was elected in 1895, the reality of post coup life was that "elitism and conservatism dominated political life...just as they had during the empire" (Smith 2002, p. 89). A new constitution did, in theory, offer universal manhood suffrage. However, a literacy requirement still denied most male Brazilians the vote and election votes were cast in public, giving local elites ample opportunity to coerce voters. In addition to this, congressional committees vetted election results at the state level, sifting out any potential dissidents (Bradford Burns 1980; Smith 2002).

While ideas of succession had largely been quashed, the first republic was a period of considerable autonomy for Brazil's individual states. Within the states the distribution of political power was almost identical to that at a federal level: a small, very wealthy sector of society was able to manipulate politics to ensure that they remained in power, and that 
they benefited from it. State level politicking became dominated by clientelism and patronage; governors provided jobs and favours to local landholders in return for votes at election time (Skidmore 1999, Smith 2002).

The military never remained far from politics during the first republic, and in 1930 it intervened directly again deposing President Washington Luís and installing Getúlio Vargas to power (Bradford Burns 1980; Fausto 1999; Smith 2002). Vargas was a charismatic politician from the state of Rio Grande do Sul, who often used populist rhetoric in his speeches and had liberal tendencies, yet his elevation to power was not the result of a 'peoples' revolution' but rather that of a struggle for power between different states. Vargas' first act in power was to suspend the 1891 constitution, thus bringing to an end the First Republic (Fausto 1999).

\subsection{Vargas, the Second Republic and the Return to Military Rule}

Once in power, Vargas seemed to shed his liberal beliefs and went about governing the country in a dictatorial fashion. During his rule, presidential elections ceased and press freedoms were suppressed; Vargas was also ruthless in his crushing of the newly formed Brazilian Communist and Fascist Parties. At a social and economic level Vargas did pay some attention to the working classes, establishing a minimum wage and some social programmes for industrial workers, yet he avoided any radical policy changes such as land reform that might have alienated him from the oligarchs (Bradford Burns 1980; Smith 2002). The Vargas era also saw a marked decrease in autonomy at the state level as Vargas centralised political power under his control (Skidmore 1999).

Despite his authoritarian tendencies, Vargas remained popular in Brazil and, after the military forced Vargas to hold democratic elections (in which he did not stand for president), he was elected governor of Rio Grande do Sul in 1945. He then went on to win the Brazilian presidential elections of 1950 (Smith 2002). Vargas ruled until 1954 when, under pressure from the military, he resigned and committed suicide. Vargas' resignation was followed by presidential elections in 1955, which were won by Juscelino Kubitshek. The years that Kubitshek spent in office were characterised by impressive state led economic growth that came at the expense of increasing government debt and high inflation. Like Vargas, Kubitshek paid some attention to the worker welfare, negotiating an increase in the minimum wage. However, like Vargas, Kubitshek also steered clear of any major structural reforms that may have alienated the ruling classes (Smith 2002). 
Kubitshek's term in office was followed by that of Jânio Quadros who resigned after only seven months in power making way for João Goulart, the left leaning vice president, to take power. Goulart's time in power was marked by a decline in relations with the United States and a corresponding warming of relations with the USSR and China (these trends had begun under Quadros). On the economic front, Goulart continued with policies of state-led growth, with the consequences of high inflation and increasing budget deficits. Most controversially, and for the first time in Brazil's history, Goulart passed legislation bringing about significant agrarian land reform. In many ways Goulart was merely following a slightly more radical form of Vargas' populism, however, unlike Vargas who was an astute political manoeuvrer, Goulart alienated the ruling oligarchy and much of the military. Consequently he was deposed in a military coup in $1964^{4}$ (Branford \& Kucinski 2003; Smith 2002).

Unlike its intervention in 1954, when the military had stepped in to unseat an increasingly dictatorial Vargas and then handed power back to civilian leaders, the coup in 1964 reflected the military's increasing frustration with the electoral process. Once they obtained power they showed little inclination to relinquish it and, while they were not quite as bloodthirsty as some of their Latin American counterparts, the Brazilian Junta set about suppressing any political dissent with vigour (Branford \& Kucinski 2003; Fausto 1999; Keck 1992).

Facing repression, some sectors of the left took to armed rebellion, which the military responded to by further suspending civil liberties and engaging in disappearances and torture (Skidmore 1999). The military also continued the re-centralisation of political power that had started under Vargas. Economically the dictatorship continued to follow state led growth models and, for a time, they were more successful than the civilian leaders had been at generating sustained growth while containing inflation. Import substitution and the encouragement of export diversification via subsidies were central aspects of the military government's economic policy (Fausto 1999; Skidmore 1999). However, economic growth was matched by growing income inequality and as a consequence life for many of Brazil's poor was little changed. Furthermore, growth came at the expense of debt and, when the 'global credit crunch' occurred in the late 1970s

\footnotetext{
${ }^{4}$ Bradford Burns (1980) notes that the coup to unseat Goulart was not entirely the result of internal pressures, with the US government (specifically the CIA) playing a role in the overthrow of his administration. Four hours after the coup was staged the Brazilian Junta received a telegram from US president Johnson congratulating them on their manoeuvre.
} 
Brazil's economy rapidly stagnated (Skidmore 1999). This economic stagnation, along with continued repression, began to alienate the middle classes as well as some of the ruling elite and the Catholic Church and, as a consequence of this, facing considerable public pressure, the army began a slow re-democratisation process (Bradford Burns 1980).

\subsection{Return to Democracy}

In 1982, military leader João Figueiredo, whose rule had been dramatically undermined by the revelation that the military had been involved in planting bombs that had killed civilians, allowed elections to be held for Congress, state governors and municipalities. These elections were followed by restricted presidential elections in 1985 in which, for the first time in over two decades, neither candidate was a military officer. In 1988 Brazil enacted a new constitution - one which formally marked the return to democracy and the end of direct military involvement in politics (Fausto 1999).

\subsection{Brazil's Current Political System}

Brazil's new constitution made the country a federal republic with the president being directly elected by the populace every five years. The constitution granted universal suffrage to everyone over the age of 16 (there is no literacy requirement) and all political parties were made legal (Central Intelligence Agency 2004; Sader \& Silverstein 1991). While some changes have been made to it since 1988, the 1988 constitution is the constitution that Brazil currently operates under. Under the new constitution the executive powers of the president are balanced by the legislative power of the congress. The congress itself is split into the Federal Senate and the Chamber of Deputies. The Senate contains 81 senators in total - three senators from each state as well as three from the Federal District (the city of Brasilia and its hinterlands) (Martins \& Milton Schneider 2004). There are 513 members of the Chamber of Deputies. Both Senators and Deputies are directly elected by the public. The number of Deputies allocated to each state is, in theory, decided in proportion to the state's population, however, because the maximum number of Deputies from any one state is 70, more populous states such as São Paulo are underrepresented (Central Intelligence Agency 2004, Martins \& Milton Schneider 2004).

The president is relatively powerful in comparison to the legislature and can propose bills to the congress which the congress must ratify within 30 days, while the president can also veto any bill proposed by the congress. Congress can, however, override presidential veto, within 30 days, by an absolute majority vote (Martins \& Milton Schneider 2004). 
The new constitution also brought about significant decentralisation of government, increasing the powers granted to Brazil's 26 individual states, particularly in the area of revenue collection. This measure was broadly approved of by pro democracy activists (who associated centralisation with dictatorship) and by existing political elites who saw increased revenue for state governments as an opportunity to cement their hold on power through clientelistic exchanges (Abers 2000; Martins \& Milton Schneider 2004). In addition to making the states largely responsible for their own financial affairs, the new constitution also provided the states with considerable political autonomy; states were required to enact their own constitutions as well as establish their own justice systems. Under the new constitution states were ruled by a directly elected governor and legislature (Martins \& Milton Schneider 2004).

The new constitution also divested significant power to a municipal level. Municipalities were able to raise their own revenue through property taxes and also received tax transfers from state governments and, in some circumstances, from the federal government. Brazilian municipalities are governed by a mayor and city council; as is the case with the federal executive, the mayor can veto any council legislation, however, the council can override the mayor's veto with a two thirds majority (Abers 2000; Martins \& Milton Schneider 2004; Marcelo Kunrath Silva, interview notes).

\subsection{Democratic Brazil}

In 1989 Brazil held direct presidential elections completing the return to democracy (Sader \& Silverstein 1991). Yet a return to democracy did not mark an end to elite dominated politics. Instead, from the first (partially democratic) elections in 1985 through to 2002, Brazil continued to elect presidents who came from the traditional ruling classes (Keck 1992; Sader \& Silverstein 1991; Skidmore 1999). Politicians often used populist rhetoric on the campaign trail yet, once in power, they proved to be reluctant to make any significant social reforms (Branford \& Kucinski 2003; Sader \& Silverstein 1991). The first (indirectly) elected president, Tancredo Neves, died on the eve of his inauguration in 1985. Neves was replaced by his deputy José Sarney who was always regarded with suspicion as, until very late in the dictatorship, he had been supportive of the military. The later half of Sarney's term in office was blighted by economic crisis and ineffective leadership, and Sarney was deeply unpopular by the time direct elections took place in 1989 (Branford \& Kucinski 2003; Skidmore 1999). 
Sarney was replaced by Fernando Collor de Mello, who came to power promising to tame the 'jungle of Brazilian capitalism' and to cleanse Brazil of corruption. Collor presented himself as a Social Democrat in elections, however, the political party he represented, the Partido de Reconstrução National was, in reality, right leaning and Collor was ultimately impeached by congress for, of all things, corruption (Branford \& Kucinski 2003; Skidmore 1999; Smith 2002).

Following Collor's downfall, Fernando Henrique Cardoso, the architect of the successful 'Real Plan' for reducing inflation, was elected to power. Cardoso's initial successes with inflation was augmented by legislation to raise the minimum wage and some other social programmes, meaning that Cardoso ended his first term in office still highly popular. $\mathrm{He}$ was even able to amend Brazil's constitution so that he could run for presidency a second time in 1998. Along with a focus on low inflation, Cardoso adopted other neo-liberal economic policies - state-owned assets were sold off, attempts to balance the federal budget undertaken, and the Brazilian economy was opened extensively to world markets (Skidmore 1999; Branford \& Kucinski 2003) ${ }^{5}$.

Cardoso was then successful in his second bid for power, however, shortly after the election the Brazilian economy, buffeted by external crises, collapsed. (Some authors have claimed that an International Monetary Fund (IMF) loan, which propped up the Brazilian economy and staved off collapse until after the elections, was given in a politically motivated manner; designed to keep the economy afloat long enough for Cardoso to win re-election (Branford \& Kucinski 2003; Palast 1999). In his second term, Cardoso was dogged by political scandal and evidence of corruption amongst his political apparatus. Furthermore, Cardoso's neo-liberalism did not decrease inequality in Brazil and in some ways made life worse for Brazil's poor (Baierle 2003; Bellos 2000; Branford \& Kucinski 2003).

In general, the political exclusion of post dictatorship Brazil was reflected by a continuation of economic exclusion; Brazil's highly skewed distribution of wealth remained at levels similar to that of the dictatorship years (see table 4.1).

\footnotetext{
${ }^{5}$ Cardoso's zeal for trade liberalisation represented something of an about face as he had once been a left leaning dependista sociologist who had argued for an end to Brazil's dependence on international markets.
} 
Brazil currently has the world's fourth most unequal distribution of income, with a GINI coefficient of $60.7^{6}$ (Central Intelligence Agency 2004).

Table 4.1 - Brazil's Income Distribution Amongst the Economically Active Population

\begin{tabular}{|l|c|c|c|c|c|}
\hline Income Group & $\mathbf{1 9 6 0}$ & $\mathbf{1 9 7 9}$ & $\mathbf{1 9 9 0}$ & $\mathbf{1 9 9 5}$ & $\mathbf{1 9 9 9}$ \\
\hline Poorest 20\% & $3.5 \%$ & $1.9 \%$ & $2.1 \%$ & $2.3 \%$ & $2.3 \%$ \\
\hline Poorest 50\% & $17.7 \%$ & $11.9 \%$ & $11.3 \%$ & $12.3 \%$ & $12.6 \%$ \\
\hline Richest 20\% & $54.3 \%$ & $64.2 \%$ & $65.6 \%$ & $64.2 \%$ & $63.8 \%$ \\
\hline Richest 10\% & $39.6 \%$ & $47.6 \%$ & $49.1 \%$ & $47.9 \%$ & $47.4 \%$ \\
\hline Richest 1\% & $11.9 \%$ & $13.4 \%$ & $14.2 \%$ & $13.9 \%$ & $13.3 \%$ \\
\hline
\end{tabular}

Source: Branford \& Kucinski 2003, p. 98

\subsection{Conclusion}

As this chapter has shown, Brazil's political history has seen much change: the country has been a colony, an empire, a republic, a military dictatorship and a democracy. Political power has been highly decentralised at times and centralised at others. Yet throughout all this change, from the founding of the country up until 2002, one thing has remained remarkably constant: the concentration of political power in the hands of the elite.

However, in the presidential elections of 2002 all this changed; for the first time in the country's history the Brazilian electorate elected a leader from a working class background. Luis Inácio da Silva (Lula), the victorious presidential candidate, grew up in extreme poverty in Brazil's Northeast and had worked as a steelworker before entering politics (Branford \& Kucinski 2003). What is more, the party he represented - the PT was primarily a party of the working class and campaigned on a pro-working class platform. The following chapter details the rise of the PT, analyses the nature of the party and examines its experiences in both federal and municipal government.

\footnotetext{
${ }^{6}$ The Gini coefficient measures the degree of inequality of the distribution of family income in a country. The Gini coefficient is calculated first by plotting the Lorenz Curve of a country's income distribution (in a Lorenz Curve, cumulative family income is plotted against the number of families arranged from poorest to richest). The Lorenz curve is then compared to a 45-degree 'helper line' (which represents a perfectly even income distribution) and the Gini coefficient itself is the ratio of the area between the Lorenz Curve and this helper line, taken against the area under the helper line. A Gini coefficient of Zero represents perfect income equality while a Gini coefficient of 1 represents perfect income inequality.
} 


\section{Chapter 5 - The PT in Opposition and in Power}

\subsection{Introduction}

The chapter that follows continues the task, started in the previous chapter, of placing Porto Alegre and Belo Horizonte's experiments in Participatory Democracy within the context of the broader political reality that they operate in. In the previous chapter a broad overview of Brazil's political history was given; in particular, the reader's attention was drawn to the fact that - from the country's founding up until almost the present day politics in Brazil have been dominated by a small wealthy sector of society. Now I move on to detail the rise of the PT (the political party responsible for introducing the participatory budget to Porto Alegre and Belo Horizonte) and explain how they have come to challenge the elite domination of Brazilian politics. I also detail the PT's experience in municipal governance in Brazil - highlighting the often un-solvable dilemmas that the party has encountered when it has won municipal power.

\subsection{The Rise and Rise of the Partido dos Trabalhadores}

"It's time to finish with the ideological rustiness and self-indulgence of those who sit at home reading Marx and Lenin. It's time to move from theory to practice. The Workers' Party is not the result of any theory but the result of twenty four hours of practice" (Lula cited in Sader \& Silverstein 1991, p. 50).

Collectively referred to as the 'ABCD suburbs', the municipalities of Santo André, São Bernado do Campo, São Caetano and Diadema were the focal point of the rising industrial worker militancy that took place in the late 1970s in Brazil. The municipalities form part of the greater São Paulo metropolis and, as Brazil industrialised after the Second World War, became the centre of Brazil's steel working industry. For Brazil's industrial workers the years of military dictatorship were particularly tough; wages failed to keep up with inflation and workers found their spending power significantly reduced. In 1978 strikes broke out, first in the ABCD cities and then across São Paulo state, affecting 300 factories and involving as a many as 300,000 workers (Branford \& Kucinski 2003; Sader \& Silverstein 1991).

Workers went on strike again in 1979 , and this time the strikes spread to 15 states and expanded beyond metal workers to include urban service workers, textile workers, miners, bank workers, construction workers and teachers (Keck 1992). At the centre of the strike 
were new trade unions that had formed as a result of Brazilian workers' frustration with the existing union structure, which did little more than provide social services to its members, and was, typically, easily coerced by the state and employers (Keck 1992).

It was the leaders of these new trade unions who were instrumental in forming the PT realising that "they [union leaders] had to participate in politics, because within the current union structure, they had already tried everything possible to improve conditions for workers, and failed." (Lula - who was a São Bernado Metal Worker's union leader cited in Keck 1992, p. 69).

While the PT was formed initially by trade unionists, its founding fathers decided the party should remain autonomous from the union movement. Unlike the European working class parties, which formed during the first half of the $20^{\text {th }}$ century, the PT was not funded by labour unions nor did it automatically acquiesce to their demands (indeed, as will be discussed later, PT municipal governments have often come into conflict with unions representing state employees). The PT was founded with the intention of providing political space for social movements yet it remained its own entity, separate and able, potentially, to act independently of them (Keck 1992).

In addition to this, the decision was made at the party's founding that the party should be explicitly a party of the working class. This decision was important in that it alienated the party from politicians such as Fernando Cardoso (the future president) who wanted to build a broad-based opposition party and also because it meant that Brazil, for the first time in its history, had a major political force, with a significant proportion of working class leaders, geared around addressing issues affecting Brazil's poor. Previous politicians such as João Goulart and Getúlio Vargas had from time to time addressed socio-economic issues but had tended to do so in a populist top-down manner aimed, particularly in Vargas' case and not so successfully in Goulart's, at cementing their own hold on power. Significantly, both Vargas and Goulart had come from Brazil's political elite; Lula, by

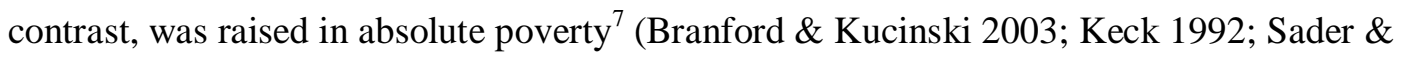
Silverstein 1991).

In addition to decisions made by the party's members at its inception, several external factors played an important role in determining the nature of the fledgling PT. A particularly important external factor was the state of the radical Brazilian left at the end

\footnotetext{
${ }^{7}$ Carlos Prestes' Communist Party was for a time a significant political force. However, Prestes himself was a senior army
} officer and the Communist Party generally sought compromise with other political parties. 
of the 1970s. Under the military regime the radical left, which had never had the same strength in Brazil as it did in some other Latin American countries, was almost completely decimated by the repressive acts of the Junta. This meant that the union members and social activists who founded the PT had few ties to the country's 'old left' and, as such, were not encumbered by any particular ideology other than a commitment to social justice. They were also more inclined to be pluralistic and tolerant of different ideological perspectives within their party (Sader \& Silverstein 1991).

Such pluralism, along with the fact that the party was not linked exclusively to the trade unions, meant that the party was able to become home for a broad base of different social activist groups; Maoist groups have co-existed with Social Democrats as well as Catholic Church activists and Rural Movements such as the Movimento Sem Terra (Land-less Workers Movement, hereafter MST) (Branford \& Kucinski 2003). This internal diversity has proven, over the years, to be both a strength and a source of problems for the PT. Diversity has enabled the party to benefit from the activism of numerous social groups yet, at the same time, it has caused conflict within the party, particularly between moderate and radical tendencies (Branford \& Kucinski 2003; Keck 1992; Sader \& Silverstein 1991). Another important external factor that influenced the PT's choice of tactics was the increasingly apparent failure of the 'socialist revolution' in Eastern Europe (Sader \& Silverstein 1991). In particular, the failures of the totalitarian regimes in Eastern Europe convinced the PT's leaders that socialism, if it was to succeed, needed to be coupled with democracy (Branford \& Kucinski 2003).

In the years following the PT's creation, as Brazil gradually re-democratised, the PT contested first municipal, then state, then national elections. Despite some municipal victories, results from early elections (particularly 1982 and 1986) were considered disappointing by many party activists. And, consequently, the party began a process of attempting to appeal to a wider sector of Brazilian society (primarily this was done by softening its radical rhetoric) (Branford \& Kucinski 2003).

At the same time as it began to pitch its message to a wider section of Brazilian society, the party began to benefit from the campaigning of its activists as well as from an electorate that was becoming increasingly frustrated with traditional politicians and which began to view the PT as an oasis of integrity in the corrupt swamp of Brazilian politics (Branford \& Kucinski 2003). Accordingly the PT began to experience increasing electoral success, initially at the municipal level but also in state and national elections (see tables 4.2, 4.3 and 4.4). 
Table 4.2 - PT Results in Brazilian Municipal Elections

\begin{tabular}{|c|c|c|}
\hline Year & $\begin{array}{c}\text { Number of PT } \\
\text { Mayors }^{8}\end{array}$ & $\begin{array}{c}\text { Number of PT } \\
\text { Councillors }\end{array}$ \\
\hline $\mathbf{1 9 8 2}$ & 2 & 127 \\
\hline $\mathbf{1 9 8 8}$ & 37 & 1006 \\
\hline $\mathbf{1 9 9 2}$ & 54 & 1100 \\
\hline $\mathbf{1 9 9 6}$ & 115 & 1895 \\
\hline $\mathbf{2 0 0 0}$ & 174 & 2475 \\
\hline
\end{tabular}

Source: Branford \& Kucinski 2003, p. 55

Table 4.3 - PT Results in State Elections

\begin{tabular}{|c|c|c|}
\hline Year & $\begin{array}{c}\text { Number of PT } \\
\text { Governors }\end{array}$ & $\begin{array}{c}\text { Total Number of } \\
\text { Governors }\end{array}$ \\
\hline 1982 & 0 & 27 \\
\hline 1986 & 0 & 27 \\
\hline 1990 & 0 & 27 \\
\hline 1994 & 2 & 27 \\
\hline 1998 & 3 & 27 \\
\hline 2002 & 3 & 27 \\
\hline
\end{tabular}

Source: Branford \& Kucinski 2003, p. 55; Central Intelligence Agency 2004, p. 1

Table 4.4 - PT Results in National Congressional Elections

\begin{tabular}{|c|c|c|c|c|}
\hline Year & $\begin{array}{c}\text { Number of } \\
\text { PT seats in } \\
\text { the } \\
\text { Chamber of } \\
\text { Deputies }\end{array}$ & $\begin{array}{c}\text { Percentage of } \\
\text { total seats in the } \\
\text { Chamber of } \\
\text { Deputies held by } \\
\text { the PT }\end{array}$ & $\begin{array}{c}\text { Number of } \\
\text { PT } \\
\text { Senators }\end{array}$ & $\begin{array}{c}\text { PT Senators as } \\
\text { a percentage of } \\
\text { the total } \\
\text { number of } \\
\text { Senators }\end{array}$ \\
\hline $\mathbf{1 9 8 2}$ & 8 & $1.7 \%$ & 0 & $0.0 \%$ \\
\hline $\mathbf{1 9 8 6}$ & 16 & $3.3 \%$ & 0 & $0.0 \%$ \\
\hline $\mathbf{1 9 9 0}$ & 37 & $7.0 \%$ & 1 & $1.2 \%$ \\
\hline $\mathbf{1 9 9 4}$ & 50 & $9.6 \%$ & 5 & $6.2 \%$ \\
\hline $\mathbf{1 9 9 8}$ & 60 & $11.3 \%$ & 8 & $9.9 \%$ \\
\hline $\mathbf{2 0 0 2}$ & 91 & $17.7 \%$ & 14 & $17.3 \%$ \\
\hline
\end{tabular}

Source: Branford \& Kucinski 2003, p. 43; Martins \& Milton Schneider 2004, p. 1

\footnotetext{
${ }^{8}$ There are approximately 5000 municipalities in Brazil (the exact number changes frequently).
} 
Along with contesting municipal, state and congressional elections, the PT has, from 1989, contested the Brazilian presidential elections. The PT's performance in presidential elections is shown below in Table 4.5.

Table 4.5 - PT Results in Presidential Elections

\begin{tabular}{|c|c|c|c|c|}
\hline Year & $\begin{array}{c}\text { First Round: } \\
\text { Votes }\end{array}$ & $\begin{array}{c}\text { First Round: Votes } \\
\text { as Percentage of } \\
\text { Total Vote }\end{array}$ & $\begin{array}{c}\text { Second Round: } \\
\text { Votes }^{9}\end{array}$ & $\begin{array}{c}\text { Second Round: } \\
\text { Votes as } \\
\text { Percentage of } \\
\text { Total Vote }\end{array}$ \\
\hline $\mathbf{1 9 8 9}$ & $11,622,000$ & $16.0 \%$ & $31,000,000$ & $44.2 \%$ \\
\hline $\mathbf{1 9 9 4}$ & $16,802,000$ & $22.0 \%$ & & \\
\hline $\mathbf{1 9 9 8}$ & $21,803,000$ & $26.1 \%$ & & \\
\hline $\mathbf{2 0 0 2}$ & $39,444,000$ & $46.4 \%$ & $57,200,000$ & $61.3 \%$ \\
\hline
\end{tabular}

Source: Branford \& Kucinski 2003, p. 43

The 1989 presidential elections were Brazil's first truly democratic presidential elections since 1964 (the 1985 elections were facilitated by an electoral college system that limited the political choice of voters) and they took place at a time when the electorate was still reeling from Sarney's economic crisis. A combination of democratic spirit and economic instability provided Lula (the PT's charismatic presidential candidate), and left wing parties in general, with an electoral boost. Polls taken in early 1989 showed Lula and another left wing candidate, Leonel Brizola, as the leading presidential contenders, each commanding about 12 percent support from voters polled. Yet, as always in Brazilian elections, the left wing candidates found themselves up against an entrenched elite and a powerful, mostly conservative, media who were able to propel Fernando Collor de Mello into front runner status by the time the election came around (Sader \& Silverstein 1991).

Collor de Mello won the first round of the presidential elections but was unable to get the 50 percent majority necessary to avoid second-round elections. In the second round, voters who had previously voted for Brizola and other left wing candidates pooled their votes behind Lula (who had finished second behind Collor in the first round vote) and, for a time before the second round election, it appeared that Lula might have enough support to win. However, once again, large sections of the media, in particular television stations and papers owned by media magnet Roberto Marinho, went on attack against Lula, and Collor won a narrow victory in the second round vote (Sader \& Silverstein 1991).

\footnotetext{
${ }^{9}$ Brazilian Presidential elections are conducted in a manner where, if no candidate receives a clear majority (over 50 percent) of votes in the first round of voting, a second round is held with the top two candidates from the first round contesting the ballot. If a candidate receives a clear majority in the election's first round, as Cardoso did in 1994 and 1998, no second round is held.
} 
In many ways the 1989 result, while a loss, indicated that the PT were a force to be reckoned with at a national level. It also cemented their place as the most significant left wing political party in the Brazilian Political landscape. Yet the party had to wait another 13 years before it had another serious shot at power. In both the 1994 and 1998 elections Fernando Cardoso won such convincing first round victories that the PT and Lula were unable to even force the election to a second round vote. While Cardoso's electoral victories were resounding, it is worth noting that the PT did increase the number of first round votes it received in each election. Furthermore, with each additional campaign the PT's organising skills and media savvy improved, while at the same time their grassroots campaigning gained the support of many of Brazil's disenfranchised. While it remained a separate entity from both the social movements and the unions, in practice PT members were often also members of these organisations - a fact which gave the PT a strong organisational base. In the cities, through the unions and other social groups, the PT was connected to the urban poor, while in rural areas alliances with groups such as the MST and Catholic Base communities gave the PT a connection to the country's rural poor. At the same time the PT had begun to gain a reputation (earned largely by the way it administered some of the municipalities in its control) as an efficient administrator and one, importantly, that was not corrupt. This factor assisted in its appeal to the middle class. In addition to this Lula adopted a conciliatory tone to the Brazilian elite meaning that some of them at least did not feel so threatened by the prospect of a PT president. These combined factors meant that Lula was able to win, comfortably in the end, the 2002 presidential elections. In terms of Brazilian political history, Lula's win was a true watershed; not only did the country have its first ever working class president, but PT government also meant that, for the first time, the country was ruled by a political party of the working class (Branford \& Kucinski 2003). This would appear to be a significant change in a country whose history has been dominated by the political exclusion of the masses and control of the political apparatus by a small elite.

Lula's victory was greeted by celebrations across Brazil. However, two years into its rule, his government is beset by problems. As a consequence of previous budget deficits and Cardoso's neo-liberalism, Lula has found himself dependent on an IMF bailout package, and forced to placate foreign investors lest he trigger capital flight. He has had to raise interest rates to stave of inflation (causing domestic recession and high unemployment) and the government is short of the money needed to undertake significant social programmes. Lula's apparent acquiescence to economic orthodoxy has alienated him from the party's left and dissent is on the rise. Furthermore, he has come into conflict with 
federal employees over state pensions and has had to deal with striking workers (Branford \& Kucinski 2003; Munk 2003).

In many ways these problems do not bode well for Lula and his hopes of political and economic reform. In addition to internal constraints and friction within his own party, he has to deal with the realities of the global economy. Still Lula has some reasons for optimism, the economy appears to be turning round (Munk 2003) and his voter approval rating has remained reasonable. Furthermore, his own party's experience in municipal governance (described in the next sub-chapters) suggests that it is possible for a reforming social government to overcome some of the difficulties associated with political power in Brazil and, at the same time, help the country's least well off.

\subsection{The PT and the Problems of Municipal Governance}

For the vast majority of Brazilian cities the process of urban development has been haphazard at best and disastrous at worst. Poor planning, rapid urbanisation, corrupt political elites and extreme inequality have left as their legacy cities that often suffer from inadequate provision of municipal services, that invariably contain sprawling favelas (slums), and which are presided over by city halls that are, in many cases, effectively bankrupt (Baiocchi 2003). Such cities provide a challenge to any political party trying to govern them, however, for the PT, which has campaigned on a socially reforming platform, the challenges have been particularly severe.

In 1982 the PT won its first two mayoralties in the cities of Diadema in São Paulo State and Santa Quitéria in Maranhão State, and (as was illustrated in Table 4.2) has won an increasing number of mayoralties in every election since then. While the numbers in Table 4.2 appear to tell a happy tale of increasing political success for the PT, in practice, municipal governance has been a rocky road for the party; one that has seen the PT often lose power after only one term in office and which has led to significant internal strife. Of the 36 mayors that the party had elected in 1989, 12 left or were expelled from the party before completing their term in office (Abers 2000; Baiocchi 2003; Keck 1992; Sader \& Silverstein 1991).

While the PT's problems in power have been, in part, the result of the inherent problems of governing Brazilian cities, the PT has also encountered its own particular set of dilemmas of governance. Problems faced by nascent PT governments have included: inexperience; infighting between party factions; overly optimistic expectations about 
social reform; the need to from coalitions; hostility from local elites and other levels of government; and tension with municipal workers.

\subsubsection{The PT's Inexperience in Municipal Government}

As I have noted, not only PT rank and file, but also their leaders have typically (though not always) come from the ranks of Brazil's politically disenfranchised. While the party's trade unionists and social activists had built up considerable experience organising grassroots movements and mobilising supporters for electoral campaigns, they had considerably less experience in the actual art of governing large cities. This does not mean, as some conservative critics have charged, that the party is inherently unfit for governing but it has lead to PT governments making errors that have been costly and embarrassing (Baiocchi 2003; Gonçalves Couto 2003; Keck 1992). In other cases PT municipalities displayed their naivety by picking battles that they simply could not win. Such as was the case when the PT municipal government in Porto Alegre tried to nationalise the city's public transport system and was forced to back down when it became clear that the bus companies were capable of bringing the city to its knees (Abers 2000).

\subsubsection{Divisions between Different Party Factions}

The PT has also struggled with managing divisions within its own party. This, in part, reflected the PT's initial inexperience at governing, but it was also a reflection of the diverse range of ideological groups that coexisted together under the PT flag. In particular, tensions existed between the radical (leftist) wings of the PT and the party's more pragmatic centralist factions. In power this factionality affected the PT in two ways. Firstly there were the simple ideological disputes about how PT mayors should manage the cities they presided over. Should they attempt to govern 'by the workers for the workers' as more radical groups suggested or should they concentrate on competent management of the capitalist city with a particular emphasis on social programmes? Secondly, there were the power struggles that took place between different PT factions for positions in the new municipal administration. In some early PT municipal governments the mayor chose his or her cabinet almost entirely from their own or allied party factions; often this meant that the PT municipal governments excluded the voice of party tendencies that had significant public support and in other cases it led to municipal administrations that were ideologically isolated from the local party hierarchy (Keck 1992; Gonçalves Couto 2003; Baiocchi 2003; Sader \& Silverstein 1991). 


\subsubsection{The Gulf Existing between Expectations of Social Reform and what is Actually Possible}

Regardless of whether moderate or radical factions controlled power, new PT municipal governments almost invariably experienced tension resulting from the gulf that existed between expectations of social reform that were placed upon them and what they were actually able to provide. As the party represented such a significant break with the existing political elites and as it was, in a sense, a party of the social movements, expectations placed on new PT governments were always high. However, in reality, new PT governments usually found themselves inheriting the legacy of previous years' incompetence and corruption - city halls that were either bankrupt or heavily indebted. With no money available to spend on new investments, PT mayors had to first get the city's finances in order before they could consider implementing any new social programmes. And even when they were able to implement new programmes, the scope of these programmes was more modest than many supporters would have liked. Often, PT mayors were not helped in this dilemma by their own supporters and party members who tended to be unwilling to consider the constraints upon municipal power and were reluctant to limit their expectations (Abers 2000; Baiocchi 2003; Gonçalves Couto 2003; Keck 1992; Sader \& Silverstein 1991). While, in some cases, these tensions reflected the ideological differences between party radicals and centralists (with centralists in power being strongly criticised by radical party members) it was not always the case. In Fortaleza, the party's mayor Maria Fontanelle was associated with radical Maoist party factions, while the local party hierarchy was more ideologically moderate. Yet, in power, Fontanelle - constrained by financial reality - was criticised for being insufficiently radical in her reform process (Baiocchi 2003; Sader \& Silverstein 1991).

\subsubsection{The Hostility of Local Elites to the PT}

Another factor that limited the ability of PT municipal governments to undertake programmes of social reform was the fact that the mayor's office, while powerful, was not the only centre of power in Brazilian cities. While their candidates may have been defeated in the mayoral race, local elites were still a significant politico-economic force. Almost inevitably, these elites were hostile to the PT, more so if they thought that PT reforms were running directly counter to their interests. In some cases (such as the public transport dispute in Porto Alegre) economic elites practised direct economic sabotage (and even resorted to physical violence) against municipal governments while in others a more subtle (if only slightly) form of opposition was practised through the distorted reporting of 
a business-sympathetic media (Abers 2000; Baiocchi 2003; Gonçalves Couto 2003; Sader \& Silverstein 1991).

\subsubsection{The Need to Form Political Coalitions}

Further diminishing the political might of PT mayors was the fact that the PT and its political allies rarely, if ever, won majorities in city council elections. While - particularly in the process of determining the budget - city councils have a more limited role in Brazil than they do in some countries, they still fulfil a legislative function, meaning that any mayor unable to obtain more than half of councillors' votes will be limited in their political programme. To gain a council majority the PT has, on occasion, been forced into political coalitions that have compromised its ideological programmes. While at other times PT mayors have resisted political compromise with councils and have had their governing powers limited by the ensuing political conflict (Abers 2000; Gonçalves Couto 2003).

\subsubsection{Hostility from State Governments}

Political opposition to PT municipal governments has not been limited to the city level either. Brazilian municipalities receive a significant proportion of their tax revenue in the form of transfers from state and federal government. In some cases state governments hostile to PT municipal governments existing within their borders have deliberately reduced the amount of tax transfer money available to the PT municipalities in an attempt to stifle PT political initiatives (Guidry \& Petit 2003).

\subsubsection{Tensions with Municipal Workers}

Further adding to the problems that PT governments have experienced has been the fact that municipal employees' unions are a major support base for the PT. This has meant that, when PT administrations have come into power in some Brazilian cities they have been faced by demands for pay rises from workers who, seeing as they assisted the PT into power, have naturally assumed that PT municipal governments will be supportive of their claims. Such demands have proven problematic for PT mayors, as the salaries of municipal workers typically constitute a major proportion of a city government's expenditures, meaning that further increases would severely limit the amount of money available for other social programmes. This dilemma has often been further compounded by the fact that municipal workers, while certainly not economic elites, are far from being Brazilian society's most needy. In many cases, conflicts over municipal workers' pay demands have degenerated into industrial action that has all but paralysed PT 
administrations and contributed to them failing to be elected in subsequent elections. A sad irony given that the PT itself was formed initially by the trade union movement (Abers 2000; Baiocchi 2003; Gonçalves Couto 2003).

\subsection{Failure in São Paulo}

The experience of the first PT government in São Paulo City illustrates just how the aforementioned dilemmas have conspired disastrously for PT mayors. In 1989, the PT candidate, Luiza Erundina, was elected as mayor of São Paulo. The election reflected a stunning success as well as a significant opportunity for the PT; if the PT could prove itself fit to govern São Paulo, one of the world's largest cities, then it would silence, to some degree, critics that claimed that the PT was too inexperienced to be anything other than a party of opposition. For the party itself, the victory was something of a surprise they had been running third in the polls only days before the election - yet they set about the task of reforming São Paulo with vigour (Gonçalves Couto 2003). An all-star cast of PT intellectuals and social activists including Paulo Friere and Paul Singer was drafted into the administration's cabinet, and a program aimed at fostering participatory governance was embarked on (Abers 2000; Baiocchi 2003). However, even before it was sworn into office, the new government was beset by problems. Erundina herself was not the PT hierarchy's preferred choice of mayoral candidate (Erundina was seen as a radical while they had backed a moderate, Plínio de Arruda Sampiao) and the campaign leading up to the primary vote for the party candidate had been particularly bitter and divisive (Gonçalves Couto 2003). So Erundina was estranged right from the start from a significant sector of her local party. This situation was not helped by the fact that she largely overlooked members of the more moderate PT factions when allocating positions in her administration (Gonçalves Couto 2003). These internal divisions continued throughout Erundina's time in office, with the party consistently exerting pressure on the mayor's office to follow its directives. In power, however, the Erundina administration had much more to worry about than the hostility of their own party, as it quickly became apparent that they had inherited a city hall that was on the verge of bankruptcy (Baiocchi 2003). Before the new PT government could do anything it was going to have to rationalise municipal expenditure. Which, in turn, meant postponement of social investment and instituting 'ideologically unacceptable' policies such as raising bus fares (Baiocchi 2003). An already hostile local party hierarchy leapt upon this perceived unwillingness to follow party polices, accusing the government of being "administratively minded" and "not confronting business owners" (Baiocchi 2003, p. 19). Party moderates were now accusing the radicals of being excessively moderate. 
Erundina's problems did not end with hostile party members and a bankrupt city hall either, she also had to deal with the city's political and economic elites who were, almost without exception, openly hostile to the PT and willing to engage in all manner of activities to ensure that the PT only remained in office for one term (Gonçalves Couto 2003; Abers 2000). Private bus companies suspended services to pressure for fare rises while business groups took the government to court to delay the implementation of a progressive property tax regime (Abers 2000). The non PT, federal and state governments also attempted to hinder the municipal administration: constitutionally mandated federal transfers (tax revenues) were delayed because of bureaucratic 'problems'; the federal bank refused to open accounts earmarked for public housing; and public health funding was diverted away from the city (Abers 2000).

At a local political level, the PT was constrained by the fact that it held less than 30 percent of seats in the city council - an obvious handicap when it came to passing legislation. A potential solution to this would have been the forming of political coalitions. However, Erundina, at the outset of her term in office, was strongly opposed to political coalition arguing that it would mean compromise. Compromised soon enough anyhow, she later reflected that this was one of her greatest errors as mayor (Gonçalves Couto 2003).

A final obstacle for the Erundina administration came in the form of the municipal workers' unions. As I have noted above, such unions were traditional allies of the PT yet this did not stop the unions from making wage claims upon a cash-strapped government. When the government resisted, the unions went on strike. The most devastating of these strikes took place in 1992, only months before municipal elections, when city employees including bus drivers - went on strike, effectively paralysing the city for nine days (Baiocchi 2003; Abers 2000).

Despite all of the above-mentioned problems, the Erundina administration was by no means a complete failure; it had rationalised debt payments and cancelled several dubious, costly, large-scale projects initiated by previous administrations, helping the city hall out of its state of financial paralysis. Furthermore, it did spent a substantial amount (significantly more than previous administrations) of the available municipal budget on programmes designed to improve the lives of the city's least well off: five new hospitals were built; the waiting times for ambulance calls were dramatically reduced; the number of students in municipal schools was increased by 20 per cent, while expenditure on 
education was increased fourfold; the city built 40,000 new homes and provided municipal services to 25,000 previously un-serviced favela residents; a shelter for battered women was initiated; and free contraception became available at public clinics (Baiocchi 2003). Yet, strikes and conflict along with biased reporting in local media had fatally damaged public perception of the PT government and they were heavily defeated in the 1992 municipal elections by conservative rivals. Luiza Erundina left the party and little was done to reduce the perception that the PT was only fit for opposition (Abers 2000; Baiocchi 2003; Gonçalves Couto 2003).

\subsection{Conclusion}

Clearly then, municipal governance has been a difficult task for the PT. Yet, despite facing some or all of the problems listed above, not all PT municipal governments have been voted out of office after one term. Indeed some, such as those in Porto Alegre and Belo Horizonte, have gone on to be re-elected several times. The following two chapters of this dissertation examine the PT governments in Porto Alegre and Belo Horizonte and, in particular, their programmes of Participatory Democracy. 


\section{Chapter 6 - The Participatory Budget and Porto Alegre}

\subsection{Introduction}

The previous chapters of this dissertation have provided a background discussion of the theoretical and practical contexts that the participatory budgets of Porto Alegre and Belo Horizonte have taken place in; they have described those things that are common to both experiences. This chapter now moves away from the background, and into the results of my research by narrowing the focus to Porto Alegre and the participatory budget there. The chapter first provides a description of Porto Alegre along with a brief summary of its history; it then moves on to detail the experiences of the PT in Porto Alegre. After this, the chapter explains how the participatory budget works in Porto Alegre outlining its successes, the problems it has encountered, and the limitations of the process.

\subsection{Porto Alegre}

Porto Alegre (the name translated literally means Happy Port) is the capital of Brazil's southern most state, Rio Grande do Sul. The city is located on the banks of the Rio Guaíba, a large river/lake that is navigable from the city to the sea. The navigability of the Rio Guaíba has allowed Porto Alegre to become one of Brazil's most significant trading ports as well as the financial and commercial centre of Rio Grande do Sul.

\section{Figure 6.1 - Porto Alegre Located on a Map of Brazil}

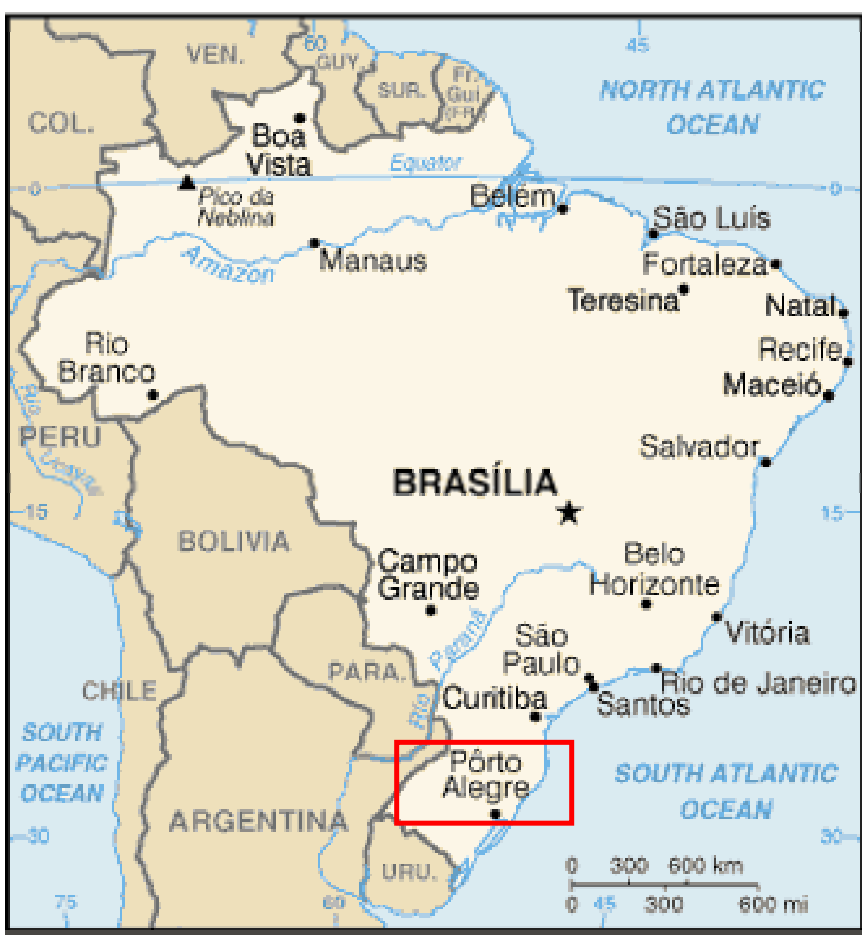

Source: Central Intelligence Agency 2004 
As of the year 2000, the municipality of Porto Alegre had a population of $1,320,739$. The municipality is the centre of the Greater Metropolitan Area of Porto Alegre, which includes satellite cities such as Gravataí and Alvorada and has a population of 3,419,772 (UNDP Brazil 2000). In 1991, Porto Alegre had a Human Development Index (HDI) of 0.824; in 2000 its HDI had risen to 0.865 (UNDP Brazil 2000). 96.5 percent of the city's population were deemed to be literate in the year 2000. Porto Alegre's HDI is the highest for any Brazilian city. Table 6.1 (below) shows the comparative HDIs for all Brazilian Municipalities with populations of greater than 1,000,000 people.

Table 6.1 - Human Development Indices for Brazilian Cities with Populations Greater than 1,000,000

\begin{tabular}{|l|c|c|}
\hline \multicolumn{1}{|c|}{ City } & HDI 1991 & HDI 2000 \\
\hline Porto Alegre & 0.824 & 0.865 \\
\hline Curitiba & 0.799 & 0.856 \\
\hline Brasília & 0.799 & 0.844 \\
\hline Rio de Janeiro & 0.798 & 0.842 \\
\hline São Paulo & 0.805 & 0.841 \\
\hline Belo Horizonte & 0.791 & 0.839 \\
\hline Goiânia & 0.778 & 0.832 \\
\hline Belém & 0.767 & 0.806 \\
\hline Salvador & 0.751 & 0.805 \\
\hline Guarulhos & 0.762 & 0.798 \\
\hline Recife & 0.74 & 0.797 \\
\hline Fortaleza & 0.717 & 0.786 \\
\hline Manaus & 0.745 & 0.774 \\
\hline
\end{tabular}

Source: UNDP Brazil 2000

Per-capita income in Porto Alegre was 710 Purchasing Power Parity Units ${ }^{10}$ (PPPU) in 2000 and the city's Gini Coefficient was $0.61^{11}$. This makes Porto Alegre one of Brazil's more wealthy, egalitarian cities (see Tables 6.2 and 6.3) (UNDP Brazil 2000).

\footnotetext{
${ }^{10}$ The UNDP Brazil (who produce the only comprehensive income data for Brazilian cities) supplies its income figures in a Purchasing Power Parity currency which compensates for the hyper-inflation that Brazil has suffered from and, thus, allows different years' data to be meaningfully compared. Unfortunately, it is not easy to convert this unit of currency into US dollars, so it is does not have much use for international comparisons. It does enable an accurate comparison of Brazilian cities' relative wealth though. In 2000 the per capita income of Porto Alegre was \$2,236 US.

${ }^{11}$ For an explanation of how Gini Coefficients are calculated and their significance see Footnote 6, in Chapter 4.
} 
Table 6.2 - Per-capita Income of Brazilian Cities with Populations of more than $1,000,000$

\begin{tabular}{|l|c|c|}
\hline \multicolumn{1}{|c|}{ City } & $\begin{array}{c}\text { Per-capita Income } \\
\text { 1991 (PPPU) }\end{array}$ & $\begin{array}{c}\text { Per-capita Income } \\
\text { 2000 (PPPU) }\end{array}$ \\
\hline Porto Alegre & 525 & 710 \\
\hline Curitiba & 451 & 620 \\
\hline São Paulo & 536 & 610 \\
\hline Brasília & 472 & 605 \\
\hline Rio de Janeiro & 455 & 597 \\
\hline Belo Horizonte & 415 & 557 \\
\hline Goiânia & 359 & 508 \\
\hline Recife & 303 & 392 \\
\hline Guarulhos & 322 & 344 \\
\hline Salvador & 289 & 341 \\
\hline Belém & 271 & 314 \\
\hline Fortaleza & 236 & 307 \\
\hline Manaus & 277 & 262 \\
\hline
\end{tabular}

Source: UNDP Brazil 2000

Table 6.3 - Gini Coefficient of Brazilian Cities with Populations of more than $1,000,000$

\begin{tabular}{|l|c|c|}
\hline \multicolumn{1}{|c|}{ City } & Gini Index 1991 & Gini Index 2000 \\
\hline Guarulhos & 0.49 & 0.55 \\
\hline Curitiba & 0.55 & 0.59 \\
\hline Goiânia & 0.57 & 0.61 \\
\hline Porto Alegre & 0.57 & 0.61 \\
\hline Belo Horizonte & 0.61 & 0.62 \\
\hline Rio de Janeiro & 0.61 & 0.62 \\
\hline São Paulo & 0.56 & 0.62 \\
\hline Brasília & 0.61 & 0.64 \\
\hline Manaus & 0.57 & 0.64 \\
\hline Belém & 0.6 & 0.65 \\
\hline Fortaleza & 0.65 & 0.66 \\
\hline Salvador & 0.65 & 0.66 \\
\hline Recife & 0.67 & 0.68 \\
\hline
\end{tabular}

Source: UNDP Brazil 2000 
While Porto Alegre is one of the wealthier, more egalitarian cities in Brazil, it has not escaped the poverty or social problems that affect the rest of the country: as much as a third of the population live in inadequate housing and a 1997 study estimated that the city contained 250 separate favelas (Abers 2000).

\subsection{The History of Porto Alegre}

Porto Alegre was originally a small village populated by settlers from the Azores who were paid to settle there by the Portuguese Government as part of its plan to keep the south of Brazil out of Spanish hands (Costa \& Velho Cardone n.d.). Porto Alegre became the state capital of Rio Grande do Sul in 1807 and further immigration to the town continued throughout the $1800 \mathrm{~s}$ - from the 1820 s onwards a significant number of these immigrants came from Germany and Italy as well as Portugal (Encyclopædia Britannica 2004b). During the Farroupilha rebellion of 1835 to 1845 the city was captured by the rebels (who were fighting for the state of Rio Grande do Sul to become an independent republic) and recaptured by loyalist (pro-Brazil) forces (Costa \& Velho Cardone n.d.).

Despite the fact that the Farroupilha rebellion was crushed, Porto Alegre (and Rio Grande do Sul in general) remained a centre of political involvement. Rio Grande do Sul was home to Getúlio Vargas the populist president (and dictator), and Porto Alegre was the base for left leaning politicians Leonel Brizola and João Goulart. In addition to this, some of the European immigrants who arrived in Porto Alegre in the $19^{\text {th }}$ and early $20^{\text {th }}$ centuries were anarchists and socialists fleeing political persecution in Europe; their continued activism upon arrival in Porto Alegre helped shape the city's political character (Abers 2000; Goldfrank 2003). From the 1950s until the 1980s immigration (now primarily from other parts of Brazil) caused Porto Alegre to grow at a phenomenal rate. The result of this was a haphazard expansion of the city, many areas were settled illegally (without legal title to the land) and most of the new settlements (practically all of the lower socio-economic ones) ended up receiving few or no municipal services (Do Canto 2003).

When the presidency of João Goulart was toppled by a military coup in 1964, Porto Alegre became a centre of resistance to the military dictatorship that followed (Goldfrank 2003). During this period of resistance, many of Porto Alegre's neighbourhood associations began to change their nature. Prior to the military dictatorship, Porto Alegrean neighbourhood organisations typically operated in a clientelistic manner offering their support to various politicians in return for public works in their 
neighbourhood. While for the first few years of military rule this co-opted relationship continued, the later part of the dictatorship saw a change in the relationship between neighbourhood organisations and the regime, as many (though not all) Porto Alegrean neighbourhood organisations took on a confrontational stance (as much as was possible) to the dictatorship and began to support opposition parties (Abers 2000).

In 1984, Porto Alegre held its first democratic mayoral elections since 1964. In these elections Aleceu Collares of the populist/centre-left Partido Democrático Trabalhista (Democratic Labour Party, hereafter PDT) was elected mayor and entered into consultation with neighbourhood groups and other activists (who were generally supportive of him) about how city revenues could be spent. Collares, however, proved to be a major disappointment to neighbourhood and social groups as he paid little or no attention to their demands and set about governing the city in a corrupt inefficient manner (Abers 2000).

In general, the 1980s were something of a 'lost decade' for Porto Alegre; the city was the only metropolitan region in Brazil other than Rio de Janeiro where the proportion of the population living in poverty actually increased in the 1980s. The proportion of Porto Alegreans living in sub-standard housing increased from 15 percent of the population in 1980 to 28 percent in 1989 (Abers 2000, p. 37).

In 1989 Porto Alegre elected PT candidate Olivio Dutra to be its mayor.

\subsection{The PT in Porto Alegre}

On assuming power in Porto Alegre the PT had to face many of the problems that I described in Chapter 5 as being typical dilemmas experienced by the party in its governance of Brazilian municipalities. It inherited a city hall that was in a state of disarray: basic reporting procedures were not in place; city workers and suppliers had not been paid for two months; and payment on a major loan was due at the end of the month (Abers 2000; Branford \& Kucinski 2003; Goldfrank 2003; Wainwright 2003). João Verle (the city's current mayor who was then Financial Secretary) described his first day in the city hall as "awful" (Goldfrank 2003, p. 29). Compounding the city hall's problems was the fact that, after he had lost the election to the PT, but before the transfer of power, Collares had granted municipal workers a significant wage rise meaning that " 95 percent of the city's budget was now going towards paying municipal workers" (Márcia da Silva Quadrado, Co-ordinator of Strategic Planning at GAPLAN, the department that co- 
ordinates the participatory budget, interview notes). In effect the city hall was on the edge of bankruptcy and had almost no money available to spend on new investments (Navarro 1998). Moreover, in part because it knew that it relied on municipal workers as a source of support, and in part because it wanted to avoid a costly confrontation at the beginning of its term in power, the new PT city government felt that it could not rescind the pay increase granted to the workers (Abers 2000).

In addition to the above external problems, the new PT administration suffered from internal strife as well, with more radical party factions displaying open hostility to the moderate factions who had most of the power in the new government (Abers 2000; Goldfrank 2003). The mayor's office then made the mistake of trying to nationalise some of the local bus companies during a dispute over fare increases - the result of this was open economic sabotage by bus companies and the city's public transport system being brought to its knees (Abers 2000; Goldfrank 2003).

All of these problems along with the initial failures of the participatory budget in Porto Alegre (these failures are discussed below), meant that in 1990, 40 percent of people polled in a survey rated the PT government as "bad or terrible" (Goldfrank 2003, p. 36). By 1991 it looked like the PT in Porto Alegre was going to suffer a similar fate to many of the other PT administrations that came to power in 1988: the failure to be re-elected for a second term. However, in Porto Alegre the PT was able to stage what was later referred to as "a grande virada (the great turnaround)" (Abers 2000, p. 75), the result of which has been re-election of PT candidates to the mayor's office three consecutive times (De Sousa Santos 1998). In a public opinion survey in 1996, the PT's performance was rated as good or excellent by 65 percent of the population and better than average by 85 percent of people polled (De Sousa Santos 1998).

The first, and perhaps most significant, component of the 'great turnaround' were the actions that the mayor's office took to increase city revenues. In this the mayor's office was helped to some degree by the decentralisation of the 1988 Brazilian constitution which increased the city's revenues by 22 percent. Even so, the city hall was still effectively insolvent; however, the new constitution made their financial situation less dire than it would have otherwise been (Abers 2000, p. 76). In 1989 the mayor's office passed legislation that made the city's property taxation regime more progressive; an already existing service tax was lowered on essential services but raised on all other services; and all taxation was indexed, monthly, to inflation. In addition to this, the municipal government became far more diligent in pursuing taxes owed to them (Navarro 1998). 
The effects of these changes were dramatic and by 1990 municipal tax revenues were already 40 percent higher than they had been in 1989 (Abers 2000, p. 76).

At the same time that the PT municipal government acted to increase the revenue it had available it also restructured the way the city hall itself was run - old bureaucratic departments were bypassed and a new centralised planning body was set up meaning that the money that the city had was being spent more efficiently (Goldfrank 2003).

A third factor that contributed to the PT government's turnaround in fortunes was the participatory budget itself. Once money started to become available for investments, the participatory process meant that people could - often for the first time in Porto Alegre's history - obtain municipal works in their neighbourhood. This in turn was an excellent 'advertisement' for the PT and improved the party's image, particularly in poorer, less well serviced neighbourhoods (Abers 2000). This and other successes of the participatory budget in Porto Alegre are discussed in more depth below.

\subsection{The Participatory Budget - How it Functions}

The participatory budget in Porto Alegre has slowly evolved throughout its existence; as an entity it is similar but not identical to the process that was introduced in 1989. An explanation of how the participatory budget has changed over time in Porto Alegre is covered later in this chapter; this current subchapter limits itself to discussing how the participatory budget operates at present. Unless otherwise stated, the description of how the participatory budget functions is based on the work of Abers (2000), Avritzer (2002b), De Sousa Santos (1998), Menegat (2002), Prefeitura de Porto Alegre (2004), and Prefeitura de Porto Alegre (2004b).

\subsubsection{What is actually decided?}

Up for decision in the participatory budget is the city's annual budget for new investments. In 2004 the new investment budget was $\mathrm{R} \$ 99,268,863^{12}$ - this was 13 percent of the overall municipal budget (Prefeitura de Porto Alegre 2004, p. 11). Participants' representatives can also vote on some of the rules of the actual running of the participatory budget.

\footnotetext{
${ }^{12}$ On the $6^{\text {th }}$ of August $2004 \mathrm{R} \$ 99,268,863$ was worth $\$ 32,350,941$ USD.
} 


\subsubsection{A Parallel Democratic Process}

It is important to note that the participatory budget has not replaced traditional representative democracy in Porto Alegre. Every four years the city still votes for the mayor and the city councillors. The participatory budget sits parallel to this existing democratic process. The participatory budgeting process is co-ordinated by the mayor's office and the budget itself has to be ratified by the city council (a potentially problematic issue as will be discussed later).

\subsubsection{Government Co-ordination Bodies}

Overseeing the entire participatory budgeting process are two separate government departments the Gabinete de Planejamento (Planning Cabinet in English, hereafter referred to by its Portuguese acronym GAPLAN) and the Gabinete de Relacoes com as Comunitarias (Community Relations Cabinet in English, hereafter GRC). GAPLAN coordinates the overall participatory budgeting process and liases between the participants' representatives and the council departments. In particular, GAPLAN is responsible for working with participants to turn their demands into a technically and economically feasible budget. The GRC, on the other hand, co-ordinates the popular participation in the process, arranging and co-ordinating meeting and educating participants (De Sousa Santos 1998; Luis Alberto Giradi - Associate Co-ordinator of the GRC, interview notes).

\subsubsection{Regional and Thematic Processes}

The participatory budget in Porto Alegre is, in essence, two processes that run alongside each other, meeting in the preparation of the final city budget. The first process is based around geographical regions (sub-regions of Porto Alegre) and the second is based around different 'themes' that are considered on a city-wide basis. In the regional component of the participatory budget, the city is broken up into 16 different administrative regions. Residents of these regions participate in prioritising what types of investments they want in their region as well as suggesting specific projects. In the thematic process, residents of the city meet to contribute to the decision of city-wide spending priorities in six different 'thematic' areas: transportation; culture; economic development and taxation; education, sport and leisure; urban development and environment; and health and social assistance.

Both the regional and thematic processes contain three separate components: direct assembly style democracy; representative democracy; and negotiation with the city hall. How each of these components interact, along with their role in the budget process is described in more detail below; however, to enable the reader to begin to formulate a 
conceptual overview, Figure 6.2 illustrates the interaction between the three components of the two processes.

\section{Figure 6.2 - Conceptual Overview of the Participatory Budget in Porto Alegre}

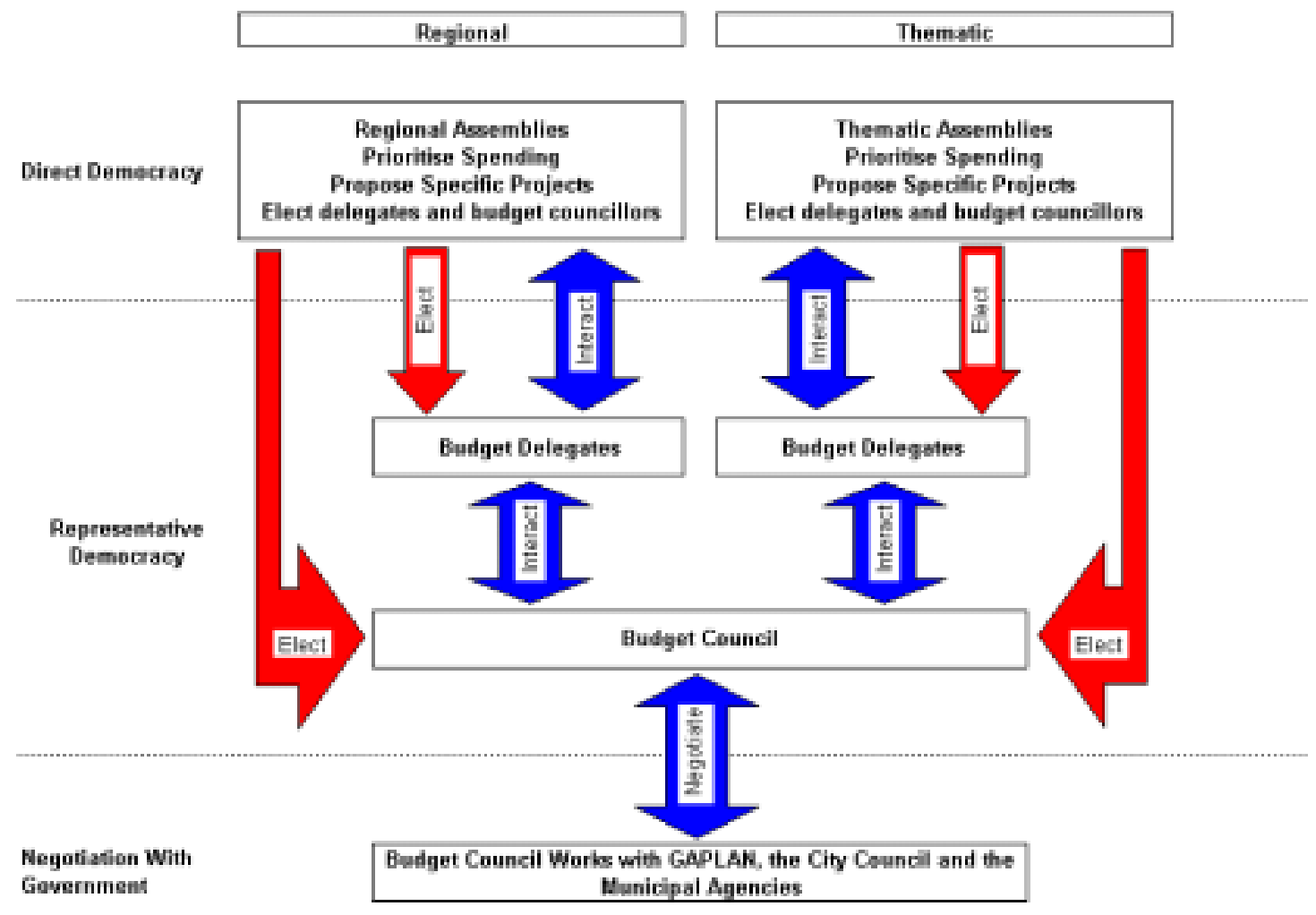

Source: Abers 2000 and my own fieldwork

\subsubsection{The Regional Assemblies and Budget Delegates}

The regional process starts every year in March and early April when community groups begin meeting. Within these community meetings participants discuss their demands (projects that they desire) as well as plan methods of mobilising the communities they live in. Also, representatives of the city hall account for how the previous year's budget was spent, participants provide feedback on this and the city explains the parameters of the budget to be discussed for the year. Typically these preliminary meetings take place on a sub-regional (neighbourhood) level.

In April and May the regional assemblies are held. The regional assemblies are where participants vote to select the Budget Councillors from their region who will represent the region on the Budget Council ${ }^{13}$ (each region gets two Budget Councillors on the Budget

\footnotetext{
${ }^{13}$ The Budget Council is part of the participatory budgeting process and should not be confused with the city council.
} 
Council). The number of participants who take part in these assemblies determines the number of delegates that a region can send to the budget delegate forums. A larger turnout allows for more delegates to be selected, however, as the number of participants increases, the number of additional delegates eligible to be selected reduces.

In May and July an additional series of regional meetings is held. Once again, these meetings are open to all registered residents of a region; the meetings may be held on a regional level, however, in more organised regions they are held at a sub-regional (neighbourhood) level. In these meetings the delegates to the budget delegate forums are elected, specific projects for the region are discussed and participants vote to establish a hierarchy of broad spending priorities for their region. In this vote on spending priorities, participants rank the following spending categories in order of importance: sanitation, housing, roading (particularly road sealing), education, social assistance, health, transportation, leisure areas, economic development, culture, and environment.

After the votes have been taken, the regions' delegates visit proposed projects and familiarise themselves with them. They then deliberate on the proposed projects at the regional delegate forums. Once the regional delegate forums are complete, and the projects decided upon, the delegates present their region's proposals and spending hierarchies to the Budget Council. After this 'presentation', the delegates have a continuing role in the participatory budgeting process, liasing with both the Budget Council and their communities, thus becoming a link between participants and the Budget Council. How much each region will ultimately have to spend on each of the spending categories is based on a weighting system that takes into account the priority the participants rated the category, the region's population, and how well the region is already provided for in that category of investment.

Once the budget has been finalised, the delegates supervise the implementation of the projects that were proposed for their region.

\subsubsection{The Thematic Assemblies and Budget Delegates}

The thematic process generally mirrors the regional one. In March and early April, groups interested in the thematic process start meeting, discussing priorities and mobilisations.

In April and May thematic assemblies are held; there are 5 of these, one for each citywide theme (transportation; culture; economic development and taxation; education, sport 
and leisure; urban development and environment; and health and social assistance). Participation in the thematic assemblies is open to all residents of Porto Alegre. As in the regional assemblies, participants in each thematic assembly vote for their representatives on the Budget Council (two representatives are selected for each theme). The number of participants who participate in these thematic assemblies determines the number of delegates that can represent each theme in the thematic budget forums. As with the regional assemblies, a larger turnout means more delegates, however, as the number of participants increases, the number of additional delegates eligible to be selected gets less. In these first round thematic assemblies participants also vote to establish a hierarchy of spending priorities for the theme (this differs from the regional assemblies).

In May and July a second series of thematic meetings is held. In these meetings the thematic budget delegates are elected.

As in the regional process, thematic delegates liase with Budget Council members and other participants and supervise the implementation of the projects.

\subsubsection{Bringing it all together at the Budget Council}

The 32 regional Budget Councillors, along with the 10 thematic Budget Councillors are joined by one representative of the Porto Alegre Municipal Workers Union, one member from the Union of Porto Alegre Residents Associations and two representatives from the municipal government (who do not have the right to vote). The Budget Council now works with GAPLAN and the different municipal departments to turn the participants' demands into a workable investment plan. In particular, demands that are technically unfeasible may be removed at this phase. Once a coherent budget plan is drawn up, the budget is presented to the city council for ratification. In theory, the city council could actually turn down the participatory budget at this stage, however, in practice they never do so as councillors are unwilling to vote against what they see as the public voice. The Budget Council also has the power to change some of the overall parameters of the participatory budgeting system.

\subsection{The Participatory Budget as an Evolutionary Process}

Since the participatory budget's inception in Porto Alegre in 1989, there have been several significant changes made to the budgeting process. The changes along with the rationale for them are listed below: 
- In 1989 the prototype participatory budget was run with the city split into only five districts. The result of this was that, "[1]eaders of the community movement complained that the five-part division of the city created districts too large to allow for adequate participation or representation" (Goldfrank 2003, p. 12) . As a result of this, before the 1990 participatory budget-round, the city was re-divided into 16 districts (Goldfrank 2003).

- In 1990 the PT administration prevailed upon the Budget Council to agree to a plan in which 65 percent of the money available for investment through the participatory budget would be spent on the city's five poorest districts. This was the system used for the 1990 participatory budget, however, in 1991 the representatives of the 11 other districts on the Budget Council pressured (successfully) for this bias to be removed from the budget. In addition to this, a weighting system that provided more money to districts where participation was higher was also removed. These criteria were replaced by the current system of distribution that allocates money between the districts through a calculation based upon a district's population, need for investments and the priority put on each type of investment by participants (Abers 2000; Goldfrank 2003).

- Up until 1993 the participatory budgeting process in Porto Alegre was only run at a regional level, however, in 1993 the municipal government introduced the city-wide thematic process described in Sub-Chapter 6.5. Accompanying this change was an effort to steer the participatory budget away from focusing exclusively on small intradistrict projects and towards a broadening of perspective that took into account the city as a whole. According to most commentators on the history of the participatory budget, the main factor motivating this change was the replacement of PT mayor Oliver Dutra in 1993 by Tarso Genro. Under Brazilian law city mayors can only serve one term in office, this meant that the PT was obliged to run a candidate other than Dutra in the elections. Tarso Genro - Dutra's former vice mayor - won the 1993 elections comfortably for the PT. While Dutra's background was that of a radical union leader, Genro was a middle class lawyer and political philosopher who, in general, appeared inclined to try to steer the process away from being aimed purely at serving local needs. Genro hoped to foster an overall spirit of city-wide citizenship that encouraged people to think beyond their own neighbourhood. Genro was also keen to foster more middle class involvement in the participatory budget (participants in the participatory budget primarily come from lower socio-economic groups). The 
attempt to cultivate some emphasis on city-wide processes was also probably a response to criticism from some of the participatory budget's opponents that the process ignored the development of Porto Alegre as a whole (Abers 2000; Goldfrank 2003; Wainwright 2003).

- During Genro's term as mayor the municipality also provided much more technical feedback on proposed projects - going so far as to reject projects that they thought technically un-viable. This change (which has continued to the present day) came about as a result of the fact that, in previous years, "some investment proposals accepted by the administration had gone awry, turning out to be economically unsound or having negative economic impacts on the regions where they were implemented" (Abers 2000, p. 87).

- Up until the end of the 1990s the participatory budget had an additional round of assemblies. This round has recently been removed, presumably in order to streamline the budgeting process, make it less complicated and diminish the time demands on participants (Branford \& Kucinski 2003).

- As the participatory budgeting process has been developed, additional participatory processes have been set up in Porto Alegre: every few years a conference of the city is held to debate future directions for the city; participatory processes have been developed in the formulation of some areas of government policy; and in 2003/04 a participatory budget was set up within city council departments enabling workers to have a say in the departments' internal budgets (De Sousa Santos 1998; Márcia da Silva Quadrado, interview notes).

\subsection{A Note on the Outcomes of the Participatory Budget in Porto Alegre}

So far in this chapter I have described Porto Alegre, the history of the PT in Porto Alegre and the way that the participatory budget works in Porto Alegre; the chapter now moves on to detail the outcomes of participatory budgeting in the city. The outcomes are grouped under three headings: successes; problems and limitations; and uncertainties. 


\subsection{Successes of Participatory Budgeting in Porto Alegre \\ 6.8.1 Provision of Municipal Services to the Previously Excluded}

The one area where almost all of my interviewees were in agreement was that the participatory budget in Porto Alegre had been incredibly successful in facilitating the increased provision of municipal services, particularly to sectors of society that previously had not received them.

Marcelo Kunrath Silva, an academic at the Federal University of Rio Grande do Sul, who has researched the participatory budget both in Porto Alegre and also where it has been introduced to neighbouring cities, stated in his interview that:

There has been an incredible, a noticeable improvement in the quality of life in the city. For a slice of the population (which did not have them before) basic services have improved. And for other groups (the middle class) cultural events etc. have become more accessible.

Luis Alberto Giradi, the head of the GRC noted that:

Many areas had been waiting 30 or 40 years to get the basic services they had asked for. Through the participatory budget they received these services.

And, Márcia da Silva Quadrado, the Co-ordinator of Strategic Planning at GAPLAN commented:

Previous governments undertook municipal works in the city centre and in zones of high income or middle class neighbourhoods - and there were no works in the peripheral, lower income areas. Through the participatory budget this has changed.

The only apparent voice of interviewee dissent on this matter was the conservative city councillor who, among other negative comments about the participatory budget, claimed that "...the participatory budget is a fantasy to bring good political results for the PT." 
A review of all the available empirical data on the topic seems to confirm the positive, rather than the negative assessment of the provision of municipal services resulting from the participatory budget. For example:

- Between 1988 and 2002 the city hall paved 300km of roads in Porto Alegre, reducing by 43 percent the amount of road in need of paving in the city (Prefeitura de Porto Alegre 2004c, p. 9);

- The city hall increased, from 94.7 percent to 99.5 percent, the percentage of the city receiving treated drinking water (Prefeitura de Porto Alegre 2004c, p. 11);

- The city hall increased the percentage of the city served by sewerage drains from 46 percent in 1989 to 84 percent in 2002 (Prefeitura de Porto Alegre 2004c, p. 11);

- The amount of sewage treated was increased from two percent in 1989 to 27 percent in 2003 (Prefeitura de Porto Alegre 2004c, p. 11);

- Investment in housing projects increased 335 percent between 1989 and 2000 (Menegat 2002, p. 195);

As new investments, all (or almost all) of the above improvements came about via the participatory budgeting process. It does not appear that these improvements were merely extensions of pre-existing trends either. In the case of sewage and drainage, the city hall was able to lay 900 kilometres of drains between 1989 and 1996, this compares to the 1100 kilometres of drainage laid down by all of the previous municipal administrations combined (De Sousa Santos 1998, p. 478).

In addition to the above increases in service provision, the city hall now operates:

- 164 community health centres, compared to 13 in 1988 (Prefeitura de Porto Alegre 2004c, p. 15);

- 92 primary schools compared to 29 in 1988 (Prefeitura de Porto Alegre 2004c, p. 16).

It is worth noting that the 1988 constitution transferred many health and primary schooling responsibilities from federal and state governments to municipal governments, so it is reasonable to expect that these numbers would have increased regardless of the participatory budget. However, in addition to increasing the number of schools and medical centres, the city hall has also increased the number of community crèches in Porto Alegre from zero in 1988 to 129 in 2003 (Prefeitura de Porto Alegre 2004c, p. 17). While the participatory budget's role in the increase of medical centres and primary 
schools is somewhat unclear, these community crèches have been a direct result of the process.

It is possible to argue that the PT, with its municipal tax reform and commitment to redistribution in Porto Alegre, would have made these improvements anyway, without the aid of the participatory budget. This is a difficult question to test simply because there have not been any PT municipal governments, which have stayed in power long enough for their performance to be assessed alongside Porto Alegre, that have not used participatory budgeting. This limitation itself raises an interesting question: what role does the participatory budget play in keeping the PT in municipal power? I will explore this question later in this sub-chapter and also in Chapter 8.

Without any ability to test the participatory budget's effect on the provision of municipal services in Porto Alegre against a 'control' city, it is important then to limit any assessment of the material results of the budgeting process to the following statement.

In Porto Alegre the participatory budget contributed to the increased provision of municipal services to sectors of society that had previously been denied these services. Participatory budgeting may not have been the only means that this re-distribution could have been effected, however, it did provide a successful medium for the re-distribution to take place through.

While the participatory budget may not have been the only way to achieve the better provision of municipal services in Porto Alegre, the budget has, however, had other effects that are inherently linked to its means of operation.

\subsubsection{Opening a Space for the Political Participation of the Previously Excluded}

One success claimed by some proponents of the participatory budget has been the steady increase in the number of participants that has occurred since the budget process recovered from its first troubled years. Figure 6.3 below tracks participation levels in Porto Alegre from 1990 - 2000. 
Figure 6.3 - Participation in Regional and Thematic Assemblies, Porto Alegre

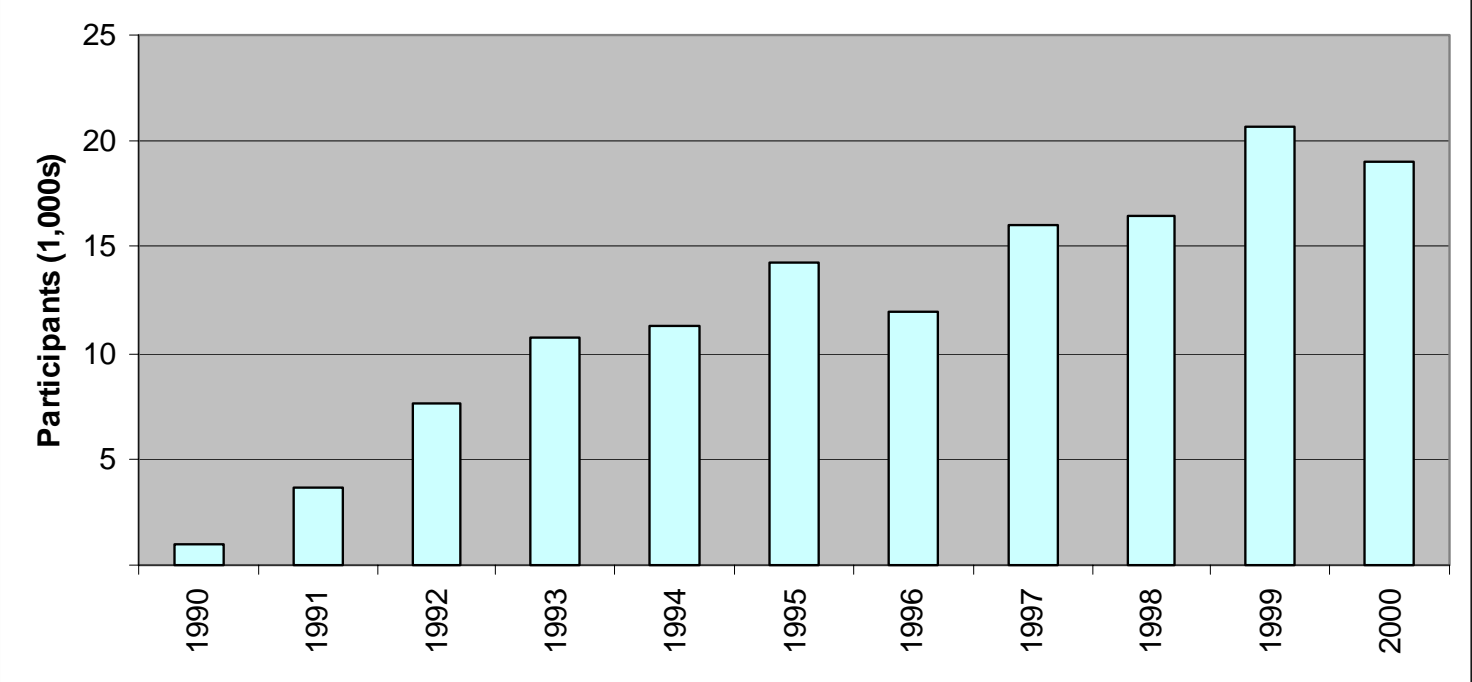

Source: Menegat 2002, p. 196

Looking at Figure 6.2 it is clear that participation in the participatory budgeting process did increase dramatically throughout the 1990s, however, two points are worth noting when considering this. Firstly, the increase in participation starts to taper off in 2000. While I do not have any hard data on participation for 2001, 2002 and 2003 the impression I got from interviews was that participation had remained relatively constant across those years. This would appear to indicate that participation may have reached its maximum levels in the city. The second point is that, while in absolute terms, the number of participants may seem quite high, it only constitutes approximately 1.5 percent of Porto Alegre's overall population. Even if informal consultations and neighbourhood meetings are taken into account, the process still only involves (and this is probably a generous estimate) approximately eight percent of the city's population (Shah \& Wagle 2003), a significantly lower percentage than participate in city elections.

However, while the overall level of participation may not be as high as elections, the important point, as many observers of the process have noted, is that the participatory budget has opened up a space for non-elites to participate in the running of the city (Baiocchi 2003; Wainwright 2003). As Luis Alberto Giradi noted in his interview with me, "the previously excluded now have a voice."

Empirical data back up this claim. Table 6.4 shows the break down by socio-economic class of participants, delegates and Budget Councillors in the 2002 participatory budget. 


\section{Table 6.4 - Economic Status of Participants in Porto Alegre's} Participatory Budget (2002)

\begin{tabular}{|c|c|c|c|}
\hline $\begin{array}{c}\text { Number of Minimum } \\
\text { Salaries Earned }\end{array}$ & $\begin{array}{c}\text { Meeting } \\
\text { Participants }\end{array}$ & Delegates & $\begin{array}{c}\text { Budget } \\
\text { Councillors }\end{array}$ \\
\hline $\mathbf{0 - 2}$ & $39.4 \%$ & $23.7 \%$ & $21.7 \%$ \\
\hline $\mathbf{2 - 4}$ & $29.9 \%$ & $31.8 \%$ & $28.3 \%$ \\
\hline $\mathbf{4 - 8}$ & $18.4 \%$ & $25.3 \%$ & $21.7 \%$ \\
\hline $\mathbf{8 - 1 2}$ & $5.1 \%$ & $9.0 \%$ & $13.3 \%$ \\
\hline $\mathbf{1 2}+$ & $6.8 \%$ & $10.2 \%$ & $15.0 \%$ \\
\hline No Reply & $0.4 \%$ & $0.0 \%$ & $0.0 \%$ \\
\hline
\end{tabular}

Source: Baierle 2002, p.24

While their numbers do diminish somewhat at the Delegate and Budget Councillor levels, the poorest two categories in the survey clearly dominate participation in the participatory budgeting process. This is a significant change given, as outlined in background chapters, the typical elite domination of Brazilian politics. ${ }^{14}$

The only interviewee who disputed the claim that the participatory budget had opened up new spaces for political participation in Porto Alegre was the conservative councillor. $\mathrm{He}$ claimed the complete opposite: that participatory budgeting had made Porto Alegre society less participatory. He stated that:

When I was in government [he was a senior figure in an earlier city government; I have edited out his title to protect his anonymity] I would have people waiting outside my door every morning to see me. A line of them. And I would give each one, one minute to make their claim. This does not happen any more.

What he is describing sounds suspiciously like clientelism, however, even if we give him the benefit of the doubt and assume that this one minute system represented genuine participation, it would be very difficult for the councillor to facilitate the same levels of participation that occur at present. For example, if he were to listen to the demands of the approximately 20,000 people who participate in the participatory budget each year, and if

\footnotetext{
${ }^{14}$ Baierle (2002) also reports on the gender breakdown of participants, showing that, in 2002, at the participant and delegate level, women outnumber men in the participatory budgeting process. Only at the Budget Council level are men more prevalent.
} 
he were to give them each only one minute, and if he were to work non-stop at this for 8 hours a day, it would take him 42 days to hear everyone's demands.

\subsubsection{Reduced Clientelism}

Another success of the participatory budget that many interviewees observed, and which has also been noted in much of the literature on Porto Alegre, (see for example Abers 2000; Avritzer 2000; De Sousa Santos 1998; Goldfrank 2003; Wainwright 2003) is the reduction in clientelist politics that the participatory budget has brought about. Prior to the participatory budgeting system, the primary way that people could arrange for municipal works in their neighbourhood was to lobby councillors with the promise of votes in exchange for works (this practice is described in Portuguese as a "troca de favores" - an exchange of favours). By providing an alternative, more transparent, and reliable way for people to obtain municipal works, the participatory budget caused a significant reduction in this culture of political exchange. Marcelo Kunrath Silva (in his interview) explained how the system used to work and how the participatory budget has changed it:

One success of the participatory budget was a change in the relationship between the population and the government - a reduction in the culture of clientelism, in the culture of trocas de favores. In the old system, people could obtain improvements but it was done as part of a political system (troca de favores) not as a right of citizenship. The participatory budget broke the traditional way of getting things done. And made it clear that citizens could expect improvement. In the old system the councillors were the intermediaries between the people and the municipal coffers (which belonged to the people by right). Now the money is with the people.

Avritzer's (2002c, p.1) survey of community groups in Porto Alegre shows that prior to the initiation of the participatory budget process in Porto Alegre, 62.7 percent of community organisations had some access to public goods and 41 percent of the organisations that did have access had obtained this accesses through political mediators. After the introduction of the participatory budget, 89.6 percent of community organisations responded that they had access to public goods, and zero percent replied that the intervention of politicians was now necessary to obtain these goods. 


\subsubsection{Reduced Corruption}

Along with discussing the reduction in clientelism that has occurred in Porto Alegre, much of the literature has also noted that the city's political culture has become less corrupt since the participatory budget was introduced (for examples of this see Navarro 1998; Wainwright 2003; Wampler 2002). While not all interviewees mentioned the reduction of corruption when asked about the participatory budget's successes, none claimed that it had not occurred. João Sucupira, the director of IBASE was typical of those who discussed the reduction of corruption saying that:

A reduction in corruption has accompanied the increase in public participation.

Navarro (1998, p. 78) states that the participatory budget in Porto Alegre brought about an "amazing reduction of corrupt behavior and administrative malpractices [sic] in day-today public affairs" which he adds is "so widespread in the country [Brazil]". He then goes on to explain $(1998$, p. 78$)$ that the participatory budget achieved this by:

$[\mathrm{I}]$ ntroducing an unprecedent [sic] transparency in the formation, allocation and implementation of the municipal budget, [by] "opening" it to the general scrutiny by the citizenry, the administrations of the period dramatically reduced the room for petty and backstage arrangements linking civil servants and private interests. Not to mention major illegal and/or ethically illicit proposals, rendered impossible when all acts and intentions are so loudly publicized.

It is difficult to empirically back up these claims, however, it does seem intuitive that, by opening up every aspect of the municipal investment budget to public scrutiny, and by implementing a system that enables the tracking of projects from the time that they are formally requested to the time when they are completed, the PT, through the participatory budget, will have significantly reduced corruption in Porto Alegre. 


\subsubsection{Public Satisfaction}

Despite the fact that the participatory budget has received considerable negative publicity from Porto Alegre's conservative, mainstream media outlets (this is discussed in more detail in Sub-Chapter 6.9) the process has come to be viewed favourably, not just by the participants but by the public in general in the city. Luis Alberto Giradi, when interviewed stated that:

It's true that only a very small percentage of the total population of Porto Alegre participate in the participatory budget, but they did a survey of opinions about the process across the whole city - 70 percent or 80 percent of the population valued the process and thought it was good. Although there are people who live in wealthy neighbourhoods who have everything they need, they still think that the participatory budget is a good thing - they recognise its ability to work for the general good of the city.

Wainwright (2003, p. 3) confirms Giradi's claims about the participatory budget citing a survey where 85 percent of respondnets expressed favourable opinions about the participatory budgeting process in Porto Alegre.

While it is probably true that popularity is not strictly a 'success' of the participatory budgeting - more correctly it is a measure of its other successes - it not unreasonable for the PT themselves to view the popularity of the process in a positive light. The participatory budget is their flagship programme in the city, and if people are inclined to view it favourably, then presumably they will be more inclined to vote for the PT. This point brings me to the final 'success' that can be attributed to the participatory budget in Porto Alegre: the continued re-election of the PT.

\subsubsection{Keeping the PT in Power}

As I mentioned earlier in this chapter it is possible to argue that the PT - who through their actions in Porto Alegre have shown the traits of a genuinely reformist government could have brought about the improvements in the provision of municipal services without needing to operate via the participatory budget. Even if we are to accept this possibility, it is important to note that the participatory budget would still have to be considered important, simply for the role that it has played in keeping the PT in power in the city. Márcia da Silva Quadrado stated as much in her interview with me: 
The second success is that, thanks to the participatory budget, the PT has been re-elected three times. This is because the participatory budget is presenting concrete results in the city.

This electoral success is very significant because, as I described comprehensively in Chapter 5, PT municipal governments have had a disastrous habit of being voted out of office after only one term. The main exception to this being in cities where they have successfully implemented the participatory budget.

Electoral success is also a very important by-product of the participatory budget for another reason: when the PT has been voted out of power from state or municipal government, the political parties that have replaced them have (with only one exception in Belo Horizonte) dismantled or fatally weakened the participatory processes that the PT has set in place (Nylen 2003). When I interviewed him, Sergio Baierle described the dismantling that took place when the PT lost the governorship of Rio Grande do Sul in 2002:

A new government came in. They did not abandon the process, but they changed it, in its main structures. So they abandoned the programme of direct participation and now it is a process of previously organised forces like the traditional forces... at a state level they just cut it [popular participation] and they have been able to so while claiming that 'we are continuing the process, it just cuts some populist bias.'

So the participatory budget is important in ensuring that the PT stays in power in the municipalities where it operates. This in turn is important because it means that the strong participatory budget process continues to be operated in these cities. Sofia Cavedon, the PT city councillor who I interviewed made this point stating that:

There is an inter-relationship between the participatory budget and the PT. The successes of the participatory budget keep the PT in power and, at the same time, the continued leadership of the PT ensures that the participatory budget keeps operating. 


\subsection{Problems and Limitations}

The following sub-chapter describes three things. Firstly, it details external problems that have hindered the implementation and operation of the participatory budget in Porto Alegre. Then it describes the problems of the participatory budget itself - what has gone wrong internally. Finally, it highlights some of the observed limitations of the participatory budgeting process.

\subsubsection{External Problem - Lack of Money}

One problem that has affected the participatory budget, mentioned by almost all interviewees as well as in much of the literature (see for examples Abers 2000; Goldfrank 2003) has been the limited availability of money to spend on new investments. The dilemma can be explained simply: if the city hall does not have money to spend on new investments then people's demands will go unmet and they will cease to participate in a process that they (rightly) see as providing no rewards for their efforts.

Marcelo Kunrath Silva, in his interview, noted that:

The popularity of the participatory budget is a result of the fact that people can see pragmatic improvements from the participatory budget. For this, however, the process needs money. The initial experience of the participatory budget (when it had no money) was traumatic.

The initial experience that Marcelo talks about was the first round of the participatory budget in Porto Alegre (1989/90) where participants made long lists of demands that the near bankrupt city hall was completely unable to meet. Not surprisingly, in the following year participation in the process fell significantly (Abers 2000; Goldfrank 2003).

Márcia da Silva Quadrado, in her interview described this in more detail:

The last day that the Collares administration was in power, they raised municipal workers' salaries very high - so the participatory budget commenced during a period of financial crisis for the city hall... the first participants in the participatory budget were expecting results from the participatory budget, 
but the government had no money. People wanted to see results.

Fortunately, as I have described earlier, the PT municipal government was able to raise money and people were able to start seeing results; the effect of this (rising participation) can be seen in Figure 6.3.

However, from what I ascertained during my time in Porto Alegre, it appears that the participatory budget is starting to experience a new financial squeeze; in the current budget less money is available for new investments than in previous years. This decrease in available money is the result of several factors. Firstly, as Baierle (2003, p. 9) notes, at the beginning of the 1990s cities controlled 17 percent of the national budget (this relatively high level was the result of constitutionally mandated decentralisation), however, during the Cardoso years a process of re-centralisation began to take place meaning that by the end of the 1990s cities only controlled 14 percent. Sergio Baierle outlined the second problem - economic recession - in his interview with me:

One problem is that we have a recession of the internal markets...this is important, as a significant share of the local budget comes from the internal share of goods.

The third problem is debt repayment, as Baierle (interview notes) noted:
Also they [the city hall] started paying off some debts - they do not have a huge debt but recently they made some debts for infrastructure like building a city ring road - and now they have to pay their share of this.

The final problem that interviewees raised could almost be termed the participatory budget becoming a victim of its own success'. What has happened is that, amongst the abundance of new investments which have resulted from the participatory budget, there have been a considerable number that have had ongoing costs associated with them (schools, crèches, medical centres, etc.) These ongoing costs, in turn, diminish the proportion of the annual budget available for new investments (Sergio Baierle, interview notes; Luis Alberto Giradi, interview notes; Alexandre Stolte, interview notes).

As Luis Alberto Giradi, stated in his interview: 
The people meet to discuss how to spend the money - but they do not know where it is coming from. They have been educated about how to spend the money but they have not been educated about where the money comes from and how to get resources.

Giradi also provided what he thought might be a solution to this dilemma:

So at this stage we are trying to educate the public to discuss where it might get the money from that it wants to spend on municipal resources. It is a discussion that has to be provoked as since 1991 the people have not had to think about this, there has always been a reasonable amount of money available.

Alexandre Stolte - a senior GAPLAN planner - also made a similar comment when discussing the new financial squeeze:

It is difficult to make people understand that they have to consider where the money is coming from. But I think it is possible.

\subsubsection{External Problem - Resistance from Elites}

The hostility of local political elites to the participatory budget has been another problem that the process has had to face in Porto Alegre. Initially, the participatory budget was remarkably lucky as the city's local political elites almost completely ignored the process, unaware of its transformative potential (Abers 2000; Goldfrank 2003). This is important because it enabled the process to become established without too much opposition from power-holders; opposition which might have destroyed the participatory budget in its first few tentative years. However, as local elites became aware of the participatory budget in Porto Alegre, and particularly since the programme became the PT's flagship project, they have increasingly directed hostility towards it (Wainwright 2003). This hostility has come in two main forms: hostility from the media and hostility from city councillors.

The elite-controlled local media has attempted to hinder the participatory budget by either boycotting it or directing critical coverage at the process (Baierle 2003). While, at the same time, conservative city councillors have tried to thwart the passing of budgets 
through the legislative process by requesting amendments to them (Sousa 2001). It is interesting to note, however, that councillors are very reluctant to actively vote against the budget as they do not want to be seen as opposing the public voice (Abers 2000).

\subsubsection{Internal and External Problem - Completing Works on Time}

One internal problem, or at least a perceived problem, that has affected the participatory budget in Porto Alegre has been delays in getting works completed on time. As Abers noted in her interview:

Everyone was always complaining about works not being completed on time in Porto Alegre.

However, it is important to note that there is no evidence that the participatory budgeting process itself causes the projects to be delayed; rather, it would appear that the delays are the result of local bureaucracy and the usual difficulties associated with municipal works. Abers also makes a very important point that:

You know what, before the participatory budget in Porto Alegre and Belo Horizonte budgets were not itemised, so nobody even knew what was scheduled to go ahead that year. There could not be any delays because there were not any deadlines.

In other words the transparency of the participatory budget makes people aware of delays that might otherwise have occurred - or been worse - anyway.

\subsubsection{Internal Problem - Lack of Technical Input and Centralised Planning}

One more significant internal problem with the participatory budget was that, particularly in early years, projects were undertaken without considering the flow on effects that they might have on other parts of the city or on other aspects of municipal service provision. Sergio Baierle commented on this problem in his interview:

For example, in the beginning, to circumvent the state bureaucracy, the local government bureaucracy, they created a planning cabinet aside from the planning department and linked it directly to the mayor. So it was a way to circumvent 
bureaucracy and to make things work. But they forgot to pay attention to some aspects of planning that should have been considered. For example, the option of paving city streets with asphalt created a lot of city streets that were impermeable, so in rainy seasons you have some floods affecting the areas. The same with sewerage pipelines, we created many kilometres of sewerage pipelines, but not the facilities for sewerage treatment. So the consequence was that we were discharging more and more effluent into the lake.

It is worth noting that since Tarso Genro's term in power, the city hall has put more emphasis on considering the technical feasibility of projects before they go ahead, rather than simply acquiescing to participants' demands (Abers 2000). However, Baierle has argued - both in his interview with me and also in written work (Baierle 2003) - that this lack of central planning is still a problem.

\subsubsection{Internal Problem - Low Participation in Some Middle Class Neighbourhoods}

Although no interviewees or much of the literature made mention of it, there seems to be some evidence that low participation in some middle class neighbourhoods has been a problem for the participatory budget in Porto Alegre. In particular, Abers (2000) - who has undertaken probably the most in depth study of the participatory budget in Porto Alegre - discussed the problem of a particular middle class neighbourhood, where low participation levels meant that they were invariably being 'out competed' for projects by other, nearby, working class neighbourhoods. Predictably, residents of the middle class neighbourhood became disillusioned with the process and it was only when the neighbourhood became reallocated into an administrative zone with other middle class neighbourhoods that participation levels began to rise.

\subsubsection{Problem/Limitation - Land Tenure}

One significant limitation that has affected the participatory budget's ability to provide for Porto Alegre's least well off is the fact that many of the city's favelas are constructed on land that has been illegally occupied. Baierle (2003, p. 319) states that illegal settlements are home to as much as 25 percent of Porto Alegre's population. This is problematic as Márcia da Silva Quadrado, explained in her interview: 
Porto Alegre has many people living on land that is not legally theirs. The city hall cannot legally perform works on this land. If the city hall invests money in land that is not legally occupied, the legal owner of the land can take the council to court. So GAPLAN is very careful when it receives a demand, to find out whether the area they are building on is legally occupied or not.

The municipal government in Porto Alegre has initiated a programme of land ownership regularisation (giving the squatters legal title or moving them elsewhere) so it can overcome this problem, however, this process is very slow and so far has only dealt with a very small proportion of Porto Alegre's illegally occupied land (Baierle 2003).

\subsubsection{Limitation - "Porto Alegre is Still a Third World City"}

The land legalisation issue ties into a much larger limitation to what the participatory budget can accomplish: the fact that the participatory budget is a process operating at a city level in Brazil, a country with huge national levels of poverty and inequality, that is integrated into a global economy plagued by speculation and crisis. In other words, there is only so much that the participatory budget can do; beyond that, the welfare of Porto Alegre's citizens relies on decisions made at a national and even a global level. As Wampler (2002, p. 230) states:

While PB [participatory budget] participants dedicate their efforts to securing changes in local public policies, the principal problems their communities face are often related to unemployment, violence, or the lack of educational opportunities. This should be considered a limitation because the $\mathrm{PB}$ program does not provide the opportunity for participants to challenge the underlying reasons for their social and economic exclusion.

Baierle (2003, p. 310) makes a similar point:

However good local policies of social assistance and job creation may be, there exist harsh limits in the economic system which constantly intensify social exclusion...A March 
2001 study comparing the periods of 1981-85 and 1995-99

shows a deterioration in the indices of employment and

income, despite advances in the area of education and health.

Or as Marcelo Kunrath Silva stated in his interview, "Porto Alegre is still a third world city."

\subsection{Uncertainties}

The primary area where the results of the participatory budget in Porto Alegre could be described as 'uncertain' relates to the way that the budget process has interacted with civil society ${ }^{15}$ and government in the city. In particular there are three components of this interaction which remain difficult to resolve completely: the creation of a new breed of civic activists and the limitations of these activists; the potential for the participatory budget to be manipulated by various interests; the potential for civil society to be weakened or made dependent on the government by the participatory budget.

\subsubsection{New Civic Activists and their Limitations}

There appears to be little doubt that the participatory budgeting process in Porto Alegre created a new generation of civic activists. Abers (1998, p. 530) as part of her very comprehensive study of the participatory budget noted that in 1989, 60 percent of budget participants lived in the six districts of the Porto Alegre that had a history of protest orientated neighbourhood activism, while only 40 percent came from the other ten districts (which had little activist history). However, by 1995, this picture had changed dramatically with 62 percent of participants now coming from the ten districts with little previous activist history. In other words, by demonstrating that action and involvement could have tangible results, the participatory budget encouraged organising in areas that previously had very little history of such activism (Avritzer 1998).

\footnotetext{
${ }^{15}$ The London School of Economics' (LSE) Centre for Civil Society defines the term Civil Society as, "the arena of uncoerced collective action around shared interests, purposes and values. In theory, its institutional forms are distinct from those of the state, family and market, though in practice, the boundaries between state, civil society, family and market are often complex, blurred and negotiated. Civil society commonly embraces a diversity of spaces, actors and institutional forms, varying in their degree of formality, autonomy and power. Civil societies are often populated by organisations such as registered charities, development nongovernmental organisations, community groups, women's organisations, faith-based organisations, professional associations, trades unions, self-help groups, social movements, business associations, coalitions and advocacy groups." My use of the term Civil Society in this dissertation is consistant with the LSE definition. (London School of Economics, 2004)
} 
However, more recent works seem to indicate that there are limitations to the activism that has been generated by the participatory budget. Wampler (2002) discusses how neighbourhoods he has studied mobilised for the purpose of obtaining specific material goods then, once these goods were obtained, communities ceased participating in the budget process. Moreover, Wampler (2002; p.228) added:

Many participants are less interested in learning about rights, about the fiscal responsibility of the government or broader social policies than they are interested in obtaining a small infrastructure project.

Wampler (2002 p.228) goes on to describe this as the "principal Catch-22 of the program". To Wampler (and many interviewees agreed with this) the main reason for the success of the participatory budget is that participants can see tangible results as a reward/incentive for their participation. However, the adverse side effect of this according to Wampler (2002; p.228) is:

It associates PB [participatory budget] programs with the distribution of specific goods, which limits the overall impact on public learning.

This would appear to indicate that there are significant limitations to the transformative power of the participatory budget in Porto Alegre. However, it should also be pointed out that both the thematic assemblies and the city conference (which is held periodically) obtain reasonable levels of participation despite the fact they are not based around shortterm tangible goals. The 2000 city conference had 8,780 participants (Menegat 2002, p. 196). So, at least some of the participatory budget participants in Porto Alegre are participating for reasons other than short-run self-interest.

\subsubsection{Manipulation}

The second uncertain area is how prone the participatory budget in Porto Alegre has been to political manipulation. The conservative city councillor who I interviewed charged that the process was "politically manipulated" and, while none of the other interviewees agreed with this they, along with much of the literature, did note the potential for participation to be co-opted by the government or other political agents. 
Several authors discussing the participatory budget in Porto Alegre have noted that the stage of the participatory budget when the Budget Council negotiates the final budget with municipal staff is problematic and, within it, there exists the potential for manipulation (Abers 2000; Shah \& Wagle 2003). In particular, Budget Councillors have complained that technical information or the justifications for vetoing a project on technical grounds are often not explained clearly by municipal staff, potentially enabling the government to act against projects that it is not favourably disposed to despite the fact that they are technically viable (Abers 2000). Abers in an interview with me also stated that:

Thematic city-wide assemblies are much more problematic projects are typically longer than one year, they are more complicated issues, more negotiation with the authorities is necessary, state expertise might be important (although participants can be experts), the cost of errors is higher for large projects.

So, once again, the potential for manipulation. However, it is important to note that, as far as evidence goes, it is only the potential for manipulation that has been identified. Although this area has not been properly studied, there is little evidence to show that it is actually taking place. It is also important to note that the PT government has made concerted efforts to make municipal engineers and technocrats more adept at presenting technical information clearly as well as being more receptive to the ideas of participants (De Sousa Santos 1998). It seems unlikely that a government keen on politically manipulating a process would also be trying to actively limit the areas where it has the ability to do this.

There also exists a risk of the participatory budgeting process being manipulated at the community level, although in this case, the potential perpetrator of the manipulation is not the government but rather independent agents who seek to use the participatory budget for their own means. Shah \& Wagle (2003) state that there have been questions asked (particularly relating to the thematic process) about whether budget delegates accurately reflect public opinion. Moreover, both Abers (2000 and interview notes) and Baierle (interview notes) cited cases of community activists attempting to manipulate the participatory budgeting process to provide a political springboard for their political 
careers or to obtain personal material benefits ${ }^{16}$. Along these lines, in his interview with me, Luis Alberto Giradi mentioned that:

\begin{abstract}
What happens within a community could be potentially undemocratic practice. How do they choose the projects they want and their delegates? This should be an open process but it is not in a lot of communities. Yet the government feels that it shouldn't intervene - this would be counter to the spirit of the participatory budget.
\end{abstract}

So it would seem, although there are no studies to my knowledge that look into this problem in any detail, that within communities there exists some potential for manipulation of the process to occur. This affects, not only the process through which projects are selected, but also in some cases the implementation of the projects themselves - as Baierle (2003, p. 311) notes with regards to the creation of community run crèches:

How can it be guaranteed that the professionals who are hired are not relatives of the leader of the community organisation?...How can it be guaranteed that the criteria for registration and length of stay of children are equitable and unbiased? How can it be ensured that public money is managed in a transparent fashion and with the agreement of parents and the community?

None of this is to say that everything that takes place at a community level will be corrupt, in many ways Brazilian neighbourhoods operate in a less corrupt manner than almost all other levels of Brazilian society. However, the opaqueness of what takes place at a community level does seem to be a potential problem area for the participatory budget in Porto Alegre.

\title{
6.10.3 Civil Society: Weakened and Dependent?
}

The final area of uncertainty regarding the participatory budget in Porto Alegre relates to whether the process has actually weakened civil society in the city and made it dependent

\footnotetext{
${ }^{16}$ It is interesting to note that the case that Abers discussed with me involved a member of the PDT (one of the PT's political rivals) trying to use the participatory budget to establish himself as a local politician.
} 
on the municipal government. When asked about this outcome in his interview Sergio Baierle stated:

Yes because all the process of participation is now taking place in the city hall so there is a lot of conferences, of meetings, of seminars. For every topic you can imagine, from education, housing health, the environment, all the areas of the government we have in Porto Alegre...We have a council for health, for housing, all the schools have community councils to help in running them. So the spaces created by the city hall absorb all the energies of the social movement...and in the research we did, we saw that people for example, before the participatory budget started there was the Union of Vilas [a favela based organisation] and now the Union is aggregating less people than they were aggregating before...

It is important to note that some of the councils that Baierle talks about above are not actually directly related to the participatory budget, but are part of a broader PT programme in Porto Alegre to encourage consultation between civil society and the government. However, the participatory budget is part of this programme and there does seem to be some evidence (as he suggests) that much of civil society's energy - which was once engaged in autonomous and often confrontational actions - has now been integrated into the government sphere.

I believe that it would be a mistake to see this as a completely, inherently, bad outcome after all, conflictual posturing can only achieve so much, while working within the system can produce many benefits, especially when the system seems to be genuinely focused on tackling the city's problems. However, governments change and even those that stay in power can drift from a genuine focus on solving problems to being more concerned with defending their own political territory; so it would be worrying if the PT ultimately brought about the demise of autonomous civil society in Porto Alegre.

This has not happened yet, and in my opinion, the end result of the participatory budget's influence on civil society is far from clear; it remains a question that only time and more research can answer. 
As I have mentioned, the above processes are complex and, at a cursory glance, some of the claims made in this sub-chapter seem to be contradictory. However, it seems likely that rather than contradict each other, the differing opinions that I have represented simply reveal different slices of a very complex picture. In his interview, Marcelo Kunrath Silva made a statement that illustrates how the outwardly paradoxical can actually be complementary:

In one sense I guess that Rebecca [Abers] is right: the participatory budget stimulated the creation of social groups. The participatory budget fortified civil society. But also weakened it because it made civil society dependent on the government.

\subsection{Conclusions}

This chapter has detailed the results of my research on the participatory budget in Porto Alegre. From these results several clear conclusions can be drawn about the participatory budgeting process in the city. The first is that participatory budgeting has had tangible and significant successes in Porto Alegre: it has succeeded in providing municipal services to areas that have previously been deprived of them; it has dramatically reduced clientelism and corruption; it has assisted the PT to be re-elected three times; and it has opened up a space for non-elite political participation. While Porto Alegre is, by Brazilian standards, a wealthy city with an educated populace, it is still a Brazilian city - a major proportion of its population live in favelas and its political history has been one of elite dominance. Set in this context, the achievements of participatory budgeting in Porto Alegre are indeed significant and worthy of the attention that has been directed at them.

These successes have not come easy though; as I showed in the problems and limitations sub-chapter, a variety of constraining factors, ranging from a lack of money to hostile elites, have hindered the operation of the participatory budget in Porto Alegre. The existence and impact of these constraining factors leads to my second conclusion: participatory budgeting is not impervious to the local context in which it operates, and a variety of local factors can and will influence its outcomes.

In the next chapter of this dissertation, I move on to analyse the participatory budgeting process in Belo Horizonte. This analysis is undertaken with the intention of enabling a comparison of the two cities and their participatory budgeting experiences which, in turn, 
will allow me to draw a more detailed picture of just which local factors are significant in determining the outcomes of participatory budgets. 


\section{Chapter 7 - The Participatory Budget and Belo Horizonte}

\subsection{Introduction}

In the previous chapter I described the participatory budgeting experience in Porto Alegre. In this chapter, I undertake the same analysis for Belo Horizonte. First I detail Belo Horizonte's salient characteristics, its history and the history of the PT in the city. I then provide an explanation of how the participatory budgeting process works in Belo Horizonte, as well as a description of how the process has developed over the years. Finally I outline the successes of, problems experienced by, and limitations to participatory budgeting in Belo Horizonte.

\subsection{Belo Horizonte}

Belo Horizonte (the name translated literally means Beautiful Horizon) is located in Brazil's centre-south, in the state of Minas Gerais. Surrounded by a large agricultural hinterland, Belo Horizonte obtains a significant proportion of its wealth from the extensive farming and mining activity that takes place in the surrounding countryside. Belo Horizonte is also home to a significant amount of industry, and is Minas Gerais' banking and commerce hub (Encyclopædia Britannica 2004c).

Figure 7.1 - Belo Horizonte Located on a Map of Brazil

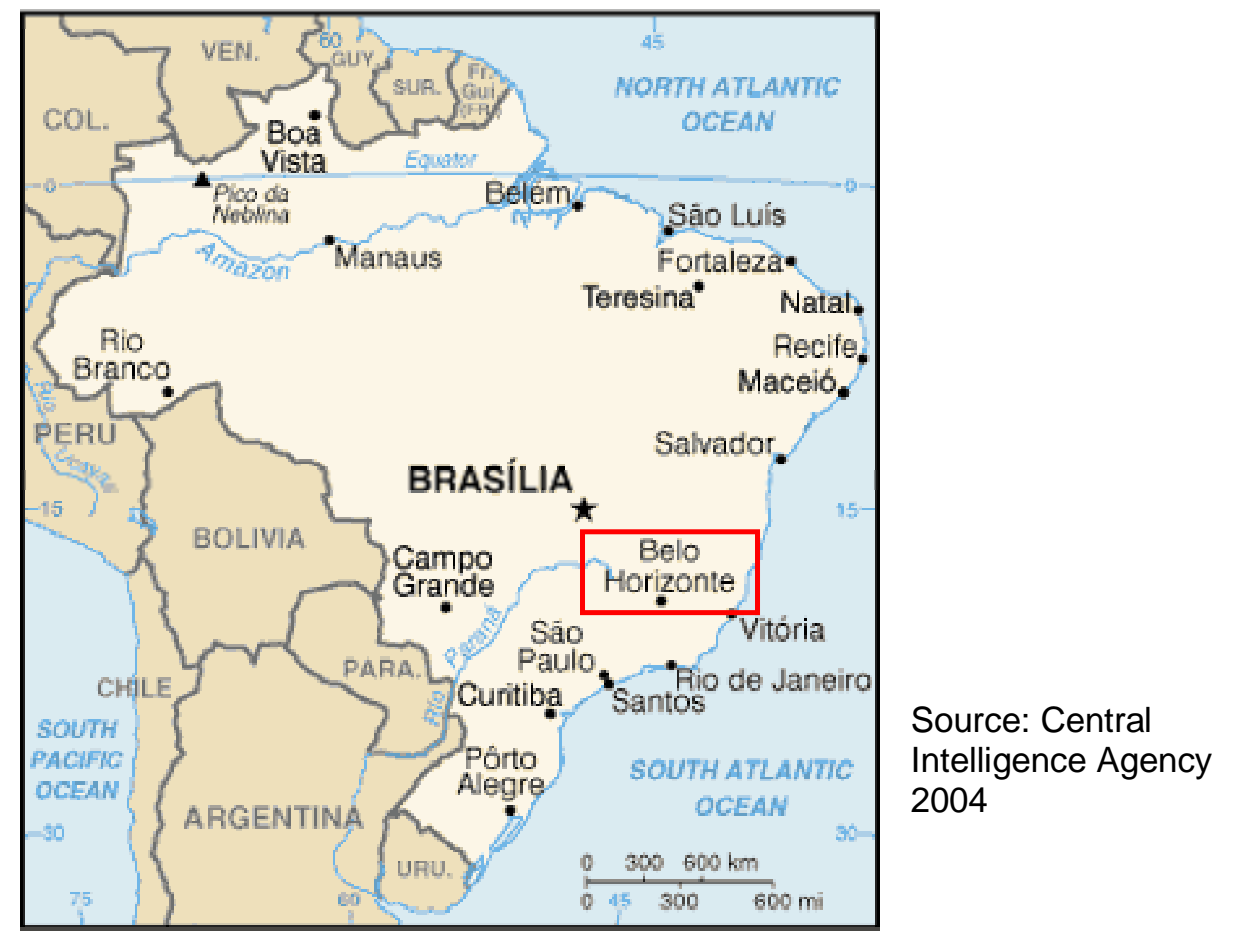


In the year 2000, the city of Belo Horizonte was estimated to have a population of 2,238,526. The greater metropolitan region of Belo Horizonte was estimated to be home to about 4,259,163 people (UNDP Brazil 2000).

In 1991 Belo Horizonte had a HDI of 0.791 and by 2000 this had increased to 0.839 (UNDP Brazil 2000). Belo Horizonte's 2000 rating placed it slightly above the median HDI for Brazilian cities of more than 1,000,000 population (for a comparison see Chapter 6 - Table 6.1) (UNDP Brazil 2000).

In the year 2000, per-capita income in Belo Horizonte was 557 PPPU and its Gini coefficient was 0.62. Belo Horizonte's per-capita income is just above the median for Brazilian cities of more than 1,000,000 population, while its Gini coefficient is exactly on the median (along with São Paulo and Rio de Janeiro) (for a comparison of incomes and Gini coefficients for large Brazilian cities see Table 6.3) (UNDP Brazil 2000).

\subsection{The History of Belo Horizonte}

In the late 1600s prospectors discovered gold in Minas Gerais, triggering a gold rush that was to unearth a staggering mineral wealth and transform the area from a remote backwater into one of the centres of the Brazilian economy. Initially, the urbanisation caused by the influx of immigrants to Minas Gerais was focused on towns nearby the gold-rich parts of the state, however, as Ouro Preto - the largest gold rush town - was constrained from significant growth by unfavourable geography, the decision was made to create Belo Horizonte - a pre-planned city - as Minas Gerais' state capital. Modelled to an extent on the grid-like pattern of Washington DC, Belo Horizonte was initially designed to occupy an area of 20 square $\mathrm{km}$ and be home to 200,000 people. However, the city rapidly outgrew its planners' expectations - its population exceeded 200,000 in 1925 (Encyclopædia Britannica 2004c) and the city continued to grow, particularly during the period from 1950 to 1980 when its population increased from 352,000 to $1,780,000$ (Avritzer 2002, p. 2). Much of this immigration came from the poorer rural areas of Minas Gerais and the migrants themselves were typically from lower socio-economic, marginalized sectors of society. By 1960 there were already 70 favelas in existence in Belo Horizonte; these favelas were home to more than 25,000 people (Avritzer 2002, p. 3). Most of the people who immigrated to Belo Horizonte during this period were descendants of Portuguese settlers; a smaller minority of immigrants were of mixed African/European/Indigenous Brazilian heritage (Encyclopædia Britannica 2004c). 
Mineral and agricultural wealth made Minas Gerais one of Brazil's most politically powerful states, and for many years leading up to the military coup that put Getúlio Vargas into power members of the Minas Gerais elite colluded with those of the São Paulo elite to ensure their candidates became the country's presidents. During the Vargas years, as well as the democratic and dictatorial epochs that followed, Minas Gerais' national political power decreased to a degree, however, within the state itself, powerful oligarchs retained their iron rule and the prevailing political culture was strongly conservative (Hagopian 1996). One particular tool that the state's oligarchy used to cement their control on power was to make large cities such as Belo Horizonte dependent on the Minas Gerais state government for much of their municipal revenue (Hagopian 1996).

Historically, Belo Horizonte's poor were only very minimally politically organised and the result of this was that the post 1964 military regime was able to relocate the city's inner urban favelas to new locations on the metropolitan perimeter with very little resistance. Municipal services were either very minimally provided to these new peripheral favelas or not provided at all (Avritzer 2000). However, from the mid 1970s throughout the 1980s Belo Horizonte's political culture started to change. Like all large Brazilian cities, Belo Horizonte became home to a significant movement of opposition to military rule and, in addition to this, there was a dramatic growth in neighbourhood and community organisations. From the 1920s to the 1970s only 71 neighbourhood organisations were formed in Belo Horizonte, however, during the 1970s and 1980s the number of residents associations in the city grew from 71 to 534 (Avritzer 2000, p. 4). Many of these new residents associations were combative, demanding the legalisation of land title in informal settlements, the improvement of urban infrastructure, and the increased provision of health and education services (Avritzer 1998; Avritzer 2000). The rise of combative residents associations represented a significant challenge to the prevailing way of getting things done at a neighbourhood level in Belo Horizonte, which was clientelism (Avritzer 2000; Hagopian 1996). However, despite the rise of this new form of civic activism, clientelistic practices still remained the tool used by the majority of community organisations in the city to obtain public goods (Avritzer 2002c).

Initially, after the re-democratisation of Brazil, city politics in Belo Horizonte were dominated by the existing political elites (Hagopian 1996). One thing that did change during this period of rightwing or centre-right rule was that the municipality of Belo Horizonte was able to dramatically increase its revenue intake (Souza 2001). A significant proportion of this increase was the result of the constitutionally mandated political 
decentralisation of Brazil; however, much of the additional money came from the raising of local taxes (Souza 2001).

In 1992 an alliance of leftwing political parties with the PT at its head won the mayoral elections for the city of Belo Horizonte. Patrus Ananias of the PT became the city's mayor (Feres Faria 1996; Nylen 1999).

\subsection{The PT in Belo Horizonte}

Historically, Minas Gerais was a conservative state with little history of strong leftwing political parties. However, as in other parts of the country, a significant resistance movement - which was broadly based around leftwing principles - to the military dictatorship began to arise in Belo Horizonte during the 1970s and 1980s (Neusa Cardoso de Melo, interview notes). In Belo Horizonte the PT was born primarily from this resistance movement. The PT initially began as only a minor party in Minas Gerais (winning 7 out of 723 mayoralties in 1988) (Hagopian 1996, p. 215), however, its popularity grew and, by the time of the 1992 elections, the PT was the most significant party in the 'Frente Popular' coalition that won the mayoral elections ${ }^{17}$.

When the PT mayor, Patrus Ananias, took power in 1992 he inherited an administration that was in some financial difficulty (Rodrigo Barroso, interview notes), however, the situation was nowhere near as dire as that experienced in Porto Alegre and Ananias was able to begin implementing the participatory budget during his first year in office (Souza 2001). The main problem that the PT faced in Belo Horizonte was political infighting as well as fighting with other members of the Frente Popular coalition. This conflict reached a crisis point when Patrus Ananias nominated his vice-mayor, Célio de Castro, who was a member of the Brazilian Socialist Party, as his preferred candidate to replace him. However, the PT's local leadership and members voted to run their own candidate; a move which Nylen $(1999$, p. 27) claims struck many observers as "insulting to both Patrus and Castro". In many ways this split was symptomatic of the type of tensions that have, all too often, plagued the PT in municipal government (see Chapter 5.3 for a fuller explanation of this). Ananias had already been in conflict with the party's local hierarchy and his support of a mayoral candidate from another party was the final straw for local leadership, which decided to act against their mayor's wishes ${ }^{18}$. The move was a

\footnotetext{
${ }^{17}$ The other parties in the 'Frente Popular' were the Brazilian Socialist Party, the Brazilian Communist Party, the Communist Party of Brazil and the Green Party (Feres Faria 1996).

${ }^{18}$ Ananias did remain within the PT though and now occupies a prominent position in the Federal Government in Brasilia.
} 
potentially disastrous one for the Belo Horizonte PT, Ananias was an extremely popular mayor - he had an 85 percent public approval rating - (Nylen 1999, p. 27) and Castro (who was also popular) was able to campaign as Ananias' chosen successor. Moreover, absence of PT support for Castro meant that Castro had to form a tactical alliance with the centre-right Party of the Brazilian Democratic Movement, potentially ending the left's control of the city hall and its functions (including the participatory budget) (Nylen 1999).

However, fortunately for the PT and the participatory budget, upon Castro's victory in 1996, relations between Castro and the PT were patched up, and PT supporters were placed in positions of power within the new administration (Avritzer 2000; Nylen 1999; Souza 2001). Importantly, the new administration continued the participatory budget and in 2000 the PT won the mayoral elections guaranteeing the budget's continued operation (Avritzer 2002).

\subsection{The Participatory Budget in Belo Horizonte}

As in Porto Alegre the participatory budget in Belo Horizonte has been a reflexive process, one that has been adapted in response to existing problems and new ideas. Because of this, the participatory budgeting process in Belo Horizonte is now significantly different from the one introduced to the city in 1993. An explanation of how and why the participatory budget has changed over time in Belo Horizonte is covered later in this chapter (Sub-chapter 7.6); this current sub-chapter limits itself to discussing how the participatory budget operates at present.

\subsubsection{What is actually decided?}

Up for decision in the participatory budget is 50 percent of Belo Horizonte's biannual budget for new investments. For the 2003/04 participatory budget process $\mathrm{R} \$ 91,150,000$ was available for investment ${ }^{19}$ (Prefeitura de Belo Horizonte 2004, p. 15).

\subsubsection{A Parallel Democratic Process Held Every Two Years}

As in Porto Alegre, the participatory budget has not replaced normal democratic process in Belo Horizonte, and every four years the city still votes for the mayor and the city councillors. The participatory budget sits parallel to this existing democratic process; the final municipal budget in Belo Horizonte is still ratified by the city council. The participatory budget in Belo Horizonte is held every two years.

${ }^{19}$ On the $6^{\text {th }}$ of August $2004 \mathrm{R} \$ 91,150,000$ was worth $\$ 29,705,067$ US. 


\subsubsection{Government Co-ordination Body}

In Belo Horizonte overall co-ordination of the participatory budget is undertaken by an organ called the Planning Department (Avritzer 2000). The Planning Department is also responsible for turning the participants' demands into a technical budget. A subdepartment of the planning department is responsible for co-ordinating popular participation (Avritzer 2000; Maria Auxiliadora Gomes - who is the Public Participation Co-ordinator for the participatory budget - interview notes).

\subsubsection{Regions, Sub-regions and two Rounds of Participation}

For the purposes of the participatory budget, Belo Horizonte is divided by the municipal government into nine administrative regions. The regions themselves are further subdivided into sub-regions (Prefeitura de Belo Horizonte 2003; Prefeitura de Belo Horizonte n.d.).

The first round of participatory budgeting meetings take place at a regional level (they are open to all residents of that region). In these meetings, representatives of the city hall inform participants about the general guidelines for the participatory budgeting process as well as advising them about how money allocated in the previous budget was spent (Avritzer 2000; Prefeitura de Belo Horizonte n.d.).

After this initial round of regional meetings, participants then return to their neighbourhoods and decide on priority projects for their neighbourhood (there will be several neighbourhoods in each sub-region). These neighbourhood-level demands have to be decided on at a community meeting and must be accompanied with minutes from that meeting as well as signatures of 10 participants (Prefeitura de Belo Horizonte n.d.; Paula Romanelli Simões and Gilma Carmélia Alves dos Santos - participatory budget coordinators - interview notes).

This intermediate neighbourhood stage is followed by the second round of assemblies, this time held at a sub-regional level. At these assemblies participants are advised of the amount of money allocated to their region for participatory budget spending. The distribution of available money across the regions is based on a variety of factors:

- 50 percent of available funding is spread evenly across the city's regions. 
- The other 50 percent is allocated by a formula that takes into account population as well as an index score for each region. The index score is based on the quality of life (including things such as provision of services to the region).

- Participation is also a factor although only weakly. Participation only affects the level of funding a region will get if a minimum level of participation is not achieved. When this occurs a proportion of a region's funds (but not all) are be redistributed to other areas.

(Avritzer 2000; Prefeitura de Belo Horizonte n.d.; Paula Romanelli Simões and Gilma Carmélia Alves dos Santos, interview notes)

At these second-round sub-regional meetings delegates for the sub-region are elected and projects for the sub-region are proposed. Via the sub-regional process a total of 25 projects are selected for each region (Prefeitura de Belo Horizonte n.d.). After a region's projects have been identified, city officials visit all the of the proposed project sites to develop a technical appraisal of the viability of the proposals.

The next step of the participatory budgeting process is called the 'Caravan of Priorities' and takes place at a regional level. In the Caravan of Priorities, each region's delegates are taken to see all of the works proposed for their region (i.e. they visit the projects proposed by other sub regions within their region). The purpose of the 'Caravan of Priorities' is to encourage a spirit of 'abre mão' (literally an “opening of hands") or altruism amongst the delegates before they decide - in the next round of the process - which 14 (of the original $25)$ projects are to go ahead in their region. The rationale behind this attempt to encourage altruism is that, when delegates visit proposals from more needy areas in their region and see the need for the projects, they will be more inclined to choose projects considering more than just their own sub-region's proposals (Paula Romanelli Simões and Gilma Carmélia Alves dos Santos, interview notes; Prefeitura de Belo Horizonte n.d.).

After the Caravan of Priorities, each region's delegates meet and vote for a slate of 14 projects to go ahead in their region. It is important to note that in voting, delegates do not vote for individual projects, rather, they choose from competing lists made up of different projects, the cost of which total, more or less, the available budget for the region (Paula Romanelli Simões and Gilma Carmélia Alves dos Santos, interview notes; Prefeitura de Belo Horizonte n.d.). As well as voting for the projects for their region, delegates elect their regional representatives to the 'Comforça', a council that works with the 
municipality to create the final, detailed, budget plan. Members of the Comforça also remain active over the following two years monitoring the contracting and constructing of the proposed projects (Prefeitura de Belo Horizonte n.d.).

\subsubsection{Incorporating the Middle class and the Marginalized}

The participatory budget in Belo Horizonte has two special features that are integrated into the process described above. The first is that particular areas within each sub-region are identified as extra-needy and worthy of priority attention. These areas (typically they are neighbourhoods) are identified by indexing the following indicators: proportion of population living below the poverty line, illiteracy rate, low levels of participation in education, inadequate municipal services, and poor health indicators. Once identified, priority areas are given an additional weighting when the participatory budget is allocated to the different regions (i.e. regions with higher numbers of these priority areas receive disproportionately high funding allocations). Some funding is also allocated directly to the priority areas (through guaranteed projects). The rationale behind this process is to both provide additional assistance for previously neglected areas and to encourage participation from the city's most marginalized classes, who had previously been under-represented in the participatory budgeting process (this is discussed more below) (Prefeitura de Belo Horizonte n.d.).

Like the sub-poor, Belo Horizonte's middle class has, in the past, also been underrepresented in the participatory budgeting process. To ensure that middle class neighbourhoods are not excluded from the process, middle class neighbourhoods are grouped together into sub-regions of their own, meaning that they are not competing with better organised, working class neighbourhoods for projects (Prefeitura de Belo Horizonte n.d.).

Figure 7.2 shows diagrammatically how the participatory budgeting process in Belo Horizonte operates. 
Figure 7.2 - The Participatory Budget in Belo Horizonte

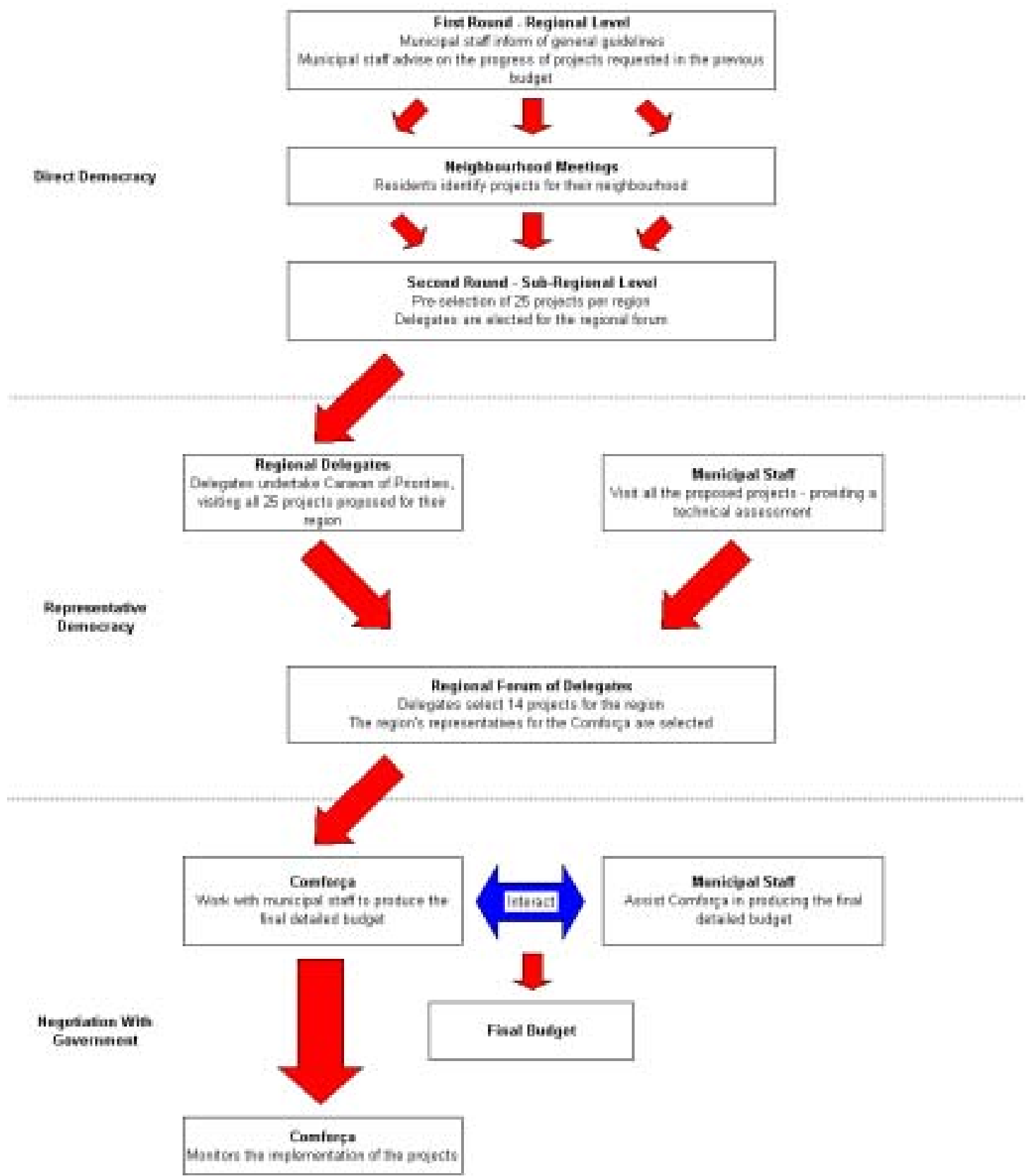

Source: Prefeitura de Belo Horizonte n.d., p. 10 and my own field research

\subsubsection{Parallel Participatory Processes}

As well as the regional participatory budgeting process, there are two additional participatory processes operated by the municipal government in Belo Horizonte. The first is the Housing Forum, in which members of Belo Horizonte's homeless organisations meet to decide how a specially allocated budget for housing construction will be spent. The housing conference takes place every two years (like the participatory budget). The second parallel process is the Belo Horizonte City Conference where residents of Belo 
Horizonte meet to discuss future city-wide directions for the city. This process has been held twice so far - in 1999 and in 2003 (Prefeitura de Belo Horizonte n.d.).

\subsection{The Participatory Budget as an Evolutionary Process}

Since the participatory budget's inception in Belo Horizonte in 1993 there have been several significant changes made to the budgeting process. The changes, along with the rationale for them, are listed below:

- Initially the Planning Department, responsible for administering the participatory budget, was part of the Mayor's office and had only four or five staff working for it. Clearly this was not an adequate resource allocation for the operation of something as complex as the participatory budget and consequently the department was given its own separate identity and more staff and resources (Paula Romanelli Simões and Gilma Carmélia Alves dos Santos, interview notes).

- In 1994 Belo Horizonte introduced thematic fora similar to those used in Porto Alegre, however the fora were only of a consultative nature and were poorly attended - as a result of this the fora were discontinued and one single forum - the Housing Forum (described above) was established. The housing forum was established as the result of pressure from the homeless movement who, presumably, were excluded to a degree from the existing regional process (Souza 2001).

- There were three rounds of assemblies in the regional process until 1999 when the number of assembly rounds was reduced to two (Avritzer 2000). It appears that this change was made to improve the efficiency of the participatory budgeting process.

- In 1999 the government introduced the first 'City Conference' (Prefeitura de Belo Horizonte n.d.).

- In 2000 the participatory budgeting process was changed from an annual process to a bi-annual process. The reason for this change was that it left more time for projects to be completed and also provided for a larger sum of money to be available each budget period (both changes that will better facilitate larger projects) (Clarice Barreto Linhaus and Roberto Rocha Coelho Pires - who are researchers at the Federal University of Minas Gerais - interview notes; Paula Romanelli Simões and Gilma Carmélia Alves dos Santos, interview notes). 
- In $2000 / 01$ the unit for calculating the 'neediness' of an area was changed from average household income to the quality of life index that I described while detailing the current functioning of the budget. The reason that the government made this change was that - in their experience - average income had proven to be a relatively poor approximation of an area's need for municipal service provision. The quality of life index, on the other hand, was a more detailed measure, which they hoped would reflect more accurately the need for municipal investment in different areas (Paula Romanelli Simões and Gilma Carmélia Alves dos Santos, interview notes).

- Another change that took place over 2000/01 was the redistricting of the budget subregions. The sub-regions were altered so that they became smaller and borders were re-drawn so that the sub-regions were more socio-economically homogenous (i.e. very poor neighbourhoods were no longer included in the same sub-regions as very wealthy neighbourhoods). The main rationale for this was that - as I touched on earlier and will describe in more detail below - different socio-economic groups have had highly varying levels of participation in the past. It was hoped that redistricting would mean that less well organised groups would no longer be marginalized from the participatory budgeting process because they were unable to successfully compete for projects with their more well organised neighbours (Rocha Coelho Pires 2001; Maria da Paixão Dias - member of the NGO Musa and budget participant - interview notes).

\subsection{A Note on the Outcomes of the Participatory Budget in Belo Horizonte}

So far in this chapter I have described Belo Horizonte, the history of the PT in Belo Horizonte and the way that the participatory budget works in Belo Horizonte; the chapter now moves on to detail the outcomes of participatory budgeting in the city. The outcomes are grouped under three headings: successes, problems and limitations, and uncertainties.

\subsection{Successes of Participatory Budgeting in Belo Horizonte}

\subsubsection{Provision of Municipal Services to the Previously Excluded}

The provision of municipal services to those who had previously been denied them was one aspect of the participatory budget in Belo Horizonte that almost all interview respondents agreed was a major success. Marcos Santana, a former Socialist Party politician claimed: 
People who used to have unfulfilled demands now know that they have an avenue for having them attended to.

Clarice Barreto Linhaus stated that one of the participatory budget's main successes was:

An inversion of priorities; the most needy bairros [suburbs] now receive the most resources. Previously city resources were distributed to the most well off and politically powerful. Now they go to the most needy.

Maria Auxiliadora Gomes, stated that:

Through the participatory budget, works have been approved for which people have been waiting many, many years.

Gilma Carmélia Alves claimed that:

Prior to the participatory budget there had been some public works that the public had waited 30 years or 50 years to see undertaken.

While there is much less empirical data available for Belo Horizonte than exists for Porto Alegre, there is still enough to indicate that these claims are justified. Prior to the participatory budget in Belo Horizonte very little money was spent on new investments in lower income neighbourhoods (Paixão Bretas 1996). Now, as Avritzer (1998, p. 29) shows, on average, 25 percent of the money allocated to the participatory budget has been spent on investments in vilas and favelas $^{20}$. This percentage seems to be increasing as well: 64 out of the 114 works (56 percent) approved in the 2003/04 participatory budget were undertaken in low socio-economic areas (Prefeitura de Porto Alegre 2004, p. 13).

One piece of empirical evidence does seem to suggest that the improvements have been somewhat limited though. The results of a survey done by Avritzer (2002c, p. 1) show that 60.3 percent of community groups he surveyed now have access to public goods through the participatory budget, compared to 49.3 percent who claimed to have access prior to the participatory budget. This is still a fairly significant improvement, especially taking into

${ }^{20}$ In the vernacular of Belo Horizonte a vila is a very poor neighbourhood, while a favela is a slum. 
account the fact that most communities who had access to goods prior to the participatory budget achieved this through clientelistic practices, however, it could be argued that the improvement falls short of being a complete transformation.

Also, the same point needs to be made here that I made in Chapter 6: it is possible that the improvements in the provision of municipal services that occurred in Belo Horizonte would have occurred without the participatory budget simply by virtue of the reforming nature of the PT. Participatory budgeting did facilitate improvements in municipal services in Belo Horizonte, but it may not be the only way that this could have been achieved.

\subsubsection{Opening a Space for the Political Participation of the Previously Excluded}

As with Porto Alegre, the level of participation in the participatory budget in Belo Horizonte can be seen as a success, albeit a qualified one. Figure 7.3 (below) shows the number of participants in the budget process. In absolute terms these numbers are quite high - peaking at 43,350 in the 2001/02 round (Prefeitura de Belo Horizonte 2004, p. 7). However, as a percentage of the total population, the number of participants is low (approximately 2 percent). Also, unlike Porto Alegre where there was a fairly steady increase in participation, participation in Belo Horizonte has fluctuated considerably. Avritzer (2000) explains that this is the result of several factors. Firstly, participation started off at a relatively high level in Belo Horizonte because people there already knew about the successful process in Porto Alegre, and so were inclined to believe, from the start, that participation would bring benefits. Secondly, he argues, participation dropped in 1998 and 1999 in the lead up to the municipal elections where it was unclear, thanks to the splitting of the 'Frente Popular' in the previous elections, whether either the PT or any other political party sympathetic to the participatory budget would win power. Avritzer believes that this doubt had an adverse effect on participation because potential participants thought that if an anti-participatory budget candidate won power they would discontinue the process, meaning that demands made would go unmet. 


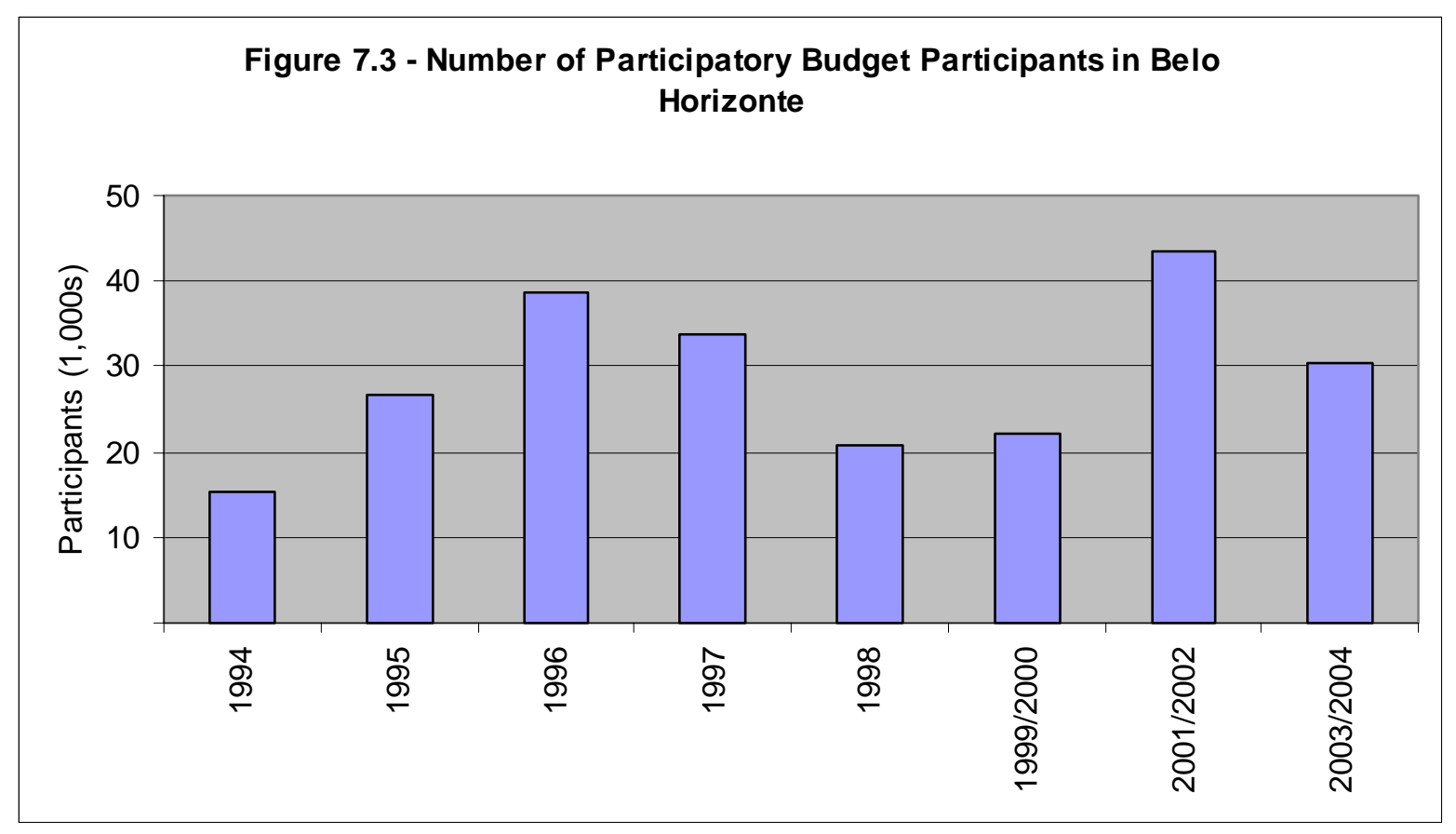

Source: Prefeitura de Belo Horizonte 2004, p. 7

With regards to the type of person who participates, most interviewees claimed that the participatory budget had opened up a space for the previously excluded. Marcos Santana stated:

The poor, they feel and realise that they can and must participate in the government decisions.

Clarice Barreto Linhaus said that:

The history of Brazil has been one of very limited popular participation and popular involvement in the democratic process; the participatory budget represents a significant change in this.

Empirical evidence appears to back up these claims. Table 7.1 shows the income breakdown of participants taken from a survey conducted in 2003. 
Table 7.1 - Breakdown of Participatory Budget Participants by Family Income

\begin{tabular}{|c|c|}
\hline Family Income & Percentage of Respondents \\
\hline Receives no income & $0.96 \%$ \\
\hline $0-2$ times the minimum wage & $24.92 \%$ \\
\hline $2-5$ times the minimum wage & $39.94 \%$ \\
\hline $5-10$ times the minimum wage & $15.34 \%$ \\
\hline $10-20$ times the minimum wage & $8.63 \%$ \\
\hline $20+$ & $1.92 \%$ \\
\hline No response & $8.31 \%$ \\
\hline
\end{tabular}

Source: Prefeitura de Belo Horizonte 2004, p. 50

Because the minimum wage is set very low in Brazil it is reasonable to consider five times the minimum wage as a cut off line between working class and middle class. This means that 64.8 percent of the participants surveyed came from lower socio-economic groups; a significant transformation given that politics in Belo Horizonte have historically been dominated very strongly by a small, very wealthy elite (Hagopian 1996) ${ }^{21}$.

\subsubsection{Reduced Clientelism}

Several interviewees as well as much of the literature on Belo Horizonte (see for example Avritzer 1998) cite reduced clientelism as a success of the participatory budget in the city. This is backed up by the empirical evidence of Avritzer's (2002c, p. 1) survey on community groups which shows that the number of community groups who claimed to utilise the "intervention of politicians" to obtain access to public goods dropped significantly after the introduction of the participatory budget. It is worth noting however, that Avritzer's survey also shows that clientelistic practices do still occur in Belo Horizonte (7.3 percent of groups he surveyed claimed that they still utilised the "intervention of politicians" to obtain access to public goods). Souza (2001) agrees with Avritzer on this and offers as a possible explanation the fact that 50 percent of Belo Horizonte's investment budget is still allocated in a non-participatory manner, which leaves scope for clientelism to continue.

\footnotetext{
${ }^{21}$ The same survey, cited above, also showed that the gender breakdown of participants was relatively equitable: 52 percent were men and 47 percent were women (one percent did not respond to the question).
} 


\subsubsection{Reduced Corruption}

As I noted in Chapter 6 on Porto Alegre, claims of reduced corruption are difficult to test empirically. However, as in Porto Alegre, there seems reasonable cause to believe that the participatory budget has reduced corruption in Belo Horizonte. Especially given the fact that the Comforça, which is made up of ordinary citizens from different parts of the city, plays a very active role in monitoring the implementation of participatory budget projects.

Several interviewees mentioned reduced corruption as a success; Paula Romanelli Simões' comment on this was typical of what was claimed:

Previously [before the participatory budget] no one knew what was scheduled to be constructed or what was going on. The new system is much more open.

Along similar lines, Maria da Paixão Dias stated that:

Before, politicians did not initiate public works for the public good but for their own political or personal gain. The participatory budget has changed this.

\subsubsection{Public Satisfaction}

As I mentioned in the previous chapter, being popular is not strictly a 'success' for the participatory budget; in reality, it is a measure of success. However, the fact that the process is or is not popular does help validate other claims of success.

In the case of Belo Horizonte, Souza (2001, p. 170) cites a 1994 survey in which 67.3 percent of respondents approved of the participatory budget. This was the highest level of approval for any government policy at the time. More recent empirical data is hard to come by. A 2003 survey of participatory budget participants (Prefeitura de Belo Horizonte 2004) asked respondents about a variety of aspects of the participatory budget and their responses were overwhelmingly favourable. However, the usefulness of this survey is limited by the fact that people critical of the participatory budget would be highly unlikely to be participants and therefore will not have taken part in the survey. 


\subsection{Problems and Limitations}

The following sub-chapter describes three things. Firstly, it details the external problems that have hindered the implementation and undertaking of the participatory budget in Belo Horizonte. Then it describes the problems of the participatory budget itself - what has gone wrong internally. Finally, some of the limitations of the participatory budgeting process are highlighted.

\subsubsection{External Problem - Resistance from Government Departments}

A problem experienced, initially, by the participatory budget in Belo Horizonte was resistance from SUDECAP, the agency in charge of public works in the city. SUDECAP was, according to Souza (2001, p. 170), "a powerful agency...[which] had strong links to the building industry." As such, and because of the fact that any project approved by the participatory budget would have to pass through it, the agency was in a real position to hinder the operation of the budgeting process. However, after some initial troubles, Patrus Ananias solved the problem by replacing the agency's existing board of directors with a new board that was much more amenable to the participatory budget (Souza 2001).

\subsubsection{External Problem - Resistance from Elites}

An ongoing problem that the participatory budget has experienced in Belo Horizonte has been resistance from the city's political and economic elites. This resistance has taken the form of hostile reporting in some local newspapers and also resistance from some politicians. Along these lines Roberto Rocha Coelho Pires stated in his interview that:

Resistance from elites - both politicians and others - has been a problem. They do not like the fact that it diminishes their power.

It is important to note though, that while elite resistance has existed in Belo Horizonte it has never been as strong as in Porto Alegre. I discuss the reasons for this in Chapter 8 .

\subsubsection{Internal Problem - Inadequate Staffing Levels}

Initially, as I described in Sub-Chapter 7.6, the participatory budget was co-ordinated by a section of the mayor's office and only four or five people were allocated to this coordination process. As Gilma Carmélia Alves dos Santos noted: 
Three people were not enough to undertake this co-ordination so there were lots of difficulties and problems in the initial phases of the participatory budget.

This, in turn, led to delays as Roberto Rocha Coelho Pires, explained:

They did not have the capacity to process all the demands, so there were delays.

\subsubsection{Internal and External Problem - Completing Works On Time}

Even with more staff, completing projects on time remained a problem in Belo Horizonte. The conservative councillor who I interviewed in Belo Horizonte told me that:

Works that were approved four years ago still have not been completed.

Ongoing delays seem to have been a result of two factors: first, the inherent problems associated with undertaking municipal works; and second, the bureaucratic public tendering process required for municipal works in Belo Horizonte. As Rodrigo Barroso Fernandes stated:

One reason for the delays is that we are legally required to tender-out the works. So because of the bureaucratic process, works take a long time to complete.

A partial solution to this problem of delays was the changing of the participatory budget process to a two yearly system (Roberto Rocha Coelho Pires, interview notes). This appears to have alleviated the problem to a degree and, while delays still occur, it is important to remember Rebecca Abers' comment from the previous chapter:

You know what, before the participatory budget in Porto Alegre and Belo Horizonte, budgets were not itemised so nobody even knew what was scheduled to go ahead that year. There could not be any delays because there were not any deadlines. 


\subsubsection{Internal Problem - Reaching the Sub-Poor and the Middle Classes}

One significant ongoing problem that the participatory budget has encountered has been low participation rates from the middle classes in Belo Horizonte. Low middle class participation is thought to have been a result of the fact that most of the middle class's most pressing needs have been met, as well as the fact that they have other political tools available for obtaining what they require. In his interview, Rodrigo Barroso Fernandes stated that:

Within Belo Horizonte the class that participates the least is the middle class, because their needs are met.

While Marcos Santana claimed:

The participatory budget has failed to reach out to the people with fewer needs. The less needy have fewer motives to participate because they have other options.

Although none of my interviewees mentioned it, I also believe that another plausible reason for low middle class participation in the participatory budget is that, traditionally the middle classes have been hostile to the PT in Belo Horizonte (as opposed to Porto Alegre where the PT receives significant middle class support.) In his interview, Marcelo Kunrath Silva discussed this with relation to Porto Alegre:

In Porto Alegre the PT is a party of the middle class (doctors, engineers etc). In other states the PT is a party of the working class - the middle class does not support it. The PT only really became a popular 'working class' party in Porto Alegre after it had shown by example that it could benefit the poor with the participatory budget.

There also appears to have been a self-perpetuating component to low middle class participation in Belo Horizonte. Because middle class neighbourhoods started off with relatively low levels of participation they have had trouble obtaining works and so there has been less incentive to participate in subsequent budgets. As Maria da Paixão Dias notes: 
Until 2001 it was very difficult to get anything done for our road [which had a drainage problem] because we were part of Regão Leste [Eastern Region]. We are part of one of the better neighbourhoods in Regão Leste and so were competing against favelas and other much more needy areas for participatory budget money.

The change that Maria talks about in 2001 was the re-districting of the participatory budgeting process in Belo Horizonte. With this re-districting, budget districts were designed to become more economically homogeneous and a special sub-region was created for the middle class neighbourhoods (even those that were not adjacent to each other) as part of an attempt to encourage their participation. Gilma Carmélia Alves dos Santos stated in her interview that:

Generally poorer neighbourhoods participate more; it is the middle class that is difficult to get involved. For this region we created a special sub-region - grouping middle class bairros together - so that they would have better access to the process.

I was unable to obtain any empirical data to ascertain whether municipality efforts to encourage middle class participation have been successful or not, although Table 7.1 appears to show that higher socio-economic groups are not completely avoiding the participatory budget, and are now participating in reasonable numbers.

Along with poor middle class participation levels, many interviewees identified an additional problem: low levels of participation amongst Belo Horizonte's most marginalized groups. In Belo Horizonte the poor participated at relatively high levels, however, the poorest segment of the poor did not participate nearly so much. Discussing the problems experienced by the participatory budget Paula Romanelli Simões stated that "the under-classes have low levels of participation as well."

Rodrigo Barroso Fernandes concurred with this in his interview:

The poor participate a lot - but not the sub poor - they are not aware that they have the right. 
As with low middle class participation, the city government has tried to rectify the problem of low levels of participation from the sub-poor as well.

Gilma Carmélia Alves dos Santos stated that:

We help the poorest neighbourhoods get organised in various ways; for example we assist in transporting people to meetings and we advertise meetings in advance by driving a loudspeaker car around advertising the upcoming event.

The city government has also established the housing forum (as part of the participatory budget) to cater to the needs of the city's homeless or vulnerably accommodated (Prefeitura de Belo Horizonte n.d.). As well as this they have established priority areas which receive higher weightings when it comes to the allocation of budget monies. As Rodrigo Barroso Fernandes stated:

The city is trying to incentivise these people to participate so more resources are directed to their neighbourhoods.

At present there is no empirical evidence to enable an assessment of how successful the city's attempts have been at resolving this problem.

\subsubsection{Problem/Limitation - Land Tenure}

A further problem/limitation to befall the participatory budgeting process in Belo Horizonte has been the same issue of land legalisation that caused problems in Porto Alegre. The city hall is limited in what sort of work it can undertake on land that is illegally occupied. As Paula Romanelli Simões noted, "land ownership issues have caused us significant problems in the past."

\subsubsection{Limitation - Belo Horizonte is Still a Third World City}

Although no interviewees raised this issue, from what I observed of Belo Horizonte's sprawling favelas and social problems, I am inclined to believe that the participatory budget there shares an additional common limitation with the process in Porto Alegre. This is the fact that it is a process dealing with new investments at a city level, in a large third world country, beset with problems much larger than any city can solve. There is only so much that the participatory budget can achieve in these circumstances. This does 
not mean that the process is of no merit by any means, but it does mean that it has its limitations.

\subsection{Uncertainties}

\subsubsection{How Much Power is Really Divulged?}

One significant question that has been asked about the participatory budget in Belo Horizonte is whether it divulges as much power as it could to participants. Only 50 percent of the city's new-investment budget is allocated through the process (as opposed to 100 percent in Porto Alegre). And, while there is the city-wide Housing Budget, the participatory budget in Belo Horizonte does not have the parallel thematic processes that run alongside the regional process in Porto Alegre. Marcos Santana stated that:

The participatory budget only deals with localised demands and is only a small percentage of the total budget.

The conservative councillor I interviewed made a similar point:

The proportion of the total city budget that is decided through the participatory budget is tiny, less than 2.5 percent.

In reality, the participatory budget does not receive less than 2.5 percent of the overall budget; in a typical year it receives 2.5 - 3 percent of the total budget as Clarice Barreto Linhaus pointed out.

Five to six percent of the total city budget is given over to investments and only 50 percent of this is given to the participatory budget.

The justification given by the city hall for withholding the other 50 percent is that it needs to make executive decisions about large-scale city-wide projects. Theoretically the people of Belo Horizonte have some say in how this other 50 percent is spent via the "city conference' that takes place every few years, however, this conference is only consultative and as Clarice Barreto Linhaus stated, "probably has not been functioning that well".

Furthermore, as opposed to Porto Alegre where the participants - via the Budget Council can determine many of the rules of how the participatory budget is run, the system in Belo 
Horizonte does not provide a mechanism that enables participants to choose how the process will be operated (Prefeitura de Belo Horizonte n.d.; Prefeitura de Porto Alegre 2004).

It is important to note that these criticisms do not mean that participation in Belo Horizonte is a sham. Unlike other Brazilian experiences such as Porto Alegre under Collares (discussed in Abers 2000) and Recife (examined in Wampler 2002), where city governments engaged in 'consultations' with the public and then ignored the proposals put forth, the space opened up for participation in Belo Horizonte is genuine. If the public selects a project - and it is technically viable - it goes ahead. And this process has led to significant municipal works being undertaken in areas that have previously had no access to public goods. As Marcos Santana - who was critical of many aspects of the participatory budget - noted, "it is still much better than the system that existed previously."

The question then that remains to be answered in Belo Horizonte, is not, "is the participation genuine' or 'has participation helped the poor', but rather, 'has as much space as possible actually been opened up for participation'?

\subsubsection{Does the Caravan of Priorities Really Promote Altruism?}

Another question that remains unanswered is whether the 'Caravan of Priorities' phase of the participatory budget (this is where the delegates go and visit each of the proposed projects in their region) really encourages delegates to place the projects of more needy neighbourhoods ahead of their own when it comes to voting time. This is certainly the explicit purpose of the Caravan as Gilma Carmélia Alves noted:

The Caravan exists to make people aware that others have greater needs than they do. It exists to make people sensible enough to compromise.

However, Maria da Paixão Dias, argued that the Caravan process was:

Very difficult, people make exchanges, promises to vote for another neighbourhood's projects in exchange for a vote for their own. 
And when I asked Roberto Rocha Coelho Pires whether the Caravan worked or not he said:

Yes and no. Sometimes it encourages people to see beyond their own interests but often it degenerates into bargaining.

So it would appear that the Caravan of Priorities has had mixed results. How successful it has been is uncertain, as are the circumstances under which it might operate more effectively.

Rebecca Abers, who has not studied Belo Horizonte in detail, but who has spent some time there, had interesting analogous evidence to suggest that when other neighbourhoods' needs were particularly dire (for example, when poor drainage was causing houses to be flooded leading to higher levels of infant mortality) delegates did in fact 'open their hands' quite readily and vote against their own interests. However, when circumstances were not so dire the process was less effective. This is an interesting possibility that warrants further research.

\subsubsection{Manipulation}

Also uncertain in Belo Horizonte is the extent to which the participatory budgeting process is being manipulated or used in duplicitous ways. From my research it appears that there is certainly some manipulation taking place, with both politicians and regular citizens trying to use the participatory budget, in deceitful ways, to further their own ambitions (either political or material).

Maria da Paixão Dias claimed that:

Sometimes poorer neighbourhoods are manipulated by politicians who say, 'I will give you this basket of food if you go and vote for the proposal I want to go ahead.'

She also claimed that:

After our neighbourhood achieved a major mobilisation to obtain its health centre our mobilising power attracted the 
attention of the politicians who saw the potential to gain votes and so they tried to infiltrate our neighbourhood organisation.

Clarice Barreto Linhaus said she was aware of councillors:

Arranging buses to get people to participatory budget meetings to boost their [the councillors] popularity.

She also mentioned that community leaders "tried to subvert the process for their own gain." As well as this she stated that:

I can not prove this yet but I am suspicious that the people with power in the participatory budget are often the same people from year to year. They develop established positions for themselves.

So it appears that some forms of subversion of the participatory budget are taking place. The unresolved question is how prevalent this is and to what extent it undermines the process.

\subsubsection{Civil Society}

The final uncertainty about the participatory budget in Belo Horizonte relates to its effects on civil society. Clarice Barreto Linhaus claimed in her interview that one of the successes of the participatory budget has been "its role as a school of democracy".

Avritzer (1998, p. 20) discusses the neighbourhood of Zila Spósito as an example of how people learned how to participate:

They did not know how to claim and they failed to convince other participants on the priority of their claims. A change in the neighborhood association and the formation of a new leadership led them to envision a much better organized form of participation in the next year leading them to have their claims included in the city P.B. [participatory budget] plan for 1995. 
There can be little doubt that the participatory budget in Belo Horizonte has opened a space for non-elites to participate in the political process in the city. Likewise, there can be little doubt that this has enabled the previously excluded much better access to municipal works. However, it is unclear the degree to which all of this has created a new type of empowered political citizen. Souza (2001), for example, cites a survey undertaken by William Nylen which shows that the majority of the delegates in the participatory budget process were already active members in community organisations (i.e. they were already engaged in the political process as opposed to being unorganised and disenfranchised). Of course this one survey does not completely negate the transformative potential of the participatory budget. After all, it is only a survey of delegates rather than all participants and it does not invalidate the claim that poorly organised community organisations became better organised as a result of the participatory budget. However, it does suggest that the outcomes in this area are still unclear.

\subsection{Conclusions}

This chapter has provided an analysis of the participatory budget in Belo Horizonte. As in Porto Alegre, participatory budgeting in Belo Horizonte has had some significant successes while, at the same time encountering an array of obstacles that have hampered its progress. The main successes in Belo Horizonte are: improved provision of municipal services, a reduction in corruption and clientelism, and the opening of political space to non-elite groups. The main problems that it has encountered are: resistance from government bureaucrats, under staffing, delays in completing projects on time, issues with land tenure, and poor participation from the sub-poor and the middle classes.

Examining this list it becomes clear that there are both similarities and differences in the outcomes of participatory budgeting in Porto Alegre and Belo Horizonte. This fact has some important implications for any conclusions about the transferability of the participatory budgeting as well as for conclusions about which local factors are particularly important in determining the outcomes of the participatory budget. In the following chapter I proceed to analyse and compare results for both Porto Alegre and Belo Horizonte. This analysis then leads into conclusions about the factors that can influence the outcomes of the participatory budget in different locations. 


\section{Chapter 8 - Analysis, Comparison and Discussion}

\subsection{Introduction}

The previous two chapters of this dissertation have presented the results of my research on the participatory budget in Porto Alegre and Belo Horizonte; including the local context that the participatory budgets have taken place within as well as the budgets' successes, the problems that have befallen the processes, and the areas where outcomes have been uncertain. This chapter now provides a comparison of the two cities' experiences with participatory budgeting. The comparison then leads into the second half of the chapter, where I identify a set of key variables - which may vary from location to location, or even change within the same location over a period of time - that influence the outcomes of participatory budgeting.

\subsection{Comparing the Context}

The first characteristic that Porto Alegre and Belo Horizonte share is the fact that both cities are located in Brazil. While, this may appear to be stating the painfully obvious, it is still an important point to make. Even though Porto Alegre and Belo Horizonte are different cities, located in different parts of the country, neither city has managed to escape from the incredibly in-egalitarian distribution of wealth and power that has characterised Brazil's history and which continues up until the present. While there are differences in the political history and political cultures of the two cities (these are discussed below), they share with each other, and with the rest of the country, important characteristics such as: a history of political corruption, a tradition of clientelistic electioneering, and the ongoing problems of a large disenfranchised urban underclass. This point is significant for two reasons. Firstly, it should be taken into account when considering the applicability of participatory budgeting to cities outside of Brazil. Secondly, as I noted in both Chapters 7 and 8, when assessing the results and limitations of the participatory budgeting process, observers ought to remind themselves that there is only so much that can be achieved at the city-level. The sweeping changes that would be required to really eradicate social problems in Brazil will have to take place on a national (and possibly even international) scale.

Amongst the differences that do exist between Porto Alegre and Belo Horizonte is the fact that Porto Alegre is a wealthier, more egalitarian city with a higher HDI than Belo 
Horizonte. The comparative social and economic statistics for the two cities are shown in Table 8.1 (below).

\section{Table 8.1 - Comparative Social and Economic Statistics for Porto Alegre and Belo Horizonte}

\begin{tabular}{|l|c|c|}
\hline \multicolumn{1}{|c|}{ Index } & Porto Alegre & Belo Horizonte \\
\hline HDI - 2000 & 0.865 & 0.839 \\
\hline Per- Capital income - 2000 (PPPU) & 710 & 557 \\
\hline Gini Coefficient - 2000 & 0.61 & 0.62 \\
\hline
\end{tabular}

Source: UNDP Brazil 2000

While the difference in distribution of wealth (Gini Coefficient) between the two cities is insignificant, income levels in Porto Alegre are considerably higher. Porto Alegre also has a higher HDI than Belo Horizonte. Belo Horizonte is a significantly larger city having a population of 2,238,526, in the year 2000, compared to Porto Alegre's population of $1,320,739$ in the same year (UNDP Brazil 2000).

With regards to the political history/political culture of the cities, although neither city has been immune to the elite domination of politics typical of Brazil, nor the associated problems of clientelism and corruption, there are still some significant differences between them. In particular, politics in Belo Horizonte has traditionally been dominated by a small conservative oligarchy (Hagopian 1996) while, on the other hand, politics in Porto Alegre has a history of populist / centre left politicians (Abers 2000).

At a neighbourhood level, Porto Alegre has had a much longer history of community organising than Belo Horizonte. While, historically, many neighbourhood organisations in Porto Alegre operated in a clientelistic manner, this began to change during the dictatorship years with a new breed of combative civic activists emerging (Abers 2000). Even before the participatory budget was introduced in Porto Alegre, a majority of community organisations surveyed by Avritzer (2002c) were using social mobilisation rather than clientelism to obtain public goods (a significant minority were still relying on clientelism though). Prior to the military dictatorship in Belo Horizonte, neighbourhood organising was much less prevalent. However, a dramatic rise in neighbourhood organisations took place in Belo Horizonte during the dictatorship years. While, prior to the participatory budget many of these organisations were combative, the majority of them relied on clientelistic practices to obtain public goods (Avritzer 2002). In other 
words, Belo Horizonte's history of community organising is shorter than Porto Alegre's and clientelism has been more prevalent there.

\subsection{Comparing the Processes}

While there are some differences in the way that the participatory budget is run in Porto Alegre and Belo Horizonte, the overall structure of the processes in both cities is relatively similar. Both processes contain elements of direct assembly-style democracy as well as elements of representative democracy. To overcome the dilemmas associated with the fact that direct democracy becomes unwieldy when involving large numbers of participants, both cities have engaged in a process of breaking the city up into administrative units that are small enough to allow assemblies to be practically viable. At the assembly level, participants in both cities vote on projects for their region as well as representatives (delegates) for the delegate fora. In Porto Alegre, participants also vote for representatives on the Budget Council and for spending priorities for their region. In Belo Horizonte however, it is the delegates who select the representatives of the Comforça (Belo Horizonte's equivalent of the Budget Council). In both cities it is the budget delegates who choose which projects will go ahead for a region, while it is the Budget Council in Porto Alegre and the Comforça in Belo Horizonte who work with the municipal government to turn the list of projects into a budget document. There is an inherently re-distributive component to the participatory budget in Porto Alegre and Belo Horizonte with both processes guaranteeing (through the formula that allocates money to different parts of the city) that poorer regions and sub-regions will receive a higher level of investment than they would if the budget was allocated on population size alone.

In both cities higher participation from sub-regions is rewarded by more delegates being elected to the delegates fora, which in turn increases the chance of a sub-regions' projects being voted for at that stage in the process.

In both cities, the participatory budget's history has been a reflexive one, with the process being adapted to overcome problems and to incorporate lessons learnt. Perhaps the most significant change to take place in Belo Horizonte has been the change to a two-yearly timeframe for the process. Porto Alegre, on the other hand, still operates the participatory budget over the period of a year.

In both Porto Alegre and Belo Horizonte the city hall has technical input into the budget process. However, municipal staff have significantly more input in Belo Horizonte than 
they do in Porto Alegre. In general, the participatory budget in Porto Alegre has opened a much larger space for participation than the participatory budget in Belo Horizonte has done. As discussed previously, only 50 percent of the new-investments budget is allocated through the participatory budget process in Belo Horizonte compared to 100 percent in Porto Alegre. With the exception of the city-wide housing budget and the irregular city conferences, the participatory budget in Belo Horizonte is limited to dealing with regional needs. In Porto Alegre, on the other hand, the Thematic Process gives participants input into decisions about investments that affect the city as a whole. In Porto Alegre the Budget Council also has a role in deciding the rules for the participatory budget, something that the Comforça does not do in Belo Horizonte.

\subsection{Comparing the Results}

\subsubsection{Provision of Services}

Most of the literature on the participatory budget in Porto Alegre and Belo Horizonte as well as most of the interviewees highlighted increased provision of municipal services, particularly to areas that have received very few of these services in the past, as one of the major successes of the process. The empirical evidence that I was able to obtain - there was more of this for Porto Alegre than Belo Horizonte - appears to confirm these claims.

\subsubsection{Participation}

Levels of participation in both cities were similar at around $1.5-2$ percent of the cities' population. The trends in participation differed between the two cities, however, with participation in Porto Alegre rising fairly steadily before starting to plateau, while participation in Belo Horizonte started higher and has fluctuated more. In both cities, surveys of participants showed that working class groups were the most common participants in the process, suggesting that the participatory budget had opened up a significant space for a sector of society that has traditionally been marginalized from the Brazilian political process. While working class participation was high in both cities, in Belo Horizonte several respondents mentioned that a significant problem for the process in that city had been difficulties including the sub-poor and the middle classes in the participatory budget. While none of the interviewees in Porto Alegre raised this issue, suggesting that it may not have been as acute there, it is worth noting that some of the literature (see for example Abers 2000) states that middle class participation, in particular, in Porto Alegre had been relatively low, and that this has been problematic. 


\subsubsection{Corruption and Clientelism}

While there was little empirical data to test this claim, there seemed to be a reasonable consensus amongst both interviewees and the literature that the participatory budget had reduced corruption in both Porto Alegre and Belo Horizonte by increasing transparency. Along with reduced corruption, a reduction in clientelistic practices was cited in almost all of the literature as well as by many interviewees as a major success of the participatory budget in the two cities. A survey of community organisations undertaken by Avritzer (2002c, p. 1) seems to confirm these claims by showing a complete elimination of clientelistic practices in Porto Alegre and a significant reduction in clientelism in Belo Horizonte. The fact that some clientelism persists in Belo Horizonte appears to be the result of two factors. The first being that while clientelism was prevalent in Porto Alegre prior to the participatory budget, the process was even more strongly ingrained in Belo Horizonte. The second factor is that the participatory budget in Belo Horizonte only allocates 50 percent of the new investment budget for the city, leaving the remaining 50 percent potentially available for clientelistic exchange (Souza 2001).

\subsubsection{Popularity}

The empirical data that is available suggests that in both cities, while only a small percentage of the total population actually participates in the participatory budget process itself, a majority of citizens are aware of the participatory budget and approve of it.

\subsubsection{Success for the PT}

In Porto Alegre several respondents noted that the popularity of the participatory budget had an additional benefit: it had helped the PT have its mayoral candidates re-elected three times. This is a significant success given that (as I discussed extensively in Chapter 5) PT municipal governments have been very prone to being voted out of office after only one term in power. It is also important to note that every city in Brazil where the PT has managed to stay in power for a significant period of time has had some form of participatory budget operating. However, installing the participatory budget has not guaranteed re-election for the PT and there have been several cities where the PT has lost power despite implementing participatory budgets - the most notable of these being Belo Horizonte (see Nylen 2003 for examples of other cities where this has occurred). The case of the PT's 1996 election loss in Belo Horizonte does not completely invalidate the idea that the participatory budget does help the PT win re-election. For a start, the 1996 election in Belo Horizonte took place in extraordinary circumstances with the PT being split and the mayor bestowing his support to a candidate from another party. Furthermore, 
that candidate - Célio de Castro - had been vice mayor in the PT led coalition government and so was also associated with the participatory budget. Finally, the PT won elections in Belo Horizonte in 2000. When all these points are taken into account it seems reasonable to argue that the participatory budget has played some role in raising the PT's popularity in Belo Horizonte, but that this effect has limits and will not guarantee re-election, particularly when the party is confronted by a crisis such as a split over mayoral candidates.

\subsection{Comparing the Problems and Limitations}

\subsubsection{Completing Works on Time}

The task of completing works mandated by the participatory budget on time (or in time for the next budget year) has plagued both Porto Alegre and Belo Horizonte. In Belo Horizonte one consequence has been the changing of the participatory budget from a oneyear to a two-year cycle. While delays in getting projects completed on time does represent a problem, it is important to note that there is no evidence that that participatory budget itself makes it any harder to expedite project completion; other limitations such as the contract tendering process - which would exist regardless of the participatory budget are the main cause of delay. Moreover, prior to participatory budgeting, budgets in both cities were non-programmatic, meaning that governments could not even be held to task over delays as the public had no idea what projects were actually scheduled to be undertaken or when they were due to be competed.

\subsubsection{Land-Ownership}

An external problem that hampered the participatory budget in both Porto Alegre and Belo Horizonte was the issue of land legalisation, or more specifically, the fact that the municipal governments of the two cities were limited in what services they could provide to areas where residents did not have legal title to the land.

\subsubsection{Resistance from Municipal Bureaucracy}

In Belo Horizonte the existing municipal bureaucracy provided a challenge for the participatory budget programme because they were reluctant to change their operational systems to accommodate the participatory budget. This problem was resolved by Patrus Ananias who fired the board of directors of the main planning department and replaced them with a new board comprising of members more agreeable to the participatory budget. While I did not encounter any evidence of bureaucratic resistance being a problem 
in Porto Alegre, Souza (2001) mentions, in passing, that trouble with the existing municipal bureaucracy was one of the factors that contributed to establishment of the GAPLAN department by the city hall. So it is possible that the same issue did exist in Porto Alegre to a degree.

\subsubsection{Lack of Money for New Investments}

A significant problem that occurred in Porto Alegre but which was not as significant in Belo Horizonte was lack of money available for new investments in the initial year of the participatory budget process. In Porto Alegre, the consequence of this was that almost none of the projects proposed by the first year's participants were undertaken. This, in turn, caused the participatory budget to lose a significant degree of credibility and participation levels went down. Only when new taxation revenues started flowing into city coffers, and participants started seeing tangible benefits arising from their participation, did the participatory budget recover and participation begin to rise.

\subsubsection{Lack of Staff}

The primary commodity that the participatory budget lacked in Belo Horizonte in its initial years was not money but staff, having only four or five people to organise the whole process. Comments made by several interviewees - who worked for the municipal government - indicated that, unsurprisingly, this shortage of staff was, until it was rectified, a significant hindrance to the operation of the participatory budget in Belo Horizonte.

\subsubsection{Lack of Technical Input and Centralised Planning}

While Porto Alegre did not suffer from inadequate staffing, some of the literature as well as some interviewees identified as a problem the fact that there was little technical assessment of the viability of proposed projects in the participatory budget's early years. This lack of technical input lead to problems with projects going ahead despite the fact that they were unfeasible, or lacking proper consideration of the flow-on effects from their construction. One interviewee - Sergio Baierle - argued that a lack of technical input or, at least, a concerted attempt to obtain a city-wide assessment of the consequences of projects, was still missing from the participatory budget process in Porto Alegre. A similar problem was not mentioned by any interviewees in Belo Horizonte or in any of the literature on Belo Horizonte. 


\subsubsection{Elite Resistance}

In both Porto Alegre and Belo Horizonte, the participatory budget process suffered from resistance from the cities' elites; however, the degree of resistance, particularly from city councillors, seems to have been significantly stronger in Porto Alegre. There appear to be several reasons for this. The first is the fact that the participatory budget is the flagship of the PT in Porto Alegre, whereas it is not so emblematic in Belo Horizonte and is presented more as part of a whole package of PT programmes. The second is that 50 percent of the new investments budget in Belo Horizonte is still distributed in a non-participatory manner, which would appear to leave space for clientelistic practices to continue. This means that the process represents less of challenge to the councillors' sphere of power, so they are less likely to resist it (Souza 2001). However, it is important to note that while elite resistance has been a problem in Porto Alegre, it still has not stopped the participatory budget from functioning, nor have a majority of councillors ever voted against the budgets that eventuate from the participatory process. Initially, the primary reason for this was - as far as I could ascertain - the fact that councillors were wary of voting against something that was seen as the public voice. In Porto Alegre, in recent years, councillor resistance has become less problematic for the participatory budget because the PT and allied parties are close to having a majority in the council and they already have enough councillors to stop their opponents from obtaining the two thirds majority vote necessary to override a mayoral veto (Marcelo Kunrath Silva, interview notes).

\subsubsection{Low Participation from Some Sectors of Society}

In both Porto Alegre and Belo Horizonte there was some evidence that middle class participation in the participatory budget was low and that the municipal councils in both cities had to intervene to raise levels of middle class participation. From the evidence available to me, this problem seemed worse in Belo Horizonte than Porto Alegre. The primary explanation for low middle class participation was that, as their most pressing needs for municipal services had been met, there was less incentive for them to participate.

In Belo Horizonte there were also problems with low levels of participation from the subpoor. Although I was given no satisfactory explanation as to why this problem occurred, I suspect that it was a result of there being few already existing organisational structures (such as neighbourhood organisations) amongst Belo Horizonte's least well off. 


\subsection{Uncertainties}

In both Porto Alegre and Belo Horizonte there are several important questions about the participatory budget for which answers remain elusive.

\subsubsection{Civil Society}

The first of these questions is what influence did the state of civil society prior to the participatory budget being introduced have on the outcomes of the process? The question remains difficult to answer clearly because, although civil society was more active in Porto Alegre than Belo Horizonte, the period of the military dictatorship had seen a considerable growth in civic organisations in Belo Horizonte as well, meaning that, in 1993, the city had an active civil society. Similarly, while clientelism was more deeply ingrained in Belo Horizonte than in Porto Alegre the problem also existed in Porto Alegre. The consequence of this is that it is difficult - from a study of these two cities alone - to draw any conclusions about how the state of civil society will influence participatory budgeting.

At the same time that the influence of civil society on the outcomes of the participatory budget in Porto Alegre and Belo Horizonte is unclear, it is also unclear what the effect of the participatory budget has been on civil society in the two cities. Evidence from both cities seems to suggest that the participatory budget has generated additional and/or reinvigorated existing civic activism (Abers 2000; Avritzer 1998). However, evidence from Porto Alegre appears to indicate that often the new activism is focused on short term goals (Wampler 2002), while evidence from Belo Horizonte indicates that many of the participants in the participatory budget there were already involved in neighbourhood organisations before the process started (Souza 2001). Yet, at the same time, participation in the thematic assemblies and city conferences in Porto Alegre suggests that not all participants are thinking only about short-term goals, while Avritzer's (2002c) research into the change in nature of Belo Horizonte residents associations since the participatory budget has been implemented suggests that even if participation is primarily limited to people already civilly active, they are at least operating in a less clientelistic manner. The results then, while providing tantalising suggestions about the effects of the participatory budget on civil society, are still unclear.

\subsubsection{Manipulation}

Another area that is unclear in both cities is how prone the participatory budgeting process is to being manipulated either by politicians or by other interested parties. Evidence from 
both cities suggests that manipulation takes place (although there is no evidence that the PT itself has been involved in manipulation). However, it is unclear whether the manipulation already significantly undermines the participatory budget, or, if it does not at present, whether it has the potential to do so in the future.

\subsubsection{How Much Power is Really Divulged in Belo Horizonte?}

A final area of uncertainty is whether the participatory budget in Belo Horizonte is really as participatory as it could be. In Belo Horizonte the city hall has much more influence through its technical evaluation of proposals. Also, the money available to the participatory budget in Belo Horizonte is only 50 percent of the new investments budget.

\subsection{What has Affected Outcomes?}

So what can be concluded from this analysis? The first obvious point is that - in light of the fact that participatory budgeting has been successful in Belo Horizonte - it can be concluded that participatory budgeting is not something that can only work in Porto Alegre. Moreover, while Porto Alegre and Belo Horizonte have similarities as cities they are not identical; Belo Horizonte is significantly larger and poorer than Porto Alegre, has a lower HDI and a more conservative political history. The fact that the participatory budget has succeeded in Belo Horizonte as well as Porto Alegre shows that it can succeed when placed in a different context. However, the similarities that exist between Porto Alegre and Belo Horizonte means that this conclusion needs to be qualified somewhat: success in Belo Horizonte does not mean that the participatory budget can operate in any context, but that it can operate in a variety of contexts, not just the Porto Alegrean one.

The second set of conclusions relates to the identification of a key set of variables that can affect the outcomes of the participatory budget when it is applied in different settings. In discussing these variables I have separated the variables into two different 'tiers'. First tier variables are those that can directly influence the outcomes of the participatory budget while second tier variables are those that will indirectly affect outcomes through their effects on the first tier variables (this is represented diagrammatically in Figure 8.1). The two first tier variables are: people having immediate needs, and the ability of the participatory budget to produce tangible results. The six second tier variables are: the amount of money available to the participatory budget; the external constraints and limitations it operates under; the organisation that implements the participatory budget; the political reality that constrains the organisation implementing the participatory budget; 
the city's economic status; and the equality with which the city's resources are distributed ${ }^{22}$.

\subsubsection{People Having Needs}

The first of the first tier variables that can be identified from my research is that people will participate more when they have immediate pressing needs. This is highlighted by the fact that participation in both cities is highest amongst the working classes, and also by Wampler's (2002) research showing that participants often ceased participating when their needs were met.

Many of my interviewees also made the claim that those with the most pressing needs participated most. Márcia da Silva Quadrado was typical of this when she stated that:

It is the people with the most needs who participate the most.

However, it is important to note when drawing this conclusion that while people with fewer needs do participate less, they still participate in the budget process - i.e. there was some middle and upper class participation in the participatory budget in both cities. It is also important to note that people, in both cities, participated in fora that were not purely based on attending to immediate needs (e.g. the City Conference). Finally, it should be noted that in Belo Horizonte there were problems with low rates amongst the city's least well off (the sub poor). As one would presume that the sub-poor would have the highest level needs, this would seem to indicate that other variables, such as the ability of communities to organise effectively, can override the effects of needyness. Indeed, all of the above caveats suggest that neediness does not operate independently of other variables in determining the outcomes of participatory budgeting. I discuss the interaction of variables later in this chapter.

\subsubsection{Factors that Influence the Level of People's Needs}

The Economic Status of a City and the Degree of Inequality of Resource Distribution in a City

\footnotetext{
${ }^{22}$ It could also be argued that the structure of the participatory budget itself should be included in this list of second tier variables, however, I believe that the budget's structure is actually a product of the other variables (i.e. it will be influenced by the ideology of the party that implements it etc.) rather than a separate variable. For this reason I have left it off the list.
} 
The two second tier variables that will influence the level of people's needs are: how wealthy a city is and how evenly a city's resources are distributed amongst its populace. In a wealthy city with an egalitarian distribution of wealth it is unlikely that many of the city's residents will have a major need for new municipal investments. However, in a poorer city or a city with a highly inegalitarian distribution of resources it is likely that a significant proportion of the population will live in areas in need of municipal investments.

\subsubsection{Tangible Results}

The second first tier variable that will affect the outcomes of participatory budgeting is the process's ability to produce tangible results. From comparing the early problems experienced by participatory budgeting in Porto Alegre with the less problematic start to participatory budgeting in Belo Horizonte, it becomes clear that participation will be much higher when people believe that there are tangible benefits that can be obtained from it. Marcelo Kunrath Silva's studies of Alvorada - a town neighbouring Porto Alegre - where participation fluctuated dramatically, corresponding to the city hall's ability to raise money for new investments, adds weight to this observation (Marcelo Kunrath Silva 2003). In his interview Marcelo expanded on this saying that:

Seventy percent of Alvorada's population works in Porto Alegre, so they already knew about the participatory budget. This means that there existed a high expectation from the people about the participatory budget and high levels of participation in the first year of the participatory budgeting process. But Alvorada had very few resources and so was unable to meet the people's promises. The consequence was that participation dropped. However, in a following year Alvorada received money from the state government and was able to undertake some works and so levels of participation increased again.

As well as Marcelo, many other interviewees made statements that back up this conclusion. Luis Alberto Giradi, stated that:

It would be a beautiful thing if I could claim that people supported the PT and the participatory budget for purely 
ideological reasons but, in reality, it is the results and the seeing to people's needs that gets the support.

\subsubsection{Factors which Influence the Participatory Budget's Ability to Produce Tangible Results}

Associated with the need for the participatory budget to produce tangible results are a variety of second tier variables which will influence the processes' ability to do this.

\section{Amount of Money}

The first of these is the amount of money made available to the participatory budgeting process. If the city government (or other organisation) implementing the participatory budget, can not/does not make enough money available to the project to enable it to produce tangible results, people will not participate. While this may seem like it is stating the obvious, there are numerous examples of cities in Brazil which have introduced participatory processes when they have not had the ability to devote money to them (such as Alvorada or Porto Alegre in the first year of the PT's programme there) or when they have not had the intention of devoting money to them (such as Recife and Porto Alegre under Collares). Moreover, a risk exists - even for a government genuinely committed to the participatory budget and which has run it successfully in the past - that changing external conditions (discussed below) may diminish the amount of money available to the participatory budget and reduce its credibility. As I discussed in Chapter 6, it is possible that this is occurring at present in Porto Alegre.

\section{External Constraints and Limitations}

As I have just discussed, the participatory budget needs money to produce results, and while the availability of money to the process is in part a result of factors specific to the city that it is operating in (i.e. commitment of the municipal government to the process and the local tax base), there are also external factors which will influence the amount of money available. An example of an external factor is the state of the economy (a domestic recession was a factor cited by interviewees in Porto Alegre that had reduced money available to the participatory budget). Another example is decisions made by state governments and the federal government about tax revenue transfers to municipal administrations. As outlined in Chapter 5, state governments hostile to PT municipal governments have diverted revenues away from their cities (this has not happened to Porto Alegre or Belo Horizonte, but it did occur to Belém which is operating a participatory budget (Guidry \& Petit 2003)). And, as I mentioned in Chapter 6, Cardoso's 
gradual re-centralisation has been a factor in the reduction of money available to participatory budgets.

An additional external constraint is the legal framework that the participatory budget has to operate within. In both Porto Alegre and Belo Horizonte, the participatory budgeting process has been constrained to a degree by the fact that, in Brazil, municipalities cannot provide services to settlements built on illegally occupied land.

\section{Who Implements the Participatory Budget?}

The next variable which will affect the budget's ability to produce tangible results is the political party (or other agent) responsible for introducing the process. As the experience of Brazilian cities shows, politicians are quite often willing to introduce consultative programmes that appear to be participatory but in reality divest little or no power to participants. Much less common are politicians who are interested in genuinely handing over power to people taking part in participatory processes. However, unless a real space is opened up to participation, participants are highly unlikely to see tangible results from their participation. Therefore, we can conclude that the nature of the political party - in particular how genuinely they are committed to participation - will be an important variable in determining the outcomes of participatory budgeting processes. In Brazil the PT has shown itself to be the political party with the most dedication to introducing genuinely participatory processes. Yet the experience in Belo Horizonte, where the participatory budget was successfully run for four years under a mayor from a different political party, shows that the participatory budget can operate under the rule of other political parties. However, it is worth noting that Célio de Castro came from a political party of a similar political persuasion to the PT, and that he and the PT patched up their differences after he won the elections, meaning that the PT had some input in the way he ran his administration ${ }^{23}$.

Political parties themselves are not homogenous entities either - especially in a country as large as Brazil - and from the results of my research, it seems reasonable to conclude that the nature of the local party is also another factor that will influence the participatory budget, in particular the way it is structured. In Belo Horizonte the participatory budget is noticeably less participatory than in Porto Alegre; while an element of this was probably a

\footnotetext{
${ }^{23}$ The experience of Curitiba where a non-PT mayor successfully introduced some participatory programmes also suggests that participatory budgeting does not have to be tied to the PT.
} 
concession to Belo Horizonte's more conservative political culture, several respondents argued that the main reason that the participatory budget was less participatory in Belo Horizonte was because the PT in Belo Horizonte held more moderate beliefs about the values of participation.

\section{The Political Reality that Constrains the Party Introducing the Participatory Budget}

In addition to the nature of the political party introducing the participatory budget, the political reality it is operating in is another significant factor that will influence the outcomes of the participatory budget. As discussed in Chapter 5, PT municipal governments have been confronted by a variety of dilemmas and problems when they have taken power in Brazilian cities. While, in some cases the participatory budget has aided the PT in overcoming some of the problems they have faced (Abers 2000), in others the problems have seen the PT voted out of power after only one term, meaning that the participatory budget has had very little time to produce any results (parties replacing the PT typically remove or reduce the power of the process when they get into power) (Baiocchi 2003; Gonçalves Couto 2003).

In Brazil in particular, the strength of resistance from political elites to the participatory budget is potentially a major problem as, even when the PT wins a mayoralty, existing political elites retain a significant degree of power through sympathetic media outlets, their business interests and non PT councillors. The one strong point that the participatory budget has in overcoming elite resistance is that councillors are often reluctant to vote against the participatory budget when they are asked to ratify it, because they are afraid of being seen as acting against the public voice.

\section{City's Economic Status}

The wealth or poverty of a city will also be an important factor influencing whether the participatory budget can produce tangible results. If a city is too poor then it may simply not be able to obtain revenue to fund the process. As Marcelo Kunrath Silva stated during his interview when talking about Alvorada:

It is not possible to raise extra revenue like they did in Porto Alegre; there simply is not the tax base. 


\section{The Uncertain Role of Urban Political Culture, Civil Society}

Many of my interview respondents stated that they thought that cities' political culture and the nature of their civil society would have an effect on the outcomes of the participatory budget. In particular, many interviewees argued that the participatory budget would be more difficult to implement or would have more limited results in cities which had less history of political activism or civic organising. This would seem intuitive and would also seem to be confirmed by the results of Kunrath Silva's (2003) work on Alvorada and Gravataí as well as the problem of low levels of participation amongst the sub-poor in Belo Horizonte. However, it is also important to note that Abers' (2000) work on neighbourhoods with very little organising history in Porto Alegre show that, in some circumstances, the participatory budget is able to generate a culture of participation (albeit an imperfect one). Furthermore, in Belém - a city in Brazil's north-east where, traditionally, politics has been strongly exclusive of lower socio-economic groups and where organisation of these groups has been very weak - a participatory budget programme has been in place for seven years and has obtained levels of participation higher than those in Porto Alegre and Belo Horizonte (Guidry \& Petit 2003). At this stage there is little evidence about the quality of the participation in Belém or the other results of the process, however, the high levels of participation there do seem to suggest that the participatory budget can operate in a variety of different social, political and economic climates. As I have said before, the results in this area are unclear and further research is needed.

\subsection{Bringing it all Together, How the Variables Interact}

Clearly, none of the variables listed above operate in isolation; rather they are part of a complex interacting system where the positive effects of one factor might offset the negative effects of another. For example, a city government strongly committed to tax reform and also cutting other expenditures might be able to implement the process successfully even in a relatively poor city. Likewise, a political party strongly committed to fostering a participatory culture and educating the population might well be able to operate the participatory budget in a city with very little previous history of popular participation. At the same time, however, a government with the best of intentions may be thwarted in its attempts to implement the participatory budget if legal constraints are too numerous or if hostility from political elites is too strong. The potential interaction between the variables that I have outlined is shown below in Figure 8.1. 
Figure 8.1 - Interaction of Key Variables in Participatory Budgeting Process

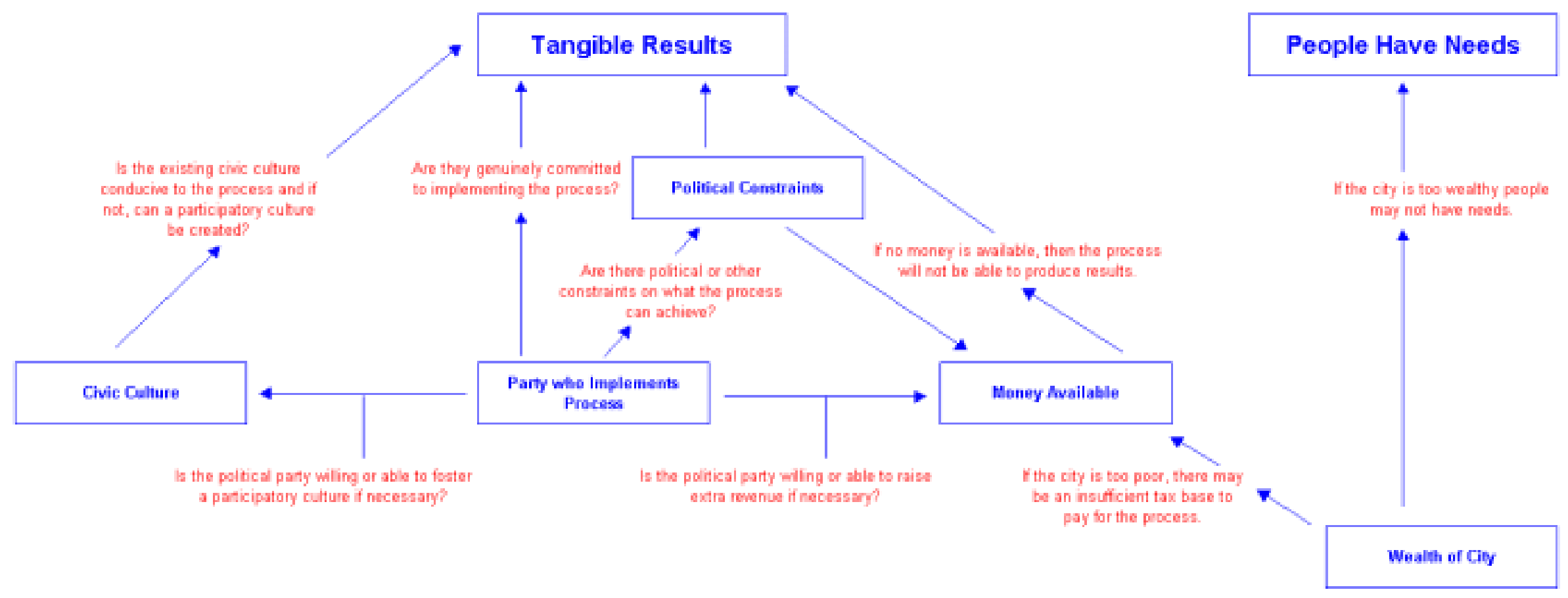

Source: My own fieldwork 


\subsection{Conclusion}

From looking at Figure 8.1 it becomes clear that success is not a forgone conclusion when a participatory budget is implemented. Instead there are a variety of variables that can influence the outcomes of the participatory budgeting either directly or via other variables. This is an important point which should be kept in mind both when designing participatory budgeting programmes and when assessing their performance. Understanding the role of local conditions when designing participatory budgeting programmes is important for the obvious reason that it can be used to inform their design. For example, if designers are aware that the area they are implementing participatory budgeting in has very little history of civic organising they could, potentially, design the process so that the city hall plays a particularly proactive role in fostering community participation. Likewise if designers are aware that most of the basic infrastructure needs are already met in a city, they could, potentially, re-formulate the participatory budget so that it focused on other areas such as the development of parks or civic cultural activities. With regards to assessing the performance of participatory budgets, it important to keep the role of local conditions in mind because they will invariably have an influence on the processes outcomes. Noting this influence rather than simply stating that participatory budgeting simply 'succeeded' or 'failed' in an area will, in turn, help the ongoing reflexive development of Participatory Democracy. 


\section{Chapter 9 - Conclusions}

\subsection{Introduction}

In early 2004 I spent two months in the Brazilian cities of Porto Alegre and Belo Horizonte. During that period of time I interviewed 22 people (eight in Porto Alegre, 11 in Belo Horizonte and three elsewhere), and collected a wide variety of secondary data on the topic of participatory budgeting. This dissertation has presented the results of this research as well as my analysis of these results. In this, the concluding chapter, I summarise the dissertation's findings, aiming to tie together the different strands of my project, providing the reader with a series of conclusions about participatory budgeting. In addition to this summary, I also highlight the shortfalls of my study and suggest areas where future research should be undertaken.

\subsection{Successes, Problems and Limitations: Participatory Budgeting in Porto Alegre and Belo Horizonte}

The first conclusion about participatory budgeting that can be drawn from my research relates to the fact that participatory budgets have had similar successes in both Porto Alegre and Belo Horizonte. In both cities participatory budgets have brought about a major improvement in the provision of municipal services, particularly to lower socioeconomic areas. As well as this, in both Porto Alegre and Belo Horizonte, participatory budgets have also been successful in opening up a space for political participation for people from lower income groups. Moreover, in both cities, participatory budgeting has been successful in reducing both clientelism and corruption, although the reduction in clientelism was less dramatic in Belo Horizonte. These successes took place despite the fact that there are notable differences between the two cities. In particular, Belo Horizonte is a larger, poorer city than Porto Alegre and has a stronger history of conservative politics; it also has a lesser, though still significant, tradition of neighbourhood activism than Porto Alegre. Because the participatory budget produced similar, positive outcomes in both cities, despite their differences, it can be concluded that participatory budgeting can produce favourable results in a variety of local conditions, not only those encountered in Porto Alegre.

As well as highlighting the successes of participatory budgeting, my research also uncovered areas where the process had experienced problems or limitations; in some cases these were common to both cities, in others only one city was affected. In both 
cities the process was hampered by hostility from local elites, hostility from existing bureaucrats, and issues of land ownership. In Porto Alegre, in the early years of the participatory budget, and again more recently, the participatory budget has encountered problems because of limited money available for new investments. Another problem in Porto Alegre was a lack of technical input into the participatory budgeting process (particularly in its early years), which led to impractical projects being approved. In Belo Horizonte the participatory budgeting process was hampered by having too few staff allocated to it. In both Porto Alegre and Belo Horizonte there were problems with getting public works requested via the participatory budget completed on time.

Given these problems and limitations, the next significant conclusion that can be made is that participatory budgeting is not, as a process, completely impervious to the local conditions. While it can produce successes in a variety of different settings, the results of participatory budgeting processes will be affected by a set of key variables that may change between locations.

\subsection{Highlighting the Key Variables}

I was able to identify some of these key variables. I also categorised the variables into two separate 'tiers'. Those variables that I deemed 'first tier' were those that directly affected participatory budgets' outcomes, while 'second tier' variables indirectly affected the outcomes of the participatory budget through their effects on first tier variables.

I identified two key first tier variables. The first was the ability of the participatory budget to produce tangible results to 'reward' participants for their participation. The second was the extent to which a city's populace 'needed' new municipal investments.

Influencing the first tier variables were four second tier variables. The second tier variables were: the amount of money available to the participatory budget; any external constraints (such as legal problems) that affect how the participatory budget is operated; the political party (or other agent) implementing the participatory budget; the political reality that this political party (or other agent) is forced to operate within; how wealthy the city is; and the equality with which existing municipal services are distributed in the city. 


\subsection{The Significance of Participatory Budgeting in the Brazilian Context}

As demonstrated in Chapter 4, elite domination of politics, at both the national and the regional level, has proven to be remarkably resilient in Brazil, having survived from colonial times, through the monarchy as well as republican periods and two dictatorial epochs. Since the early 1980s Brazil has undergone a period of re-democratisation, yet this political transformation has still not put an end to the elite stranglehold on the country's politics, nor has it put an end to the incredibly in-egalitarian distribution of wealth in Brazil. What has happened though, is that the country has seen the first truly significant challenge to this elite domination through the rise of the PT, culminating in the election of the PT's candidate to the presidency of Brazil in October 2002. Yet as the troubles that have befallen the PT since that election win have shown, in a country like Brazil, holding the executive office only offers so much space for effecting change. As described in Chapter 5, the limited scope for executive office holders to implement genuine reforms has not only thwarted the PT at a national level but has also been extremely problematic for PT municipal governments.

Set amongst the backdrop of Brazil's political culture and the troubles faced by the PT in municipal government, the successes of the participatory budget are even more significant. Clientelism and corruption have been endemic to Brazilian politics, yet in both Porto Alegre and Belo Horizonte, in a relatively short period of time, participatory budgeting has dramatically reduced their prevalence. Moreover, the troubles experienced by the PT show that, even when political power is obtained, reform is still very difficult. In Porto Alegre and Belo Horizonte participatory budgeting has been able to produce results despite these difficulties.

\subsection{The Significance of Participatory Budgeting for Democratic Theory and Development Theory}

The prevailing political culture in Brazil, the limitations of democracy there, and the successes of participatory budgeting also have important consequences for the debates about participation and democratic theory. In particular, the Brazilian case seems to refute Schumpeter's claim (discussed in Chapter 3) that participation in democracy should be limited to choosing between competing sets of ruling elites. When they get a chance to compete in Brazil, the country's elites do not compete fairly nor has their competition produced optimal outcomes for their constituents. On the other hand, the experience of participatory budgeting in Porto Alegre and Belo Horizonte shows that processes which increase the avenues for participation in democracy (attempts at creating 
Participatory Democracy) can facilitate better governance and produce tangible benefits for the previously marginalized ${ }^{24}$.

Porto Alegre and Belo Horizonte's participatory budgets are examples of a very pragmatic approach to Participatory Democracy, one that uses a mixture of direct democracy and representative democracy to offer people a more direct say in decisions that affect their communities. In this process direct Athenian style democracy is facilitated via decentralisation - the cities are broken up into units small enough that assemblies can be held. Representative democracy is then used to take decisions made via these assemblies, prioritise them and then create a new investments budget for the city.

The results of my research show that this pragmatic approach to Participatory Democracy has clearly been a success from an instrumental perspective: the increased opportunity for participation has produced tangible, material improvements. The results are less clear as to whether Participatory Democracy has been a success from the developmental perspective - whether it has created a better more informed type of civic citizen, although there is some evidence from both Porto Alegre and Belo Horizonte that this has occurred to a degree.

With respect to Development theory, the results of the participatory budgets in Porto Alegre and Belo Horizonte reinforce the case for participatory development. In both cities increased space for participation has facilitated improved outcomes, particularly for the poor. While this participation has been in the democratic process rather than in development projects, it seems reasonable to argue that participatory budgeting still provides a clear illustration of the general benefits of popular participation.

The participatory budgets of Porto Alegre and Belo Horizonte also provide an example of a pragmatic compromise between the extremes of 'participants know what is best for them' and 'only technical experts are capable of making decisions'. In both cities there is participant and technical expert input into the design of projects.

\footnotetext{
${ }^{24}$ An important caveat to this claim is the fact that, while participatory budgeting seems to have provided tanigble benefits to most of the previously marginalised, the still appears to exist an underclass of the cities' poorest who remain excluded from the benefits of the process.
} 


\subsection{The Limitations of this Research and Suggestions for Future Research}

When making these conclusions it is important to bear in mind that there are several important limitations to the research that I have undertaken, as well as areas where more research is needed.

The first limitation is that I have not compared Porto Alegre and Belo Horizonte with any other cities where the participatory budget has not been in operation. Until this comparison is made it is not possible to draw any conclusions about the performance of participatory budgeting in relation to any other programmes aimed at producing social change that may be in operation in Brazil. While it might seem a relatively easy task to undertake a cross-city comparison, either by using changes in HDI levels for cities, or by using some of the other indices that the UNDP Brazil collect, in reality such comparisons are complicated by the fact that many Brazilian cities do not count favela and informal settlement dwellers in their social statistics (Novak 2002). Marcelo Kunrath Silva in his interview advised me that the World Bank in conjunction with a team of Brazilian Academics is currently undertaking a detailed study analysing social and economic change in several Brazilian cities, some of which operate participatory budgets and others which do not. Research in this area will be important, and if the World Bank study on its own is not sufficient, more research ought to be undertaken to compare the effectiveness of the participatory budget with other Brazilian municipal programmes.

A second limitation of this study is that, while there are some significant differences between Porto Alegre and Belo Horizonte, they still have much in common (both cities for example are relatively large and neither city falls into the poorest tier of Brazilian cities). There are other Brazilian cities operating participatory budgeting processes which are more significantly different from Porto Alegre than Belo Horizonte was. I chose Belo Horizonte because the participatory budget has been operating there for a significant period of time. However, when participatory budget programmes in other Brazilian cities have been in place for longer periods, these cities should also be studied to broaden the understanding of how the participatory budget can operate in different conditions. Belém, located in Brazil's north is a dramatically different city from Porto Alegre and Belo Horizonte, and participatory budgeting has been in operation there for almost seven years. For these reasons I recommend that the participatory budget in Belém should be the focus of more study. 
A final limitation of this study is that it took place entirely in Brazil. As knowledge of participatory budgeting spreads it seems inevitable that it will be tried in other countries (indeed forms of participatory budgeting are already in place in some other Latin American cities) and, for a more complete understanding of participatory budgeting to be obtained, the process will need to be studied in detail in these other countries.

As well as those areas where I have identified the need for additional research as a result of the limitations of my own study, there is one further aspect of participatory budgeting that needs significantly more research. This is the interaction between civil society, political structures and the participatory budget. In particular, how do existing organisational and political structures impact on the outcomes of the participatory budget, and how does the participatory budget change existing organisational and political structures? While these areas have already been studied to some degree, and while several Brazilian academics are undertaking further research on this, it seems to me that much more work needs to be done here before a full picture of the interactions that take place between the participatory budget, and political and cultural systems can be properly understood.

My final suggestion for additional research relates to the fact that municipal elections are due to be held in Brazil in October/November 2004 (shortly after this dissertation is submitted). These elections will prove to be another test of the PT and of the participatory budget especially as Brazil is still in the midst of an economic downturn and the PT's credibility has suffered to a degree from the problems experienced by Lula as president. It will be interesting to see what becomes of the participatory budget in Brazilian cities after these elections.

\subsection{Final Remarks}

Writing on participatory budgeting in Brazil, Celina Souza (2001, p. 165) stated that "participation is certainly no panacea, nor is it an easy task, as the cases of Porto Alegre and Belo Horizonte show." My own research confirms this statement. Participatory budgeting in Porto Alegre and Belo Horizonte has not solved all of the problems of these cities, nor have its successes come easily. Yet, at the same time, participatory budgeting has clearly brought about positive changes, and these changes are even more dramatic when they are placed in the context of the clientelistic and corrupt practices that have dominated municipal politics in Brazil. Obviously, the successes of participatory budgeting are significant for the residents of Porto Alegre and Belo Horizonte who have 
benefited directly from them, and likewise, the successes are also important for the PT and its attempts to assail the Brazilian political elites. However, I would contend that the successes of participatory budgeting in Porto Alegre and Belo Horizonte extend beyond the purely practical sphere, and that these successes offer some very useful insights into how alternatives to conventional representative democracy might be developed. 


\section{References}

Abers, R. 1998, 'From Clientelism to Cooperation: Local Government, Participatory Policy, and Civic Organizing in Porto Alegre, Brazil', Politics \& Society, vol. 26, no. 4, pp. 511-539.

Abers, R. 2000, Inventing Local Democracy: Grass Roots Politics in Brazil, Lynne Rienner Publishers, Colorado.

Albert, M. 2003, Parecon: Life After Capitalism, W. W. Norton and Company, New York.

Avritzer, L. 1998, 'Public deliberation at the local level: participatory budgeting in Brazil', Experiments for Deliberative Democracy Conference, Wisconsin.

Avritzer, L. 2000, Civil Society, Public Space and Local Power: a study of the Participatory Budget in Belo Horizonte and Porto Alegre, Civil Society and Governance Programme, Institute of Development Studies, University of Sussex, [Online] 28 July 2004, Available at: http://www.ids.ac.uk/ids/civsoc/final /brazil/brz2.doc

Avritzer, L. 2002, Democracy and the Public Space in Latin America, Princeton University Press, New Jersey.

Avritzer, L. 2002(b), Participatory Budgeting in Porto Alegre, [Online] 28 July 2004, Available at: http://www.democraciaparticipativa.org/English/Arquivos/op_poa egl.htm

Avritzer, L. 2002(c), New Public Spheres in Brazil: Local Democracy and Deliberative Politics, [Online] 28 July 2004, Available at: http://www.democraciaparticipativa .org/English/Arquivos/avritzer_newpbspheres.htm

Baierle, S. 2002, 'The Brazilian Experience with the Participatory Budget: the Case of Porto Alegre' in Municipal Finance and Participatory Budgeting, ed., E. Mancuso, Municipal Government of Porto Alegre, Porto Alegre.

Baierle, S. 2003, 'The Porto Alegre Thermidor? Brazil's 'Participatory Budget' at the Crossroads', Socialist Register 2003: Fighting Identities: Race, Religion And Ethno-Nationalism, eds., L. Panitch \& C. Leys, Merlin Press, London.

Baiocchi, G. 2003, 'Radicals in Power' in Radicals in Power: The Workers' Party (PT) and experiments in Urban Democracy in Brazil, ed., G. Baiocchi, Zed Books, London.

Barber, B. 1984, Strong Democracy: Participatory Politics for a New Age, University of California Press, Berkeley.

Bellos, A. 2000, 'Kickbacks Scandal Hits Brazilian President', The Guardian, July 15, 2000.

Bhatnagar, B., Kanungo, P., Rathore, A. \& Moreno Torres, M. 2003, Participatory Budgeting in Brazil, World Bank, [Online] 20 August 2004, Available at: http://poverty.worldbank.org/files/14657Partic-Budg-Brazil-web.pdf 
Bradford Burns, E. 1980, A History of Brazil (Second Edition), Columbia University Press, New York.

Branford, S \& Kucinski, B. 2003, Politics Transformed: Lula and the Workers' Party in Brazil, Latin American Bureau, London.

Brockington, D. \& Sullivan, S. 2003, 'Qualitative Research' in Development Fieldwork, eds., R. Scheyvens \& D. Story, Sage Publications, London.

Brohman, J. 1996, Popular Development: Rethinking the Theory and Practice of Development, Blackwell Publishers, Oxford.

Cabannes, Y. 2004, 'Participatory Budgeting: A Significant Contribution to Participatory Democracy', Environment \& Urbanization, vol. 16, no. 1, pp. 27-46.

Central Intelligence Agency. 2004, 'Brazil', CIA World Factbook, Central Intelligence Agency, [Online] 28 July 2004, Available at: http://www.cia.gov/cia/publications/ factbook/geos/br.html

Chambers, R. 1998, Whose Reality Counts: Putting the First Last ( $2^{\text {nd }}$ edition), ITDG Publishing, Rugby.

Chomsky, N. \& Herman, E.S. 1988, Manufacturing Consent: the Political Economy of the Mass Media, Pantheon Books, New York.

Cook, B. \& Kothari, U. 2001, Participation: the New Tyranny, Zed Books, London.

Costa, A \& Velho Cardone, P.T (eds). n.d., Porto Alegre, Prefeitura do Porto Alegre, Porto Alegre.

Crosby, A.W. 1986, Ecological Imperialism: The Biological Expansion of Europe, $900-$ 1900, Canto, Cambridge.

Dahl, R.A. 1989, Democracy and its Critics, Yale University Press, New Haven.

Dahl, R.A. 1998, On Democracy, Yale University Press, New Haven.

De Sousa Santos, B. 1998, 'Participatory Budgeting in Porto Alegre: Toward a Redistributive Democracy', Politics \& Society, vol. 26, iss. 4, pp. 461-482.

Do Canto, I. (ed) 2003, OP Primer, City of Porto Alegre - Co-ordinator of Social Communications, Porto Alegre.

Encyclopædia Britannica. 2004, 'Rio Grande do Sul', Encyclopadia Britannica Premium Service, [Online] 28 July 2004, Available at: http://www.britannica.com/eb/ $\underline{\text { article? } \mathrm{eu}=65384}$

Encyclopædia Britannica. 2004 (b), 'Porto Alegre', Encyclopaedia Britannica Premium Service, [Online] 28 July 2004, Available at: http://www.britannica.com/eb/ article?eu=62540

Encyclopædia Britannica. 2004 (c), 'Belo Horizonte', Encyclopaedia Britannica Premium Service, [Online] 9 August 2004, Available at: http://www.britannica.com/eb/ $\underline{\text { article? } \mathrm{eu}=15505}$ 
Encyclopædia Britannica. 2004 (d), 'Democracy', Encyclopæedia Britannica Premium Service, [Online] 9 August 2004, Available at: http://www.britannica.com/eb/ article?eu=30382

Fausto, B. 1999, A Concise History of Brazil, Cambridge University Press, Cambridge.

Feres Faria, C. 1996, Democratizando a Relação Entre o Poder Público Municipal e a Sociedade Civil:O Orçamento Participativo em Belo Horizonte, Dissertation for Universidade Federal de Minas Gerais, Belo Horizonte.

Friedman, T.L. 2000, The Lexus and the Olive Tree, Harper Collins Publishers, London .

Fung, E. \& Olin Wright, E. 2003, Deepening Democracy: Institutional Innovations in Empowered Participatory Governance, Verso, London.

Goldfrank, B. 2003, 'Making Participation Work in Porto Alegre' in Radicals in Power: The Workers' Party (PT) and experiments in Urban Democracy in Brazil, ed., G. Baiocchi, Zed Books, London.

Gonçalves Couto, C. 2003, 'The Second Time Around: Marta Suplicity's PT Administration in São Paulo' in Radicals in Power: The Workers' Party (PT) and experiments in Urban Democracy in Brazil, ed., G. Baiocchi, Zed Books, London.

Groves, J. \& Robinson, D. 1998, Introducing Philosophy, Icon Books, Cambridge.

Guidry, J.A. \& Petit, P. 2003, 'Faith in What Will Change: The PT Administration in Belém' in Radicals in Power: The Workers' Party (PT) and experiments in Urban Democracy in Brazil, ed., G. Baiocchi, Zed Books, London.

Hagopian, F. 1996, Traditional Politics and Regime Change in Brazil, Cambridge University Press, Cambridge.

Hall, S. 2004, 'Only 51\% plan to vote in elections', The Guardian, March 25, 2004.

Hancock, G. 1989, Lords of Poverty: The Power, Prestige, and Corruption of the International Aid Business, Atlantic Monthly Press, New York.

Keck, M.E. 1992, The Workers Party and Democratization in Brazil, Yale University Press, New Haven.

Jacques, M. 2004, 'Democracy is not working', The Guardian, June 22, 2004.

Johnston, R.J., Gregory, D., Pratt, G. \& Watts, M. (eds) 2000, The Dictionary of Human Geography (4 ${ }^{\text {th }}$ Edition), Blackwell Publishers, Oxford.

Kapoor, I. 2002, 'The devil's in the theory: a critical assessment of Robert Chambers' work on participatory development', Third World Quarterly, vol. 23, no. 1, pp 101117.

Kitchin, R. \& Tate, N. 2000, Conducting Research in Human Geography: Theory Methodology and Practice, Prentice Hall, Harlow. 
Kunrath Silva, M. 2003, 'Participation by Design: The Experiences of Alvorada and Gravataí, Rio Grande do Sul, Brazil' in Radicals in Power: The Workers' Party (PT) and Experiments in Urban Democracy in Brazil, ed., G. Baiocchi, Zed Books, London.

Leslie, H \& Storey, D. 2003, 'Entering the Field' in Development Fieldwork, eds., R. Scheyvens \& D. Story, Sage Publications, London.

London School of Economics. 2004, 'Definition of civil society', [Online] 8 November 2004, Available at: http://www.lse.ac.uk/collections/CCS/introduction.htm

Martins, L \& Milton Schneider, R. 2004, 'Brazil', Encyclopadia Britannica Premium Service, [Online] 28 July 2004, Available at: http://www.britannica.com/eb/ $\underline{\text { article? eu }=108683}$

Mayo, H. B. 1960, An Introduction to Democratic Theory, Oxford University Press, Oxford.

Menegat, R. 2002, 'Participatory democracy and sustainable development: integrated urban environmental management in Porto Alegre, Brazil', Environment \& Urbanisation, vol. 14, no. 2, pp. 181-206.

Monbiot, G. 2004, The Age of Consent (Text of lecture given to the Royal Society of Arts), [Online] 26 August 2004, Available at: http://www.monbiot.com/archives/ 2004/08/18/the-age-of-consent/

Munk, D. 2003, 'Lula's Dreams for Brazil are delayed as the Realities of Power Hit Home', The Guardian, December 31, 2003.

Murray W.E. \& Overton, J. 2003, 'Designing Development Research' in Development Fieldwork, eds., R. Scheyvens \& D. Story, Sage Publications, London.

Navarro, Z. 1998, 'Participation, democratizing practices and the formation of a modern polity — the case of 'participatory budgeting' in Porto Alegre, Brazil (1989-1998)', Development, vol. 41, no. 3, pp. 68-71.

Novak, A. 2002, The Consequences of the Participatory Budget Process in Porto Alegre, Brazil for the Poor, A thesis for the Victory University Masters of Development Studies Programme.

Nylen, W. 1999, New Political Activists for Disillusioned Democracies: An Analysis of the Impact of 'Popular Participation' on Participants in the Participatory Budgets (Orçamento Participativos) of Betim \& Belo Horizonte, Minas Gerais, Brazil', Research Paper, Stetson University, Florida.

Nylen, W. 2003, 'An Enduring Legacy? Popular Participation in the Aftermath of the Participatory Budgets of João Monlevade and Betim' in Radicals in Power: The Workers' Party (PT) and Experiments in Urban Democracy in Brazil, ed., G. Baiocchi, Zed Books, London.

Overton, J. \& Van Dierman, P. 2003, 'Using Quantitative Techniques' in Development Fieldwork, eds., R. Scheyvens \& D. Story, Sage Publications, London. 
Oxfam Great Britain. n.d., The Brazilian Economic Crisis, [Online] 5 January 2004, Available at: http://www.oxfam.org.uk/what_we_do/issues/trade/ brazil_econcrisisfull.htm

Oxford English Dictionary Online. 2004, Clientelism, [Online] 26 August 2004, Available at: http://helicon.vuw.ac.nz:2126/cgi/entry/00316688? single=1 \&query_type $=$ word \&queryword=clientelism\&edition $=3 \mathrm{e} \&$ first $=1 \& \max$ to_show $=10$

Paixão Bretas, P.R. 1996, 'Participative Budgeting in Belo Horizonte: Democratization and Citizenship', Environment \&Urbanization, vol. 8, no. 1, pp. 213-221.

Palast, G. 1999. 'How the US seized power in Brazil', The Observer, March 7, 1999.

Parry, G. 1972, Participation in Politics, Manchester University Press, Manchester.

Pateman, C. 1970, Participation and Democratic Theory, Cambridge University Press, Cambridge.

Prefeitura de Belo Horizonte. 2003, OP 10 Anos, Prefeitura de Belo Horizonte, Belo Horizonte.

Prefeitura de Belo Horizonte. 2004, Plano regional de Empreendimentos Orçamento Participativo 2003/2004, Prefeitura de Belo Horizonte, Belo Horizonte.

Prefeitura de Belo Horizonte. n.d., Participatory Budget: 10 years of experience in Belo Horizonte, Prefeitura de Belo Horizonte, Belo Horizonte.

Prefeitura de Porto Alegre. 2004, Plano de investimentos e Serviços 2004, Prefeitura de Porto Alegre, Porto Alegre.

Prefeitura de Porto Alegre. 2004b, Participatory Budget Guidebook, Prefeitura de Porto Alegre, Porto Alegre.

Prefeitura de Porto Alegre. 2004c, Títulos e Conquistas: 16 anos de Administração Popular, Prefeitura de Porto Alegre, Porto Alegre.

Prezworski, A., Alvarez, M., Cheibub, J.A. \& Limorgi, F. 2000, Democracy and Development, Cambridge University Press, Cambridge.

Rocha Coelho Pires, R. 2001, Orçamento Participativo e Planejamento Municipal, Escola de Governo da Fundação João Pinheiro, Minas Gerais.

Sader, E. \& Silverstein, K. 1991, Without Fear of Being Happy: Lula, the Workers Party and Brazil, Verso, London.

Scheyvens, R., Nowak, B. \& Scheyvens, H. 2003, 'Ethical Issues' in Development Fieldwork, eds., R. Scheyvens \& D. Story, Sage Publications, London.

Sen, A. 1981, Poverty and Famines, Clarendon Press, Oxford.

Sen, A. 1999, Development as Freedom, Oxford University Press, Oxford. 
Shah, P. \& Wagle, S. 2003, 'Case Study 2 - Porto Alegre, Brazil: Participatory Approaches in Budgeting and Public Expenditure Management', World Bank Social Development Notes, Note No. 71, March 2003, pp. 1-4.

Skidmore, T.E. 1999, Brazil: Five Centuries of Change, Oxford University Press, Oxford.

Smith, J. 2002, A History of Brazil, Pearson Education, Harlow.

Sokoloff, K.L. \& Engerman, S.L. 2000, 'Institutions, factor Endowments, and Paths of Development in the New World', Journal of Economic Perspectives, vol. 14, no. 3 , pp. 217-232.

Souza, C. 2001, 'Participatory budgeting in Brazilian cities: limits and possibilities in building democratic institutions', Environment \& Urbanization, vol. 13, no. 1, pp. 159-184.

Stiglitz, J. 2002, Globalization and Its Discontents, Allen Lane / The Penguin Press, London.

Thompson, J. 1981, Critical Hermeneutics: A study in the thought of Paul Ricoeun and Jürgen Habermas, Cambridge University Press, Cambridge.

UNCHS. 1984, Community Participation in the Execution of Low Income Housing Projects, United Nations Centre for Human Settlements - HABITAT, Nairobi.

UNDP Brazil, 2000. New Atlas of Human Development in Brazil: 1991 - 2000, United Nations Development Programme Brazil, [Online] 3 August 2004, Available at: http://www.pnud.org.br/atlas/

Wade, R.H. 2003, The Invisible Hand of the American Empire, Open Democracy, [Online] 8 January 2004, Available at: http://www.opendemocracy.net/ debates/article-3-77-1038.jsp

Wainright, H. 2003, Reclaim the State, Verso, London.

Wampler, B. 2002, Private Executives, Legislative Brokers and Participatory Publics: Building Local Democracy in Brazil, [Online] 15 August 2004, Available at: www.democraciaparticipativa.org/ Arquivos/BrianWampler.pdf

World Bank. 2003, 'Case Study 2 - Porto Alegre, Brazil: Participatory Approaches in Budgeting and Public Expenditure Management', Social Development Notes, Note 71. [Online] 20 September 2003. Available at: http://www.worldbank.org/participation/sdn/snd71.pdf 


\section{Appendix 1 - Ethics Forms}

\section{Participant Information Sheet}

Researcher: Terence Wood, Development Studies Programme, School of Earth Sciences, Victoria University of Wellington, New Zealand

I am a Masters student studying Development Studies at Victoria University of Wellington. As part of my degree I am undertaking a research project leading to a thesis. My thesis research involves a study of the Participatory Budgeting process that is used in Porto Alegre and Belo Horizonte. As part of my research I will be interviewing yourself and other persons about the outcomes of the participatory budgeting process in these two cities.

The University requires that ethics approval be obtained for research involving people. The University also requires that I obtain your informed consent before undertaking this interview.

If you consent to this interview please be aware of the following points:

- The interview will take no more than 2 hours of your time.

- I will record the interview with a Dictaphone and, at a later date, have someone transcribe the interview to paper. At any stage in this interview you may ask for the Dictaphone to be turned off.

- I will store all Dictaphone tapes and interview transcriptions securely (in a locked room) for a year after my initial research is completed. No person other than myself and my supervisor (Dr Warwick Murray) will have access to the tapes or transcriptions. After this all tapes and interview notes will be destroyed.

- Your responses to my interview questions will become part of the body of research that I will publish in my thesis. The finished thesis will be viewed by two examiners (one from Victoria University and one from outside Victoria) it will also be available from Victoria University's library for students and other academic researchers to use. It is also possible that I will publish the results of my research in one or two scholarly journals and present them at academic conferences.

- You may withdraw yourself and your comments from this research process at any stage up to the final analysis is complete.

If you choose to consent to this interview, you have a choice as to whether you wish your responses to remain anonymous or not in any published research. If you choose the anonymous option then any comments you make will only be attributed in a general manner and will not be linked to your name or any other information that might identify you. If you choose not to remain anonymous then any statements you make may be attributed to you in the published research.

If you have any questions or would like to receive further information about the project, please contact me via email at woodtere@student.vuw.ac.nz or my supervisor, Dr Warwick Murray at the School of Earth Sciences at Victoria University, P O Box 600, email: Warwick.Murray@vuw.ac.nz 


\section{Participant Consent Form}

I have been given and have understood an explanation of this research project. I have had an opportunity to ask questions and have them answered to my satisfaction. I understand that I may withdraw myself (or any information I have provided) from this project (before data collection and analysis is complete) without having to give reasons or without penalty of any sort. I also understand that I may request the Dictaphone to be turned off at any stage during this interview.

I understand that tape recordings of any information I provide will be kept confidential to the researcher, the supervisor and the person who transcribes the tape recordings of our interview. I understand that tape recordings and transcriptions of this interview will be destroyed 1 year after this project is completed.

\section{Please Choose (by ticking the box from one of the following options)}

I only consent to undertaking this interview under the condition that the published results will not use my name, and that no opinions will be attributed to me in any way that will identify me

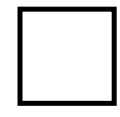

Or

I consent to information or opinions which I have given being attributed to me in any reports on this research.

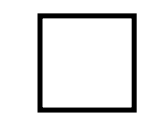

Please also indicate (by ticking in the box below) if you would like to receive a summary of the results of this research when it is completed.

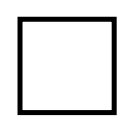

I agree to take part in this research

Signed:

Name of participant (please print clearly):

Date: 


\section{Participant Information Sheet - In Portuguese}

\section{Entrevistas sobre o Processo de Orçamento Participativo em Porto Alegre e Belo Horizonte}

Pesquisador Terence Wood, Programa de Estudos de Desenvolvimento, Escola de Ciências Terrestres, Universidade de Victoria em Wellington, Nova Zelândia.

Eu sou um aluno do curso de pos-graduação de Desenvolvimento de Estudos, na Universidade de Victoria, em Wellington e como parte de meu programa de estudos, estou desenvolvendo uma pesquisa para a conclusão de minha tese. Esta pesquisa envolve um estudo do processo de Orçamento Participativo, usado em Porto Alegre e em Belo Horizonte. Como parte de minha pesquisa, eu gostaria de entrevistar o senhor (a senhora) e outras pessoas sobre o Orçamento Participativo.

Para levar adiante uma pesquisa que envolve a participação de pessoas, primeiro é necessário ter a aprovação ética da Universidade. A Universidade também exige que eu obtenha o seu consentimento por escrito, antes de iniciar esta entrevista.

Se você concordar em ser entrevistado/a, por favor certifique-se dos seguintes detalhes:

A entrevista não vai tomar mais do que duas horas de seu tempo.

A entrevista será gravada e mais tarde alguém vai transcreve-la num documento. Durante a entrevista, você pode pedir que o gravador seja desligado.

As fitas gravadas e todas as anotações, serão guardadas em lugar seguro, por um ano após a conclusão de minha tese e depois serão destruídas. Ninguém alem de mim e de meu supervisor, Dr. Warwick Murray, terá acesso as fitas gravadas nem às anotações.

O que você disser durante a entrevista, fará parte de minha tese. Após concluída a tese, esta será corrigida por dois examinadores, sendo um deles da Universidade de Victoria.

A tese após concluída, estará disponível na biblioteca da Universidade de Victoria. Possivelmente, os resultados de minha pesquisa serão publicados nos Jornais Acadêmicos e também apresentada em conferencias acadêmicas.

Você pode pedir que seu nome e sua entrevista não façam parte desta tese, num prazo que vai ate a conclusão final dos trabalhos.

Se você concordar em ser entrevistado/a, pode escolher entre ter seu nome e sua entrevista divulgados nesta tese, ou ter sua entrevista divulgada, sem que seu nome seja citado.

Se você quiser mais informações sobre este projeto, por favor faça contato comigo, mandando um e- mail para woodtere@student.vuw.ac.nz ou com meu supervisor, Dr. Warvick Murray, no seguinte endereço: School of Earth Science of Victoria University, PO Box 600, Wellington, New Zealand. E-mail: Warwick.Murray@vuw.ac.nz .

Terence Wood 
Participant Consent Form - In Portuguese

\section{Entrevista sobre o Processo de Orçamento Participativo em Porto Alegre e Belo Horizonte}

Eu recebi e entendi a explicação sobre este projeto de pesquisa. Tive oportunidade de fazer perguntas sobre este Projeto e todas as explicações que recebi foram satisfatórias.

Estou ciente de que posso desistir de participar deste Projeto e posso pedir que todas as informações que forneci sejam canceladas, sem qualquer prejuízo para mim. Também posso pedir que o gravador seja desligado a qualquer momento durante a entrevista.

Estou ciente de que as gravações contendo as informações fornecidas por mim, serão guardadas em lugar seguro pelo pesquisador, pelo seu supervisor e pela pessoa que transcrever as gravações de minha entrevista.

Estou ciente de que as gravações de minha entrevista e as transcrições da mesma, serão destruídas um ano depois deste Projeto ser finalizado.

Por favor, escolha uma das opções abaixo, fazendo um X dentro de um dos boxes.

Eu concordo em fazer esta entrevista, somente com a condição de que o meu nome não seja citado nos resultados publicados.

\section{Ou}

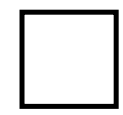

Eu dou consentimento para que as informações fornecidas por mim e as minhas opiniões sejam citadas em todos os relatórios desta pesquisa e que meu nome seja citado.

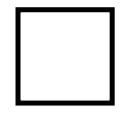

Por favor, faça um $\mathrm{X}$ no box abaixo se você quiser receber um resumo dos resultados desta pesquisa quando ela estiver finalizada.

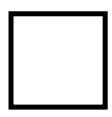

Eu concordo em fazer parte deste Projeto.

Assinado

Nome completo do participante de maneira legivel.

Data 
I agree that I will treat any information, opinions or comments that I become privy to as part of my transcribing / interpreting work on the research project of Terence Wood with complete confidentiality. I agree that I will not disclose any of this information to any third party in any form whatsoever.

Signed:

Name (please print clearly):

Date: 